HUMBERTO BERSANI

DIREITO DO TRABALHO NA MODERNIDADE LÍQUIDA SOB A PERSPECTIVA DOS DIREITOS HUMANOS

\author{
DISSERTAÇÃO DE MESTRADO \\ PROFESSOR ORIENTADOR \\ DENNIS DE OLIVEIRA
}

UNIVERSIDADE DE SÃO PAULO

SÃO PAULO 


\title{
DIREITO DO TRABALHO NA MODERNIDADE LÍQUIDA SOB A PERSPECTIVA DOS DIREITOS HUMANOS
}

\author{
DISSERTAÇÃO DE MESTRADO \\ PROFESSOR ORIENTADOR \\ DENNIS DE OLIVEIRA
}

Dissertação apresentada à banca examinadora da Faculdade de Direito da Universidade de São Paulo, como exigência parcial para a obtenção do título de mestre em Direitos Humanos, sob a orientação do Professor Doutor Dennis de Oliveira.

UNIVERSIDADE DE SÃO PAULO

SÃO PAULO 
BERSANI, Humberto

Direito do Trabalho na Modernidade Líquida sob a Perspectiva dos Direitos Humanos

Dissertação apresentada à banca examinadora da Faculdade de Direito da Universidade de São Paulo, como exigência parcial para a obtenção do título de mestre em Direitos Humanos, sob a orientação do Professor Doutor Dennis de Oliveira.

Aprovação em:

Banca examinadora

Prof(a). Dr(a).

Instituição Assinatura

Prof(a). Dr(a).

Instituição Assinatura

Prof(a). Dr(a).

Instituição Assinatura 
A ela, que perdeu a mãe aos nove anos, foi expulsa de casa pela madrasta e, então, teve de trabalhar na roça para se sustentar.

A ele, que perdeu o pai também aos nove anos, quando, então, teve de encarar o trabalho de engraxate para ajudar no sustento de sua família $e$, muitas vezes, após dizer que estava com fome, ouvia de sua mãe: "- Dorme, que passa!”

Aos dois, meus primeiros exemplos de vítimas da injustiça social consolidada no Brasil, maiores motivadores da minha investigação, trabalhadores incansáveis, admirados por tamanha sabedoria, humildade, amor e respeito... Aos meus pais, que ora representam os trabalhadores, dedico as minhas reflexões. 


\section{AGRADECIMENTOS}

Ao Professor Dennis, pela paciência, generosidade e confiança depositadas desde o início da orientação, pautada sempre pela humildade e vasta sabedoria.

À minha família, alicerce que me garantiu segurança durante todo o meu percurso, acompanhou minhas dificuldades, ouviu minhas lamentações, suportou as minhas angústias, mas sempre me apoiou e, se não tivesse exercido fundamental importância na minha trajetória, certamente não me seria possível conquistar este título.

A todos os meus amigos, pelo apoio e compreensão em face da minha distância, ocasionada pela obrigação de conciliar tantos afazeres desde o meu ingresso no Programa de Pós-Graduação.

Aos amigos reconhecidos durante o mestrado, que tornaram mais fácil minha permanência na Faculdade de Direito, na Escola de Comunicação e Artes e na Faculdade de Educação.

Aos professores com os quais travei contato durante o percurso realizado, a quem devo pelas lições que possibilitaram rever determinados caminhos outrora inquestionáveis no âmbito dos Direitos Humanos, bem como reafirmar outros.

À Professora Eunice Aparecida de Jesus Prudente que, aceitando prontamente o convite de participar do exame de qualificação, trouxe valiosas contribuições ao desenvolvimento da pesquisa.

Ao Professor Manoel Carlos Toledo Filho, grande defensor da humanização do Direito do Trabalho, pela colaboração, sinceridade e sugestões imprescindíveis à realização do estudo.

Aos colegas do Tribunal Regional do Trabalho da $15^{\text {a }}$ Região, especialmente à Elisa Mitsue Nakamura, bem como aos Doutores Lorival Ferreira dos Santos e Jorge Luiz Costa, pelo incentivo durante o período em que me dediquei às disciplinas e à pesquisa.

Marcondes, Maria Helena, Jaqueline, Jéssica, Matheus, Elaine, Sônia, Davi, Leonardo, Maria Beatriz, Georgia, Simone, Miriam, Juliana, Cristiano, Amanda, Ruben... Enfim, a todos aqueles que participaram, de alguma maneira, da minha trajetória até o momento, dos quais certamente trago algo e aos quais talvez algo eu tenha deixado, fica a minha gratidão. 
Quem construiu a Tebas de sete portas?

Nos livros estão nomes de reis.

Arrastaram eles os blocos de pedra?

E a Babilônia várias vezes destruída-

Quem a reconstruiu tantas vezes? Em que casas

Da Lima dourada moravam os construtores?

Para onde foram os pedreiros, na noite em que a Muralha da China ficou pronta?

A grande Roma está cheia de arcos do triunfo.

Quem os ergueu? Sobre quem

Triunfaram os Césares? A decantada Bizâncio

Tinha somente palácios para seus habitantes?

Mesmo na lendária Atlântida

Os que se afogavam gritaram por seus escravos

Na noite em que o mar a tragou.

O jovem Alexandre conquistou a Índia.

Sozinho?

César bateu os gauleses.

Não levava sequer um cozinheiro?

Filipe da Espanha chorou, quando sua Armada Naufragou. Ninguém mais chorou?

Frederico II venceu a Guerra dos Sete Anos.

Quem venceu além dele?

Cada página uma vitória.

Quem cozinhava o banquete?

A cada dez anos um grande homem.

Quem pagava a conta?

Tantas histórias.

Tantas questões. 


\section{RESUMO}

A pesquisa está relacionada ao estudo do Direito do Trabalho no contexto da chamada modernidade líquida, conceito proposto pelo sociólogo Zygmunt Bauman, partindo da perspectiva dos Direitos Humanos.

Assim, a investigação indaga a influência que a modernidade líquida exerce sobre o Direito do Trabalho como um todo, envolvendo desde as relações de trabalho até a atuação do Poder Judiciário, atingindo inclusive o problema da plena eficácia das garantias conferidas aos trabalhadores pelo ordenamento jurídico brasileiro como consequência do referido contexto.

Relativamente à perspectiva dos Direitos Humanos, o ponto de partida é a solidariedade como fundamento axiológico de tal seara de direitos, uma vez que o princípio influenciou o surgimento dos direitos sociais e, como o Direito do Trabalho integra aquele gênero, tal perspectiva será de grande valia.

Ademais, a questão dos direitos humanos também estará voltada à teoria sociológica de Bauman, observando seu olhar sobre tal gênero de direitos com consequente análise crítica do posicionamento por ele adotado.

Por fim, analisam-se os reflexos da modernidade líquida materializados no Direito do Trabalho, no âmbito da jurisprudência e em face da política conciliatória, de maneira que emerge a constatação da existência de um processo de desregulamentação da proteção aos trabalhadores com o auxílio do próprio Estado.

PALAVRAS-CHAVE: Direito do Trabalho; modernidade líquida; Direitos Humanos; Poder Judiciário. 


\begin{abstract}
This work is related to the Labor Law study in the context of called liquid modernity. This concept was proposed by the sociologist Zygmunt Bauman, from the perspective of Human Rights.

Thus, the purpose of this work is to investigate the influence of liquid modernity on Labor Law as a whole, from labor relations to the Judicial Power approaches. The study also includes the problem of rights full effectiveness guaranteed to workers by Brazilian law as a result of this context.

Regarding the perspective of Human Rights, the starting point is solidarity as the basis of such axiological harvest rights, since the principle has influenced the emergence of social rights and labor law as part of the genre, this perspective will be of great value.

Moreover, the issue of human rights will also be focused on the sociological theory of Bauman, investigating its point of view at this kind of rights with subsequent review of the position adopted.

Finally, we analyze the consequences of liquid modernity embodied in Labor Law, in the jurisprudence scope and facing the conciliatory politic, so giving rise to the finding of a deregulation of worker protection with their own State agreement.
\end{abstract}

KEY-WORDS: Labor Law; liquid modernity; Human Rights; Judicial Power. 


\section{LISTA DE SIGLAS}

CF - Constituição Federal

CLT - Consolidação das Leis do Trabalho

CNJ - Conselho Nacional de Justiça

DIEESE - Departamento Intersindical de Estatística e Estudos Socioeconômicos

ECA - Estatuto da Criança e do Adolescente

IBGE - Instituto Brasileiro de Geografia e Estatística

NR - Norma Regulamentadora

OIT - Organização Internacional do Trabalho

RR - Recurso de Revista

SDC - Seção de Dissídios Coletivos

SDI - Seção de Dissídios Individuais

SUS - Sistema Único de Saúde

TRT - Tribunal Regional do Trabalho

TST - Tribunal Superior do Trabalho

UNESCO - Organização das Nações Unidas para a Educação, a Ciência e a Cultura 


\section{SUMÁRIO}

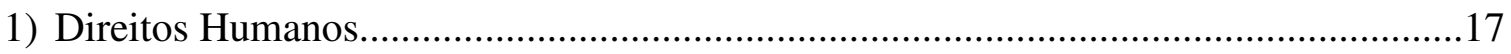

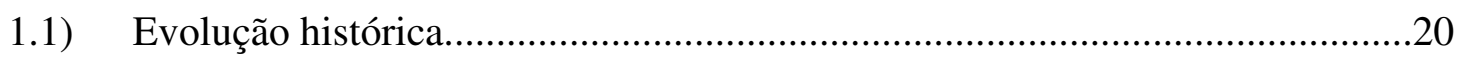

1.2) Gerações ou dimensões dos Direitos Humanos? ..............................................24

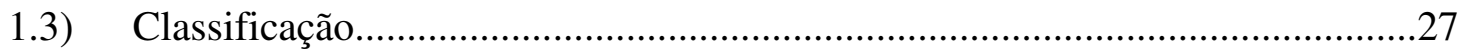

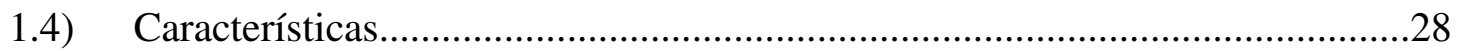

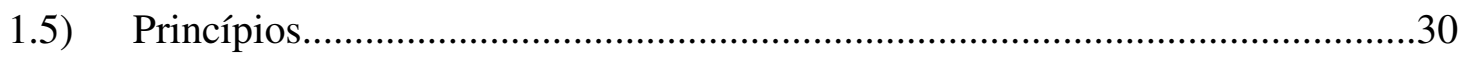

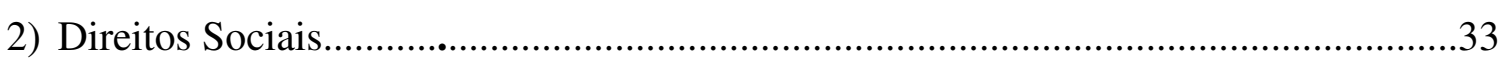

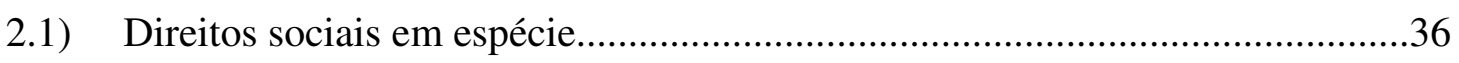

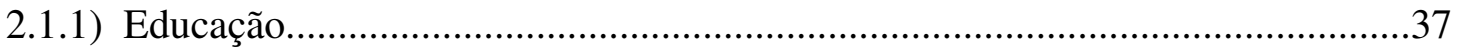

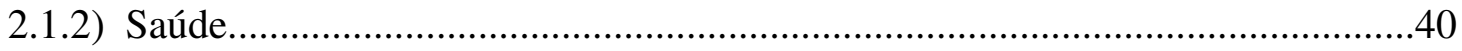

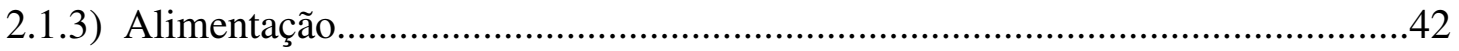

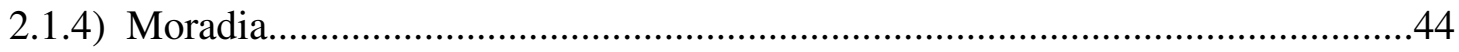

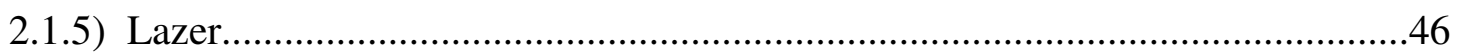

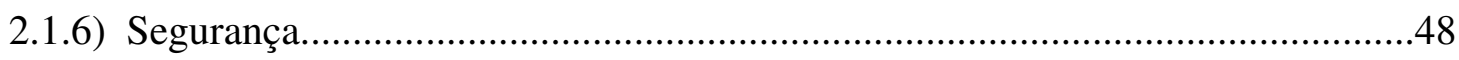

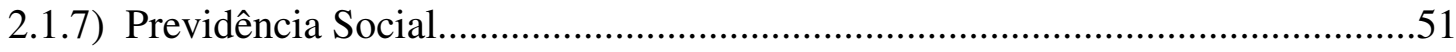

2.1.8) Proteção à maternidade e à infância...............................................................52

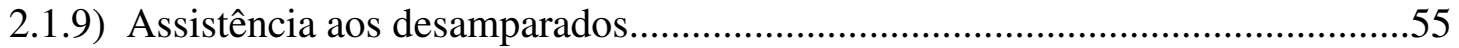

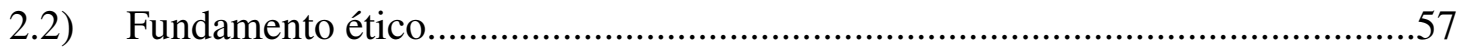

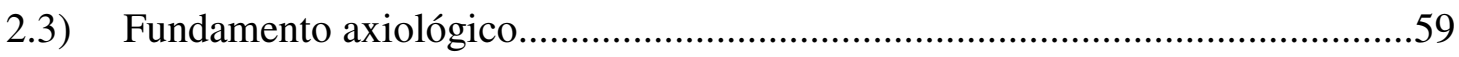

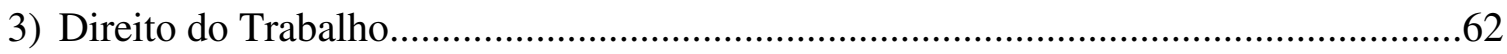

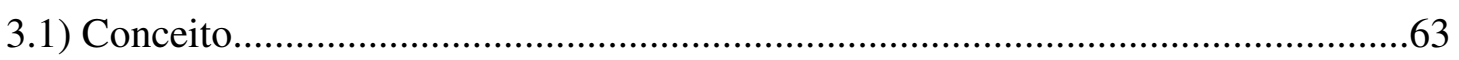

3.2) Evolução histórica no ordenamento jurídico brasileiro.........................................65

3.3) O trabalho como um direito social.......................................................................

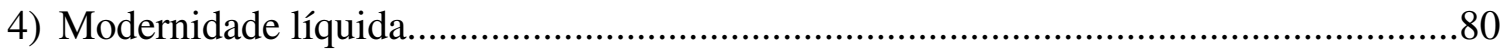

4.1) A proposta sociológica de Zygmunt Bauman.....................................................

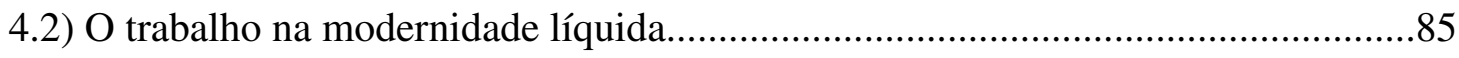

4.3) Sentido filosófico dos direitos humanos em Zygmunt Bauman............................88 
5) Modernidade líquida, Direito do Trabalho e o Poder Judiciário

5.1) Jurisprudência. .92

5.1.1) Renúncia nas negociações coletivas - o caso dos turnos ininterruptos de revezamento. .93

5.1.2) Os trabalhadores rurais... .97

5.1.3) O intervalo para refeição e descanso. 102

5.2) Conciliar é "legal"? 107

CONCLUSÕES... 113

REFERÊNCIAS BIBLIOGRÁFICAS. 116

ANEXOS. 


\section{INTRODUÇÃO}

A investigação do Direito do Trabalho enquanto conjunto normativo inserido no âmbito dos Direitos Humanos, sob o manto contextual da modernidade líquida, constitui um grande desafio. Esgotá-lo e delimitar todas as possibilidades de leitura corresponde, portanto, a um procedimento impossível numa única investigação.

Porém, dialogar com os investigadores de outros campos, relacionados direta ou indiretamente com o Direito do Trabalho, pode constituir um ponto de partida importante na busca de novos horizontes e sentidos para os inúmeros problemas decorrentes das relações laborais e da realidade vivenciada pelos trabalhadores submetidos ao ordenamento jurídico brasileiro.

Afinal, embora o ordenamento jurídico brasileiro contenha previsão expressa de direitos sociais, os quais foram elevados à categoria de norma constitucional, o Direito do Trabalho, ao envolver um dos integrantes do rol de tais direitos, tem sido objeto de violação cada vez maior pelos empregadores.

Vale lembrar que a expressão "direitos sociais" advém do princípio axiológico da solidariedade (ou fraternidade) ${ }^{1}$, entendido como:

A responsabilidade de todos pelas carências ou necessidades de qualquer indivíduo ou grupo social. (...) O fundamento ético desse princípio encontra-se na ideia de justiça distributiva, entendida como a necessária compensação de bens e vantagens entre as classes sociais, com a socialização dos riscos normais da existência humana ${ }^{2}$.

Com efeito, tal princípio constitui o sustentáculo para que se reconheçam, posteriormente, os direitos sociais propriamente ditos, englobando os direitos atinentes aos trabalhadores, bem assim a seguridade social, que inclui saúde, previdência e assistência social. Some-se, ainda, ao grupo ora mencionado, o direito à educação, moradia, consumidor e o próprio acesso à Justiça.

\footnotetext{
${ }^{1}$ Artigo $1^{\circ}$ da Declaração Universal dos Direitos Humanos: "Todos os homens nascem livres e iguais em dignidade e direitos. São dotados de razão e consciência e devem agir em relação uns aos outros com espírito de fraternidade".

${ }^{2}$ COMPARATO, Fábio Konder. A afirmação histórica dos direitos humanos. 6.ed. São Paulo: Saraiva, 2008. p. 65.
} 
O estudo do Direito do Trabalho, na ótica de leitura contextual ora proposta, requer a análise do pensamento sobre o trabalho proposto por Bauman, referencial teórico utilizado para buscar uma compreensão da realidade trabalhista brasileira. Segundo ele:

O trabalho adquiriu - ao lado de outras atividades da vida - uma significação principalmente estética. Espera-se que seja satisfatório por si mesmo e em si mesmo, e não mais medido pelos efeitos genuínos ou possíveis que traz a nossos semelhantes na humanidade ou ao poder da nação e do país, e menos ainda à bem-aventurança das futuras gerações. Poucas pessoas apenas - e mesmo assim raramente - podem reivindicar privilégio, prestígio ou honra pela importância e benefício comum gerados pelo trabalho que realizam. Raramente se espera que o trabalho "enobreça" os que o fazem, fazendo deles "seres humanos melhores", e raramente alguém é admirado e elogiado por isso. A pessoa é medida e avaliada por sua capacidade de entreter e alegrar, satisfazendo não tanto a vocação ética do produtor e criador quanto as necessidades e desejos estéticos do consumidor, que procura sensações e coleciona experiências ${ }^{3}$.

Não obstante, transpondo-se a noção de trabalho diante do contexto de modernidade líquida, apresentado pelo sociólogo ora mencionado, tem-se que:

A presente versão "liquefeita", "fluida", dispersa, espalhada e desregulada da modernidade pode não implicar o divórcio e ruptura final da comunicação, mas anuncia o advento do capitalismo leve e flutuante, marcado pelo desengajamento e enfraquecimento dos laços que prendem o capital ao trabalho. Pode-se dizer que esse movimento ecoa a passagem do casamento para o "viver junto", com todas as atitudes disso decorrentes e consequências estratégicas, incluindo a suposição da transitoriedade da coabitação e da possibilidade de que a associação seja rompida a qualquer momento e por qualquer razão, uma vez desaparecida a necessidade ou o desejo. Se manterem-se juntos era uma questão de acordo recíproco e de mútua dependência, o desengajamento é unilateral (...) A reprodução e o crescimento do capital, dos lucros e dos dividendos e a satisfação dos acionistas se tornaram independentes da duração de qualquer comprometimento local com o trabalho ${ }^{4}$.

\footnotetext{
${ }^{3}$ BAUMAN, Zygmunt. Modernidade Líquida. Rio de Janeiro: Zahar, 2001. p. 160-161.

${ }^{4}$ Idem. op. cit. p. 171.
} 
Em sua obra, Bauman relaciona a passagem da modernidade sólida à liquefeita ao período em que ocorreu o movimento dos trabalhadores.

No Brasil, fala-se em efetivas garantias atinentes ao trabalho a partir da edição da Consolidação das Leis do Trabalho - CLT (01/05/1943), cuja existência no ordenamento jurídico brasileiro é atribuída a Getúlio Vargas. Havia uma legislação esparsa anteriormente à CLT, mas esta é considerada o grande marco dos direitos trabalhistas por meio de uma normatização resultante de efetiva atuação do Estado em face das questões laborais. O referido diploma legal passou por várias transformações, acompanhado de outras legislações esparsas que também cuidam de regulamentar as relações de trabalho, conferindo direitos aos trabalhadores conforme a natureza dos contratos.

Contraditórios, porém, são o aumento de garantias normatizadas e o crescimento exponencial da inobservância dos direitos conferidos aos trabalhadores, desrespeito este que em parte resulta nas ações ajuizadas perante o Poder Judiciário, mas que muitas vezes nem sequer chega ao conhecimento da Justiça do Trabalho.

Logo, o desenvolvimento da pesquisa dar-se-á, num primeiro passo, ao estudo dos aspectos fundamentais dos Direitos Humanos, passando ao estudo dos direitos sociais em conformidade com a previsão contida na carta constitucional. Posteriormente, será verificado o espaço ocupado pelo Direito do Trabalho enquanto espécie dos direitos sociais, seguindo a modernidade líquida proposta por Zygmunt Bauman e, por fim, a atuação institucional do Poder Judiciário em face da realidade ora existente, por meio de posicionamentos jurisprudenciais e das políticas voltadas à conciliação.

Ademais, o estudo está voltado não apenas à análise do Direito do Trabalho em consonância com a teoria sociológica escolhida como referencial teórico, mas também àquela relação havida sob a perspectiva dos Direitos Humanos, atentando-se, inclusive, para a visão que o pensamento sociológico em questão confere a esta última seara de direitos.

Entretanto, observa-se de antemão que não é adequado pensar os Direitos Humanos enquanto produto de mera concessão legislativa casual. Sabe-se que a trajetória de consagração das conquistas relacionadas à dignidade humana representou em diversos momentos, para a humanidade, um quadro de intensa luta e resistência à opressão, à desigualdade e a diversas outras formas de exclusão de grupos que não atendem aos 
interesses daqueles que se encontram confortavelmente posicionados na esfera das relações de poder.

Os embates motivados na busca da valorização da condição humana, pelo simples fato de se existir, transcendem o olhar restrito, limitado e até mesmo ocidental na solução dos conflitos atinentes aos Direitos Humanos. Um dos grandes desafios atualmente é materializar o caráter universal a eles inerente, buscando mecanismos que assegurem a igualdade de maneira totalizante, num processo de eliminação das diversas formas de exclusão existentes.

É preciso (re)construir instrumentos para que o Direito do Trabalho se torne efetivo, deixe de ser vilão e passe a cumprir o seu papel de aliado dos trabalhadores na construção da tão almejada justiça social.

Afinal, não se pode construir um percurso voltado à afirmação dos Direitos Humanos com base na renúncia, no retrocesso, na concessão unilateral de garantias mínimas decorrentes de um longo processo histórico.

É preciso superar a ideologia de que aquele que ocupa a base das relações laborais, quando encontra um posto, está diante de um privilégio. Se o trabalho é um privilégio, ele tem representado nos últimos dias a consagração da garantia de desrespeito, pelo empregador, às condições regulamentadas pelo ordenamento jurídico. Um verdadeiro simulacro, uma vez que o verdadeiro privilégio caminha lado a lado com aquele que oferece os postos que, sob condições inferiores às garantidas, constituem objeto de verdadeira disputa pela grande massa vítima da exclusão social. Disputa pela própria anulação, para participar do retrocesso.

Assim, a presente pesquisa traz à tona as dificuldades ocasionadas pela modernidade líquida, transpondo o olhar particular de Zygmunt Bauman para o âmbito das relações laborais e as questões vivenciadas pelos trabalhadores sujeitos à proteção conferida pelo Estado, bem como às políticas a eles voltadas diante da intensa precarização do trabalho.

Questionam-se, portanto, as possíveis soluções aplicadas em face das consequências advindas do atual contexto, uma vez enfraquecidas as atuações sindical e estatal, colocando em xeque a consciência de classe e destacando a vantajosa possibilidade de se desrespeitarem garantias mínimas, de maneira que o presente trabalho se destina à 
realização de uma leitura do campo hipotético-normativo em contraposição à realidade hoje vivenciada pelos trabalhadores, processo este que conta com a atuação do Estado, por meio de seus órgãos constituídos especificamente para a tutela do Direito do Trabalho. 


\section{DIREITOS HUMANOS}

O valor da pessoa humana enquanto conquista histórico-axiológica encontra a sua expressão jurídica nos direitos fundamentais do homem. É por essa razão que a análise da ruptura - o hiato entre o passado e o futuro, produzido pelo esfacelamento dos padrões da tradição ocidental passa por uma análise da crise dos direitos humanos, que permitiu o 'estado totalitário de natureza'. Este 'estado de natureza' não é um fenômeno externo, mas interno à nossa civilização, geradora de selvageria, que tornou homens sem lugar no mundo. ${ }^{5}$

A locução "Direitos Humanos" substituiu a expressão the rights of the man (os direitos do homem), corrigindo uma falha não apenas literal, mas que subsistiu ideologicamente por longo tempo na sociedade patriarcal, especialmente as antigas civilizações. Assim, a nova expressão surgiu para incluir toda a espécie humana no seu rol de exigências e enunciados.

Um dos primeiros problemas atinentes ao estudo dos Direitos Humanos reside na sua expressão ou denominação, uma vez que também são conhecidos como direitos naturais, direitos do homem, direitos fundamentais, liberdades públicas, direitos da personalidade, direitos da cidadania, direitos individuais, direitos subjetivos públicos, liberdades fundamentais, direitos fundamentais do homem e direitos humanos fundamentais.

Os Direitos Humanos representam uma expressão que também pode ser encontrada de outras formas, tais como "liberdades públicas" e "direitos fundamentais", tendo sido esta última, inclusive, a escolha constante da Constituição Federal de 1988.

A denominação aplicada guarda relação com a perspectiva históricocultural-sociológica que se utiliza para aplicar esta ou aquela expressão. Importa destacar que não se pretende imiscuir quanto ao particular em questão, pois o desenvolvimento do presente trabalho corresponde aos Direitos Humanos no âmbito das relações laborais ${ }^{6}$ e a influência exercida pelo contexto da modernidade líquida, sendo que a referida expressão é empregada aqui por mera conveniência de referencial, e nada obsta a utilização de

\footnotetext{
${ }^{5}$ LAFER, Celso. A reconstrução histórica dos direitos humanos: um diálogo com o pensamento de Hannah Arendt. São Paulo: Companhia das Letras, 1988. p. 118.

${ }^{6}$ Ademais, valendo-nos dos escólios da teoria kelseniana, poderíamos acresentar que o termo fundamental, sobre melhor expressar, quando agregado ao vocábulo direito, a função que hoje exercem os direitos do homem (e também os direitos humanos) na legitimação da ordem jurídico-política estabelecida, realça o status da norma que os agasalha, a norma fundamental. In QUEIROZ JÚNIOR, Hermano. Os direitos fundamentais dos trabalhadores na Constituição de 1988. São Paulo: LTr, 2006. p. 21.
} 
quaisquer das outras expressões utilizadas, visto que tal não prejudicará a compreensão da essência que a pesquisa busca atingir. Aliás, mais importante que as divergências terminológicas é reconhecer e afirmar pela eficácia de normas voltadas à dignidade humana e à consagração de valores essenciais que propiciem condições mínimas de sobrevivência num mundo onde a desigualdade e consequente exclusão aumentam a cada dia, originando reflexos que surpreendem e amedrontam a sociedade. E na seara do trabalho não é diferente!

Acerca do conceito de Direitos Humanos, afirma Bidart: "Son derechos básicos, sin los cuales no seria factibile una sociedad adecuada para el hombre que deben reconocerse a todo hombre por pertencer a (o derivan de) su modo de ser proprio",

Gorczevski, por sua vez, acentua:

Trata-se de uma forma abreviada e genérica de se referir a um conjunto de exigências e enunciados jurídicos que são superiores aos demais direitos, quer por entendermos que estão garantidos por normas jurídicas superiores, quer por entendermos que são direitos inerentes ao ser humano. Inerentes no sentido de que não são meras concessões da sociedade política, mas nascem com o homem, fazem parte da própria natureza humana e da dignidade que lhe é intrínseca; e são fundamentais, porque sem eles o homem não é capaz de existir, de se desenvolver e participar plenamente da vida; e são universais, porque exigíveis de qualquer autoridade política em qualquer lugar ${ }^{8}$.

$\mathrm{O}$ conceito de Direitos Humanos acima transcrito remete à sua fundamentação, sendo mister, para tanto, apurar a forma mais segura para garantir sua efetivação, impedindo que sejam violados. Logo, a fundamentação transcende o estudo da origem, prosseguindo à análise de seus objetivos, o que demanda a observância às posturas jusfilosóficas que constituem uma dicotomia formada pelos posicionamentos jusnaturalista e positivista.

Para exemplificar o jusnaturalismo, vale lembrar a tragédia grega Antígona, escrita por Sófocles, na qual a protagonista desrespeita a ordem dada por Creonte, rei de Tebas, no sentido de que não seria dado o direito ao sepultamento ao irmão dela, Polynices, morto em batalha, devendo ficar exposto aos abutres. Antígona rebelou-se

\footnotetext{
${ }^{7}$ BIDART, Adolfo Gelsi. Crisis e Afirmación de Derechos Humanos. Revista de la Facultad de Derecho de México. $\mathbf{N}^{\circ}$ 85, junio 1972. p. 153. Apud MAGALHAES, José Luiz Quadros de. Direitos Humanos. Sua história, sua garantia e a questão da indivisibilidade. São Paulo: Juarez de Oliveira, 2000. p. 4.

${ }^{8}$ GORCZEVSKI, Clovis. Direitos Humanos. Dos primórdios da humanidade ao Brasil de hoje. Porto Alegre: Imprensa Livre, 2005. p.17
} 
contra a determinação e enterrou seu irmão. Foi presa e levada até Creonte, que a questionou se conhecia a lei, ao que Antígona respondeu que sim. O rei treplicou, indagando o motivo da violação pela protagonista, que afirmou ter sido tal determinação um afronte à lei da justiça:

Tu o compreendeste. A tua lei não é a lei dos deuses; apenas o capricho ocasional de um homem. Não acredito que tua proclamação tenha tal força que possa substituir as leis não escritas dos costumes e os estatutos infalíveis dos deuses. Porque essas não são leis de hoje, nem de ontem, mas de todos os tempos: ninguém sabe quando apareceram. Não, eu não iria arriscar o castigo dos deuses para satisfazer o orgulho de um pobre rei. Eu sei que vou morrer, não vou? Mesmo sem teu decreto. E se morrer antes do tempo, aceito isso como uma vantagem. Quando se vive como eu, em meio a tantas adversidades, a morte prematura é um grande prêmio. Morrer mais cedo não é uma amargura, amargura seria deixar abandonado o corpo de um irmão. E se disseres que ajo como louca eu te respondo que só sou louca na razão de um louco?.

O direito natural nasce com o homem e não se separa de sua natureza, sendo anterior e superior, conforme afirmou Antígona, a qualquer norma posta pelo Estado, pois é universal e efetivamente atinge o ideal de justiça.

Com efeito, há de se frisar que não vem ao caso, para o desenvolvimento do presente estudo, analisar a evolução do posicionamento jusnaturalista, passando da tradição aristotélica ao chamado neojusnaturalismo, cabendo asseverar tãosomente que este pensamento atribui à existência do direito natural como antecessora do próprio Estado, ou seja, para os adeptos deste posicionamento os Direitos Humanos surgem antes mesmo da própria instituição estatal.

O positivismo, por sua vez, como o próprio vocábulo sugere, considera a norma posta, reconhecida pelo Estado, como aplicável, válida e legítima para a sociedade.

Assim, o direito ganha a característica da temporalidade, diferentemente da imutabilidade do direito natural, aliada à territorialidade, em contrapartida ao caráter universal insculpido na teoria jusnaturalista.

O último posicionamento mencionado fundamenta os Direitos Humanos, portanto, através da positivação, reconhecendo-os após a obediência às formalidades prescritas na lei, a fim de validar as normas produzidas pelo Estado, integrando um ordenamento jurídico posto e concretizado.

\footnotetext{
${ }^{9}$ SÓFOCLES. Antígona (Trad. Millôr Fernandes). São Paulo: Paz e Terra, 2003. p. 25-26.
} 
Neste mesmo diapasão, é válido apontar os princípios axiológicos dos Direitos Humanos, lastreados pelo artigo $1^{\circ}$ da Declaração Universal dos Direitos Humanos (1948) ${ }^{10}$, quais sejam, liberdade, igualdade e fraternidade (ou solidariedade). Como princípios, afirma-se que se encontram no nível hierárquico mais alto do ordenamento jurídico e, apesar da incompatibilidade de positivação de princípios sob a ótica do pensamento de Hans Kelsen, não se pode crer que, mesmo depois de toda a revolução axiológica pela qual o mundo passou, seja plausível afirmar a existência de um ordenamento jurídico totalmente desvinculado do âmbito valorativo.

\subsection{EVOLUÇÃO HISTÓRICA}

Não há como analisar a perspectiva dos Direitos Humanos, as garantias conquistadas e seus desafios sem considerar a sua história, sua evolução, especialmente porque subsidiam a compreensão do desenvolvimento do tema em questão, da realidade em que se encontra tal ciência.

Devem-se ao pensamento humanista as raízes filosóficas dos Direitos Humanos, eis que a ele estão intimamente ligadas. Considerar que o homem, pelo simples fato de ser humano e independentemente de qualquer característica acidental, merece ter sua dignidade observada, concede aos Direitos Humanos sua fundamentação filosófica.

A dignidade do homem encontra correspondência com diversas raízes filosóficas, tal como o estoicismo, corrente filosófica pós-socrática que afirma a universalidade em sua ética, a pré-existência da dignidade antes mesmo do nascimento do homem, a valorização da virtude. Cite-se, ainda, a ideologia impressa pelo cristianismo, apreciada quando se afirma a espécie humana como imagem e semelhança de Deus, o que lhe confere, por conseguinte, a igualdade e dignidade.

Note-se que a história dos Direitos Humanos não está relacionada apenas às primeiras normas positivadas e conhecidas nas antigas legislações, como o Código de Hamurabi, mas também a normas cuja natureza está vinculada à religião, já que pelas religiões é atribuído caráter sagrado à vida humana, sendo consectários os pensamentos que convergem à proteção do homem.

\footnotetext{
10 "Todos os homens nascem livres e iguais, em dignidade e direitos. São dotados de razão e consciência e devem agir em relação uns aos outros com espírito de fraternidade".
} 
Os gregos contribuem ao afirmar pela liberdade política, dignidade humana, moralidade, racionalidade, ressaltando-se que tais se encontram apenas na seara das ideias, uma vez que, na prática, via-se a tortura, o escravismo e a própria restrição ao exercício dos direitos políticos, o que parecia não atingir o direito natural. Lembre-se que a execução de dívida, por exemplo, poderia ser satisfeita mediante a tortura pelo litigante vencedor, que conquistava tal direito sobre aquele prejudicado pelo ato judicial definitivo.

Por sua vez, os romanos editaram a Lei das XII Tábuas, elaborada no século V a.C., que exerceu considerável influência na legislação encontrada no mundo ocidental, tendo sido identificados, por eles, traços comuns a todos os seres humanos, o que também consagra o conhecido princípio da igualdade, não obstante a existência de diferenças de ordem étnica, social, entre outras.

$\mathrm{O}$ cristianismo, com a sua pregação do amor ao homem, criado à imagem e semelhança de Deus, asseverou a igualdade dos homens, que são dotados de suprema importância no universo, afirmando a fraternidade e intrínseca dignidade humanas, o que contribuiu sobremaneira para o reconhecimento dos Direitos Humanos. Cite-se, por exemplo, São Tomás de Aquino, ícone da Escolástica ${ }^{11}$, segundo o qual o homem possui direitos naturais adquiridos por Deus, podendo reivindicá-los diante de eventuais arbitrariedades, pois a lei natural está relacionada à lei divina, impondo-se, portanto, a autoridade divina em detrimento das autoridades políticas exercidas por homens comuns.

Há que se ressalvar o período de perseguição e morte pelo qual a Igreja Católica fez a humanidade passar durante a Idade Média, especialmente a partir do século XIII, promovendo a inquisitio haereticae pravitatis - a inquisição, movimento que contribui ao estudo histórico dos Direitos Humanos, uma vez que demonstra um período de total supressão a toda e qualquer garantia, impondo medidas bárbaras e cruéis de forma arbitrária, ignorando o que se chama atualmente de direitos fundamentais, na medida em que se violaram os Direitos Humanos.

\footnotetext{
11 Também conhecida como escolasticismo, a escolástica (do latim scholastica) esteve presente na Idade Média, propondo a doutrinação com base em seus métodos nas escolas europeias daquele período. Com a responsabilidade de tutelar o arcabouço axiológico e espiritual contido no pensamento cristão, prezando pela unidade da Europa, a escolástica possui conteúdo filosófico, uma vez que seus pensadores se aprofundaram nos questionamentos da fé, que se consolidava, juntamente com os pressupostos teológicos e filosóficos. De todos os seus pensadores, destacam-se Agostinho de Hipona e Tomás de Aquino.

Um ponto discutido na escolástica é a busca do equilíbrio entre a razão e a fé, sendo que São Tomás de Aquino sofre influência da filosofia aristotélica. Aliás, os filósofos antigos exercem forte influência sobre a escolástica.
} 
Transpondo a ótica religiosa ao século XVI, marcado pela Reforma Protestante, encontra-se mais um passo importante aos Direitos Humanos, conforme se transcreve a seguir:

A Reforma Protestante, que rendeu ensejo à reivindicação e ao paulatino reconhecimento do direito à liberdade de opção religiosa e de culto, exatamente por propugnar, em favor do cidadão, pela efetivação do direito à escolha da religião ou do culto a ser professado, e a subsequente quebra da hegemonia da religião católica, é considerada um fator de subida importância na evolução do processo que conduziu ao nascimento dos direitos fundamentais. A esse respeito, escreveu Miranda, asseverando que a quebra da unidade da Cristandade, a Reforma e a Contrarreforma, a par de abrirem profundas fissuras individuais e políticas, perseguições e guerras político-religiosas, mostraram que a possibilidade de professar sem constrangimentos a sua própria fé e de praticar os respectivos atos de culto era algo de insubstituível ${ }^{12}$.

Retornando à história, em meados do século XIII, a Carta Magna, marco da experiência inglesa como declaração de direitos para o mundo, editada em 1215, restringiu o poder absoluto do monarca, estabelecendo, ainda, o princípio da previsão legal do crime, a liberdade de crença, a proporcionalidade na aplicação de penas, a liberdade de ir e vir, o direito à propriedade, entre outros.

Na Inglaterra, ainda, tem-se a Petition of Rights (1628), que estabeleceu o respeito à sentença legal e aos ditames da lei em caso de detenção ou aprisionamento de qualquer homem, ou mesmo em relação aos seus bens e garantias. O Habeas Corpus Act, regulamentado em 1679, assegurou o princípio da liberdade individual, passando tal instrumento, em 1816, a ser utilizado amplamente nas situações em que se restringia a liberdade de ir e vir.

Assinado aos 13 de fevereiro de 1689 e um dos ícones documentais concernentes à política moderna, o Bill of Rights estabeleceu parâmetros acerca das funções legislativas do parlamento em face da Coroa, delimitando os poderes da monarquia e conferindo garantias na esfera individual. Logo, o poder dos reis não seria doravante absoluto, pautando-se às limitações conferidas pelo parlamento e, sendo assim, o que marcou significativamente tal documento foi o fim do absolutismo, dando lugar ao poder popular, o que registra o surgimento dos fundamentos das modernas monarquias constitucionais.

${ }^{12}$ QUEIROZ JÚNIOR, Hermano. op. cit. p. 37-38. 
O grande marco posterior ao Bill of Rights deu-se aos 12 de janeiro de 1776, em Virgínia, na colônia inglesa situada no continente norte-americano. Denominada como "Declaração do Bom Povo da Virgínia", influenciada pelo pensamento iluminista, especialmente por Locke, Montesquieu, entre outros, a declaração asseverava que "todos os homens são por natureza igualmente livres e independentes e têm certos direitos inerentes, dos quais, quando entram em qualquer estado de sociedade, não podem por qualquer acordo privar ou despojar os pósteros; quer dizer, o gozo da vida e liberdade, com os meios de adquirir e possuir propriedade, e perseguir e obter felicidade e segurança". ${ }^{13}$

A Declaração da Virgínia teve tamanha importância a ponto de influenciar e constituir base para a Declaração da Independência, elaborada por Thomas Jefferson, Benjamin Franklin e John Adams. Tal declaração data de 04 de julho de 1776, ratificando os termos expostos na Declaração da Virgínia e igualmente influenciados pela teoria de John Locke acerca dos direitos naturais, bem assim quanto ao contrato social; assegurou a igualdade entre os homens, dotados de direitos de natureza inalienável, tais como a vida, a liberdade e a busca da felicidade, entre outros pontos importantes como o estabelecimento dos governos pelos homens, que consentem e lhes conferem legitimidade para que representem seus interesses.

Assim, o maior marco da Independência Norte-Americana foi a previsão de direitos inerentes a todo ser humano, independentemente das diferenças.

A Revolução Francesa, iniciada com a tomada da Bastilha aos 14 de julho de 1789, abrangendo um lapso de dez anos, constitui um acontecimento que marcou significativamente o continente europeu, modificando a condução política e estabelecendo os fundamentos axiológicos dos Direitos Humanos, quais sejam, liberdade, igualdade e fraternidade (ou solidariedade).

Embora haja quem caracterize a Revolução Francesa como um acontecimento destinado à satisfação dos anseios burgueses, o que não pode ser contestado em face da eminente participação da burguesia naquele momento, defendendo seus interesses, há de se frisar que as intensas lutas e violências que marcaram os dez anos de revolução, aliadas às transformações políticas influenciadas pelos enciclopedistas e filósofos que passaram por aquele momento, tais como Locke, Diderot, Kant, Voltaire, Montesquieu, entre outros, proporcionaram a Declaração Universal dos Direitos do Homem e do Cidadão, constituída de dezessete artigos, pregando o universalismo e a

\footnotetext{
${ }^{13}$ GORCZEVSKI, Clovis. op cit. p.45.
} 
generosidade, anunciando a todos os povos o advento de um novo tempo, um tempo em que aos homens são reconhecidos direitos imprescritíveis e naturais, dentre eles a liberdade, a propriedade, a segurança, a justiça, consagrando, ainda, a separação entre os poderes.

\subsection{GERAÇÕES OU DIMENSÕES DOS DIREITOS HUMANOS?}

O Direito Internacional dos Direitos Humanos estabeleceu três categorias distintas de tais direitos, pautando-se pela especificidade de suas características em virtude dos valores que ensejaram o surgimento daqueles e seus respectivos momentos históricos.

A primeira geração ${ }^{14}$ teria surgido com as revoluções burguesas dos séculos XVII e XVIII, influenciadas pelo pensamento iluminista, pelas teorias propagadoras do liberalismo como sustentáculo do modelo econômico a ser seguido e, além disso, promovendo o predomínio da liberdade individual com amparo na teoria do direito natural postulada por John Locke, advogando pelo máximo de liberdade possível para todos.

Desta forma, a primeira geração de Direitos Humanos tem suas garantias denominadas individuais, vocábulo que marca a indigitada fase.

Entretanto, a defesa do modelo econômico liberal e posteriores transformações políticas ocorridas em tal período trouxe, por conseguinte, a instalação e ampliação de modos de produção exploradores, eis que a Revolução Industrial propiciou a consagração de um período marcado pelo trabalho submetido a péssimas condições, baixos salários, longas jornadas e contratação de crianças em condições igualmente deploráveis.

\footnotetext{
14 A denominação gerações dos direitos humanos é atribuída a Karel Vasak, Diretor do Departamento Jurídico da UNESCO, quando ministrou, em 2 de julho de 1979, a aula inaugural da Décima Sessão do Instituto Internacional de Direitos Humanos de Estrasburgo, defendendo a ideia de "Direitos Humanos de terceira geração". Sua classificação compreende os Direitos Humanos de acordo com seis diferentes critérios: $\left(1^{\circ}\right)$ o da importância dos direitos; $\left(2^{\circ}\right)$ o da natureza intrínseca dos direitos; $\left(3^{\circ}\right)$ do sujeito (ou titular) dos direitos; $\left(4^{\circ}\right)$ o do caráter positivo ou negativo dos direitos; $\left(5^{\circ}\right)$ o da perspectiva histórica; $\left(6^{\circ}\right)$ o da pertinência às gerações presentes e às gerações futuras. In MARTINS, Sérgio Pinto. Direitos fundamentais trabalhistas. São Paulo: Atlas, 2008. p. 55-56.
} 
Tais circunstâncias demandaram o estabelecimento de garantias de cunho social, já que o excessivo liberalismo fora praticado de forma desenfreada, ignorando as péssimas condições a que se submetia grande parte da população europeia naquele período.

Necessária, portanto, a intervenção do Poder Público, a fim de institucionalizar direitos sociais, requerendo a implementação de políticas públicas para garantir seu efetivo exercício, o que conferiu à segunda geração de Direitos Humanos o reconhecimento e denominação de direitos sociais, que correspondem, de um lado, ao Direito do Trabalho; de outro, o direito à seguridade social - que envolve a previdência, a assistência social e a saúde -, à cultura e à educação.

Neste diapasão, esclarece Hermano Queiroz Júnior:

Irmanados ao princípio da igualdade, tomado este em sua acepção material, de igualdade na lei e não perante esta, segundo a clássica definição de Bonavides, os direitos fundamentais de segunda dimensão nascem e se consolidam como demandas dos indivíduos, notadamente daqueles pertencentes às classes menos favorecidas da população, a prestações sociais estatais, na área da assistência social, saúde, educação, trabalho (dentre os quais inserimos os direitos fundamentais dos trabalhadores a férias, descanso semanal remunerado, $13^{\circ}$ salário, etc.), bem assim na seara das designadas 'liberdades sociais', nas quais constam, como veremos, os direitos à sindicalização e ao reconhecimento do direito de greve. Assim, os direitos fundamentais de segunda geração correspondem, em linhas gerais, aos direitos econômicos, sociais e culturais, em relação aos quais o Estado assume uma clara função promocional e que, em um primeiro momento, exatamente por demandarem ações prestacionais do Estado, experimentaram baixo percentual de 'justiciabilidade', quando comparados aos de primeira geração ${ }^{15}$.

Note-se que, no âmbito jurídico, tal período ficou conhecido como Constitucionalismo Social, compreendendo que os Direitos Humanos possuem uma função social que deve ser observada pelo ordenamento jurídico e efetivada pelo Poder Público, citando-se, como diplomas que exemplificam normas dotadas de índole social, as Constituições francesa (1848), mexicana (1917) e alemã (1919).

A terceira geração consiste no advento de Direitos Humanos referentes a toda a humanidade, a fim de eliminar a separação estabelecida entre Estados desenvolvidos e subdesenvolvidos, elencando, por exemplo, os direitos ao meio ambiente sadio, à paz, à livre determinação dos povos, à educação, ao bem-estar social, entre outros.

\footnotetext{
${ }^{15}$ QUEIROZ JÚNIOR, Hermano. op cit. p.48.
} 
Fala-se, ainda, na quarta geração de Direitos Humanos, relativa aos direitos à democracia, à informação, ao pluralismo, incluindo-se, ademais, a polêmica institucionalização dos direitos bioéticos, objetos de acirradas discussões na atualidade, controvérsias envolvendo questões políticas, científicas e religiosas, que correspondem a grande desafio a ser enfrentado não somente pelos ordenamentos jurídicos isolados, mas também pelo Direito Internacional Público.

A classificação dos Direitos Humanos em gerações ou dimensões, todavia, é motivo de críticas, sendo que uma delas corresponde ao descompasso ocorrido entre os momentos históricos estipulados em face das garantias neles incluídas, bem assim as diferenças existentes entre o direito interno de cada país em face do Direito Internacional Público. Afirma-se, também, que falar em geração induz à ideia de que a segunda, por exemplo, anule a primeira (ou com um direito surgido, outro desaparece), o que na verdade não ocorre, especialmente pelo princípio da complementaridade dos direitos humanos, que, ademais, são indivisíveis, interdependentes e inter-relacionados ${ }^{16}$.

Não obstante devam ser consideradas as razões pelas quais haja discordância da disposição dos Direitos Humanos de forma geracional (ou dimensional, como alguns defendem), deve-se admitir a importância didática para a compreensão da classificação elaborada. Aliás, as ciências humanas, diferentemente das exatas, contêm um grande diferencial que reside no fato de ser impossível estabelecer um estudo dotado de exatidão e sem controvérsias, posto que o homem está em constante transformação, a cultura não é criada e modificada seguindo regras que possam ser identificadas por meio de fórmulas, resultando em análises frias como aquelas efetivadas em laboratórios ou até mesmo para verificar a velocidade da luz.

Assim, válida a classificação instituída pelos estudiosos dos Direitos Humanos pelo simples fato de contribuir para a compreensão da disciplina estudada, ressaltando-se, de outra parte, que não se ampara (tampouco se pretende) em exatidão dos momentos históricos delimitados em contraponto às garantias positivadas pelos diversos ordenamentos.

\footnotetext{
${ }^{16}$ O Professor Antônio Augusto Cançado Trindade questiona a divisão dos direitos humanos em gerações ou dimensões, conforme a proposta de Karel Vasak em conferência realizada em Estrasburgo, no ano de 1979. In SEMINÁRIO DIREITOS HUMANOS DAS MULHERES: A PROTEÇÃO INTERNACIONAL. 25 de maio de 2000. Câmara dos Deputados. Brasília. Disponível em: <http://www.dhnet.org.br/direitos/militantes/cancadotrindade/cancado_bob.htm>.Acesso em: 20 julho 2011.
} 


\subsection{CLASSIFICAÇÃO}

A análise da classificação, no estudo da ciência do direito, compreende encontrar mecanismos denominativos que possibilitem a distinção de determinado objeto estudado na ciência em questão, visto que esta engloba uma série de proposições, enunciados e imperativos que, aos olhos do jurista, devem ser dissecados para que deles se extraia a essência, permitindo que sejam destacados em relação aos demais ramos e/ou objetos estudados.

Assim, o primeiro passo à classificação é verificar a natureza jurídica (no caso, a dos Direitos Humanos), que é, em primeiro plano, de direito público.

Passa-se, outrossim, ao estudo da classificação em virtude das fontes e, no caso do ordenamento jurídico brasileiro, por conta da previsão constitucional que lhes guarda, os Direitos Humanos possuem natureza constitucional.

O fato de os Direitos Humanos guardarem previsão na Constituição, leis, tratados, assegura-lhes a característica de serem típicos, posto que os direitos fundamentais atípicos estão à mercê de positivação pelos diversos ordenamentos jurídicos.

É possível dividir tal gênero em espécies formais e materiais de direito, sendo que os direitos formais estão expressamente previstos no ordenamento jurídico, enquanto os demais, embora não encontrem previsão legislativa ou constitucional, são considerados direitos fundamentais em virtude de seu conteúdo, característica ou importância.

Na seara da eficácia, a ciência cuida de estabelecer dois tipos: vertical, que cuida da relação existente entre o Estado e os particulares; e horizontal, havida entre os particulares.

Reflete-se acerca da eficácia sobre a inserção do objeto ora estudado (as relações de trabalho), uma vez que é controvertida a classificação do Direito do Trabalho em integrante do direito público ou privado.

Embora seja incontestável o fato de que as relações trabalhistas cuidam de relações jurídicas havidas entre os particulares (o que daria ensejo à classificação, relativamente à eficácia, como horizontal), não se pode ignorar a importância do Estado naquelas. 
Afinal, ao celebrar um contrato de trabalho, os indivíduos nele envolvidos - aquele que oferece sua mão de obra em troca de salário e o destinatário da mão de obra que, por outro lado, oferece a devida constraprestação - estão submetidos às condições mínimas estabelecidas pelo ordenamento jurídico, ou seja, não poderão estabelecer quaisquer cláusulas contratuais, sob pena de ser possível, ao trabalhador (em regra, menos favorecido economicamente em face daquele que o contrata), valer-se do Estado (Poder Judiciário) para tentar ver suas garantias mínimas, asseguradas em lei, devidamente efetivadas.

Se, ainda assim, questionar-se a classificação de tais comandos normativos em espécies do direito privado, valendo-se da máxima "pacta sunt servanda", que exprime o fato de que o contrato faz lei entre as partes, tal argumento cai por terra por aplicação dos princípios informadores do direito do trabalho, especialmente o princípio da primazia da realidade, segundo o qual pouco importa o convencionado no termo contratual, eis que os fatos devidamente provados devem ser sobrepostos às cláusulas contratuais, ignorando-as para os fins de concessão dos direitos assegurados ao trabalhador. Outro princípio importante é o da proteção, que satisfaz o enfoque protetivo do empregado pela legislação trabalhista.

Verificar, portanto, a essência da relação trabalhista é como vislumbrar um triângulo cujos vértices são compostos pelos contratantes, encontrando como ápice o Estado, que regula as condições mínimas e se encontra inerte, à disposição das partes (em especial do empregado, diante da fragilidade econômica que, via de regra, possui) para dirimir qualquer violação dos preceitos contidos no ordenamento jurídico.

\subsection{CARACTERÍSTICAS}

Não obstante o estudo da classificação outrora realizado, passa-se a cuidar do estudo das características dos Direitos Humanos, ou seja, dos seus elementos constitutivos, aqueles que os tornam especiais, conferindo-lhes posição diferenciada no ordenamento jurídico pátrio. 
Pois bem, partindo-se das atribuições explicitadas por Carlos Weis ${ }^{17}$, quanto às características dos Direitos Humanos, reconhece-se que estes são:

Inatos ou congênitos, eis que acompanham o homem do seu nascimento à sua morte. $\mathrm{O}$ homem, ao nascer, se insere num emaranhado de comandos normativos conhecido como ordenamento jurídico. Tais ordenamentos compreendem determinadas garantias conhecidas como fundamentais ao homem, conferidas a ele simplesmente por sua condição de ser e, portanto, diz-se que referidos dispositivos são inatos;

Universais, tendo em vista a sua extensão a toda a espécie humana, independentemente de tempo e lugar. Neste espeque, afirma-se que os direitos fundamentais não estão vinculados à consagração pelos ordenamentos jurídicos, pois a peculiaridade que os reveste faz-se traduzir a assertiva de que se supera a ideia de sua vigência particularizada, haja vista tratar-se de enunciados de vigência universal, exercido contra todos os Estados;

Absolutos, sendo possível a exigência do respeito aos mesmos de qualquer indivíduo ou comunidade, diferentemente dos direitos conhecidos como relativos, tais como aqueles advindos das relações contratuais nas quais predomina o brocardo jurídico "pacta sunt servanda", asseverado alhures;

Inalienáveis, posto que são intrínsecos à essência humana, não sendo possível a renúncia, transmissão ou transferência de tais direitos;

Invioláveis, ou seja, são inatacáveis, sob qualquer rubrica, legítima ou não, devendo ser consideradas, por óbvio, eventuais limitações impostas com o fito de se atingir o bem comum da sociedade, o que poderá ocorrer em situações excepcionais, citando-se, p. ex., a declaração de estado de sítio que poderá limitar o direito de ir e vir, disciplinada no art. 139, I, da Constituição Federal;

Imprescritíveis, haja vista que não caducam com o decurso do tempo. Quanto à imprescritibilidade, note-se que, embora a doutrina utilize tal expressão, o ordenamento jurídico brasileiro reconhece a prescrição como a perda do direito de ação e não do próprio direito, o que é denominado decadência. Entretanto, a imprescritibilidade assinalada se refere tanto à prescrição quanto à decadência para aqueles que consideram os termos jurídicos com excessivo rigor e formalismo.

Destaque-se, ainda, a diferença entre Direitos Humanos e cidadania, expressões que por muitos são equivocadamente utilizadas como sinônimas.

${ }^{17}$ WEIS, Carlos. Os direitos humanos contemporâneos. São Paulo: Malheiros, 1999. p. 109. 
A cidadania, diferentemente do conceito e das características expostos alhures, consiste em garantias concedidas (ou conquistadas), nacionais (ou seja, territoriais, podendo ser exigidas somente no Estado de sua nacionalidade), adquiridas ao longo da vida (e não inatas, como os direitos humanos), passíveis de renúncia ou perda e, por fim, mas não menos importante, relativas, em contraposição ao caráter absoluto daqueles direitos.

\subsection{PRINCÍPIOS}

Ainda dentro do estudo dos Direitos Humanos, faz-se necessário abordar alguns princípios básicos relacionados diretamente com o Direito do Trabalho.

Inicialmente, parte-se do princípio da igualdade, elemento básico que orienta a seara trabalhista.

O Direito do Trabalho surgiu por força do reconhecimento ao Princípio da Igualdade, tendo em vista que as relações trabalhistas são notadamente permeadas pela desigualdade, situação esta verificada não somente entre os trabalhadores e os detentores dos meios de produção, mas também entre os próprios trabalhadores.

Igualdade de trabalho, de salário, de condições, de tratamento. Tal princípio está associado à ideia de isonomia, à máxima aristotélica de equidade, segundo a qual se deve tratar igualmente os iguais e desigualmente os desiguais, considerando-se a medida de suas desigualdades.

Partindo-se de tal premissa, verifica-se a existência de legislações específicas editadas em favor de classes diferenciadas, a par das legislações gerais, pronunciadas a todos.

Todavia, deve-se ter cautela ao analisar as especificidades, pois observar-se-á o espírito da norma constitucional informadora do direito do trabalho e seus reflexos na ordem infraconstitucional. 
A título de exemplo, é possível considerar o artigo 62 da Consolidação

das Leis do Trabalho:

Não são abrangidos pelo regime previsto neste Capítulo:

I - os empregados que exercem atividade externa incompatível com a fixação de horário, devendo tal condição ser anotada na Carteira de Trabalho e Previdência Social e no registro dos empregados;

II - os gerentes, assim considerados os exercentes de cargos em gestão, aos quais se equiparam, para o efeito do disposto neste artigo, os diretores e chefes de departamento ou filial.

Parágrafo único. O regime previsto neste capítulo será aplicável aos empregados mencionados no inciso II deste artigo, quando o salário do cargo de confiança, compreendendo a gratificação de função, se houver, for inferior ao valor do respectivo salário efetivo acrescido de $40 \%$ (quarenta por cento).

Tal artigo confere aos referidos trabalhadores tratamento diferenciado ao relação ao que dispõe o artigo $7^{\circ}$, XIII e XVI, da Constituição Federal ${ }^{18}$.

Porém, há de se questionar a constitucionalidade de tal artigo do diploma consolidado, visto que a norma constitucional não excepciona nenhum caso à garantia de horas extras pelo trabalho em sobrejornada.

O princípio da razoabilidade, por sua vez, informa que a aplicação dos direitos fundamentais deve guardar condições razoáveis. Neste sentido, leciona Arion Sayon Romita:

Proíbe-se a distinção que não assente num fundamento razoável. A distinção é lícita, desde que razoável, não arbitrária. A distinção é aceitável, é plenamente justificável quando não discriminatória, podendo mesmo ser fator de igualdade.

Para estabelecer as distinções justificáveis, cabe atentar para as diferenças e semelhanças essenciais existentes na sociedade. Dois critérios são assentados pela doutrina: o primeiro manda atender "à existência de um fundamento razoável; o segundo critério é o que decorre da existência do arbítrio, como preleciona Guilherme Machado Dray".

O que ressalta neste nova visão do princípio de igualdade é a vedação geral do arbítrio, isto é, a proibição de medidas legislativas arbitrárias. Entende-se por arbitrária a lei que trate desigualmente situações objetivamente iguais ou igualmente situações objetivamente desiguais, sem que haja uma razão que justifique a diferença ou a identidade de tratamento. Deve haver uma igualdade proporcional ${ }^{19}$.

\footnotetext{
${ }^{18}$ Artigo $7^{\circ}$. São direitos dos trabalhadores urbanos e rurais, além de outros que visem à melhoria de sua condição social (...) XIII - duração do trabalho normal não superior a oito horas diárias e quarenta e quatro semanais, facultada a compensação de horários e a redução da jornada, mediante acordo ou convenção coletiva. (...) XVI - remuneração do serviço extraordinário superior, no mínimo, em cinquenta por cento à do normal.

${ }^{19}$ ROMITA, Arion Sayão. Direitos fundamentais nas relações de trabalho. 3.ed. São Paulo: LTr, 2009. p. 205.
} 
Embora o fundamento da posição acima transcrita seja válido, à medida que se considera a razoabilidade relacionada única e exclusivamente à proibição do arbítrio, sobretudo no campo normativo, reduz o seu conteúdo, eis que dá margem à sua utilização em desfavor do trabalhador. Afinal, nem tudo que não é arbitrário pode ser afirmado como razoável.

Importante, sim, aplicar a razoabilidade no exercício da equidade, atentando-se ao acima exposto.

Por fim, o princípio da equalização social, compreendido "no sentido de fomentar a promoção das pessoas socialmente desfavorecidas em confronto com outras pessoas de condição social mais favorável" ${ }^{, 20}$, talvez seja o mais importante na seara trabalhista.

Sua importância nasce a partir da ideia de concepção do fundamento axiológico da solidariedade, valor que dá base ao surgimento dos direitos sociais, no sentido de se promover a compensação das vantagens e desvantagens havidas no seio social entre as classes econômicas, a fim de buscar um equilíbrio razoável nas relações entre os particulares, com atuação, para tanto, do próprio ente estatal.

Verifica-se, pois, a necessidade de que os princípios ora mencionados sejam utilizados de forma complementar, pois a utilização isolada poderá implicar a manutenção da desigualdade e exploração. Tais princípios não informam apenas a edição de leis, mas também a análise das situações concretas levadas ao conhecimento jurisdicional, que obviamente não se restringirá a eles, mas poderá utilizá-lo como ponto de partida, sempre à luz do diploma constitucional e dos princípios informadores do Direito do Trabalho em si.

${ }^{20}$ Idem. op. cit. p. 208. 


\section{DIREITOS SOCIAIS}

O estudo dos direitos sociais demanda atenta reflexão acerca dos contrastes sociais existentes, sobretudo quando se parte do Brasil como paradigma.

A Constituição Federal elenca, por meio do artigo $6^{\circ}$, os direitos sociais consagrados pela República:

São direitos sociais a educação, a saúde, a alimentação, o trabalho, a moradia, o lazer, a segurança, a previdência social, a proteção à maternidade e à infância, a assistência aos desamparados, na forma desta Constituição ${ }^{21}$.

A leitura do dispositivo constitucional acima possibilita uma série de questionamentos que dialogam, inclusive, com outros campos do saber, como a sociologia, a economia, a filosofia, entre outros.

É inconteste o fato de que os direitos sociais decorrem de um constante processo de luta na tentativa de se ver materializada a compensação de bens e vantagens, afirmada pelo Professor Fábio Comparato, ferramenta imprescindível a minimizar o alto índice de exclusão social e consagrar, na prática, a indistinta valorização da dignidade da pessoa humana como um dos pilares fundamentais do Brasil (artigo $1^{\circ}$, III, da Constituição Federal).

Não se pode ignorar o processo histórico que desencadeou a consagração dos direitos sociais, uma vez que o Brasil possui inúmeros problemas relacionados ao gênero em questão, dentre os quais podem ser citados o grave problema fundiário e a exploração de mão de obra escrava até hoje - prova disso é a enorme quantidade de lamentáveis focos descobertos por meio da atuação do Ministério Público do Trabalho e do Ministério do Trabalho e do Emprego.

Com efeito, é necessário observar a recente Proclamação da República, ocorrida há pouco mais de um século, mas ainda carente de ver o fim do domínio oligárquico no Estado, uma vez que a política constitui um entrave à efetivação dos direitos sociais diante de um ente estatal que valoriza a democracia formalmente; porém,

\footnotetext{
${ }^{21}$ BRASIL. Constituição Federal, 1988.
} 
na prática, se esquiva de olhar para a dignidade de cada cidadão independentemente de qualquer condição.

Grave é o processo estrutural que alicerça o contexto de desigualdade, desaguando na alienação e ausência de consciência social daqueles que dela precisam para promover uma transformação dos setores políticos e sociais da nação. Falta educação, moradia, trabalho e, acima de tudo, boa parte da população brasileira cruzou o espaço da invisibilidade da dignidade humana, sendo que a inércia constitui um dos fatores responsáveis pela manutenção da realidade social desgastada e empobrecida.

A tentativa de se traçar um esboço histórico desencadeador do surgimento dos direitos sociais guarda intrínseca relação com o exercício de um direito fundamental, qual seja, a liberdade.

Durante muito tempo na história do homem, a formação da sociedade conduziu à exploração manifestada pelo cerceamento do direito de ser livre, por longo período não consagrado como tal, pois sua conquista enquanto verdadeiro direito requereu um processo de luta e afirmação.

Com o fim da Idade Média e o marco histórico da Revolução Francesa, travou-se uma luta em busca da liberdade, da garantia ao homem no sentido de desenvolver suas capacidades nas mais diversas acepções, gozando de um estado de verdadeira autonomia.

Passou-se, desta forma, a uma nova concepção do ente estatal dentro do estudo da Teoria do Estado, traçando a perspectiva de que o tal ente surgiu para e em favor do homem, diversamente do conceito de outrora, pelo qual o ser humano estava subordinado e à mercê do soberano.

As lutas travadas culminaram, como se sabe, com a ascensão da burguesia ao poder (político, frise-se). Aos poucos, tal classe conquistou o poder em todas as esferas possíveis da vida em sociedade, uma vez que o poder político em mãos possibilitou a retenção do monopólio da forma a ser conduzida a vida de todos os cidadãos submetidos a tais ideais. 
Assim, o arcabouço ideológico de outrora foi substituído pelos ideais burgueses, de maneira que o espaço social passou por uma enorme transformação, norteada pelo lema em busca de igualdade, liberdade e fraternidade.

Difícil detectar exatamente o erro do processo revolucionário, mas a exclusão social não apenas continuou, como se intensificou sob vários aspectos. A revolução não foi totalizante, foi para uma parcela, e talvez este tenha sido o grande erro a não universalização.

A marginalização da classe operária a par dos meios de produção propiciou o questionamento quanto à garantia indistinta do lema revolucionário francês, trazendo novas formas de reivindicações.

De fato, a liberdade conquistada não o fora de maneira genérica. Ao contrário, representou verdadeiro simulacro da classe em ascensão, a fim de que esta conquistasse o tão almejado poder, de sorte que o ser livre passou a usufruir dessa faculdade explorando outros seres humanos potencialmente livres.

Agravou-se, então, a marginalização dos operários que haviam se dirigido com suas famílias para os grandes centros urbanos e, diante de tal situação, estes se viram numa relação de total dependência de fornecer mão de obra de toda a família (inclusive crianças) em troca da mera sobrevivência.

Jornadas de trabalho extenuantes em ambientes insalubres e perigosos, sem qualquer contraprestação digna de garantir condições mínimas de sobrevivência, a verdadeira penosidade vivenciada pela classe desfavorecida deu espaço ao surgimento de uma série de reivindicações.

Nesse contexto surge uma nova luta, agora pela garantia dos direitos sociais numa perspectiva de compensar as inúmeras desigualdades encontradas no seio social. Afinal, a burguesia ignorara um dos fundamentos de seu lema, ou seja, a fraternidade.

A luta consistia, pois, em exigir do Poder Público a garantia de direitos mínimos compensatórios, voltados à manutenção de condições dignas de sobrevivência, especialmente dos excluídos do processo de apoderamento dos meios de produção. 
Os direitos sociais, portanto, podem ser entendidos como aqueles que, norteados pelo princípio da dignidade da pessoa humana, representam a concatenação dos esforços envidados pelo Estado, por força de uma luta social antecessora, de uma lógica compensatória num contexto naturalmente desigual, com o fim de estabelecer, indistintamente, condições mínimas e dignas de sobrevivência.

É possível recorrer, também, à definição atribuída por Cesarino Júnior em relação aos direitos sociais, segundo o qual:

Direito Social é a ciência dos princípios e leis geralmente imperativas, cujo objetivo imediato é, tendo em vista o bem comum, auxiliar as pessoas físicas, dependentes do produto de seu trabalho para a subsistência própria e de suas famílias, a satisfazerem convenientemente suas necessidades vitais e a ter acesso à propriedade privada ${ }^{22}$.

A concepção ora transcrita coloca os direitos sociais em forte diálogo com o trabalho. Por tal razão, não se pode analisar o Direito do Trabalho sem conferir um olhar ao trabalho em si e, ainda, a todos os direitos sociais informados pela Constituição Federal.

\subsection{DIREITOS SOCIAIS EM ESPÉCIE}

Partindo, pois, dessa lógica de concepção dos direitos sociais e sua aplicação no ordenamento jurídico brasileiro, como dito alhures, o principal dispositivo constitucional que cuida de tais direitos é o artigo $6^{\circ}$. Logo, embora o objeto do presente estudo seja especificamente o Direito do Trabalho, é importante refletir, ainda que sem esgotar todas as discussões peculiares possíveis de serem estabelecidas, acerca dos demais direitos sociais previstos na Constituição Federal de 1988, para que se compreenda a essência norteadora do Direito do Trabalho.

${ }^{22}$ CESARINO JÚNIOR, Antonio Ferreira. Direito Social Brasileiro. 6.ed. São Paulo: Saraiva, 1970. p. 29. 
Deve ficar claro, portanto, que a importância de se visitar cada direito social, mesmo no contexto do presente estudo, reside em buscar os principais pontos de convergência que possuem, assim como verificar que os direitos sociais estão interligados e, por tal razão, há um diálogo estabelecido entre eles.

Cabe ressaltar, ademais, que o direito social do trabalho será analisado oportunamente, uma vez que representa o principal direito social objeto do presente estudo e, assim, terá destaque num capítulo específico.

\subsubsection{EDUCAÇÃO}

O primeiro direito social previsto no artigo $6^{\circ}$ é a educação.

Considerado um meio apto a superar os entraves ideológicos que acarretam a alienação dos indivíduos, a educação é um dos primeiros contatos do indivíduo no contexto das relações sociais, de maneira que possibilita o desenvolvimento da nação.

O cenário brasileiro apresenta um grave quadro no que diz respeito à educação. A começar pelo alto índice de analfabetismo, a dificuldade de se formar neste país representa um obstáculo difícil de ser rompido.

E quando há acesso à educação, o problema é a qualidade. O ensino básico carece de investimentos, encontra-se precarizado por força de diversos fatores, dentre eles a desvalorização do docente, o qual é marginalizado - embora protagonista - de todo o processo educacional, servindo como um mero instrumento de mão de obra sem incentivos de melhorar sua qualificação.

O professor brasileiro depara-se, desde o início, com um grave conflito: desempenhar satisfatoriamente seu mister, cumprindo sua missão de instigar a busca pelo conhecimento e desenvolvimento pessoal de seus alunos, diante de um sistema precário e sem maior atenção do Estado, que remunera aquele profissional sem lhe conferir qualquer valor ou prestígio, fazendo com que ele aumente sua jornada de trabalho, o que naturalmente reflete na qualidade dos serviços. 
O aluno se vê diante de um sistema educacional público falido, desatento às suas necessidades e preocupado apenas com números. Prova disso, a exemplo da supervalorização dos dados estatísticos, é o sistema de aprovação continuada praticado no Estado de São Paulo, que dificulta sobremaneira - para não falar "impossibilita" - a reprovação de um aluno, sob a justificativa de se evitar a evasão e, assim, muitos concluem o ensino médio mal sabendo ler e escrever. Além disso, o discente está limitado a um sistema carente de recursos que o incentivem a buscar o conhecimento e o crescimento enquanto ser humano consciente de seu papel na sociedade.

Assim, a falta de incentivo aos protagonistas do sistema educacional professor e aluno -, conjugada com vários outros fatores que repercutem negativamente no referido contexto, acarreta uma realidade lamentável, cuja reversibilidade está invariavelmente condicionada a um cuidado especial do Estado e esforço absoluto do administrador público, por meio de políticas públicas voltadas à valorização do processo fundamental ao desenvolvimento do país.

Os dados estatísticos trazem algumas comprovações no que diz respeito ao analfabetismo e à evasão escolar, conforme o Instituto Brasileiro de Geografia e Estatística $(\mathrm{IBGE})^{23}$.

Não obstante tenha havido a redução do índice de analfabetismo (33\% em 1970, razão esta reduzida para 11,8\% em 2002), a desigualdade regional é gritante: na área urbana da região Sudeste, tal índice corresponde a 6,2\%, razão não muito diferente da área urbana da região Sul $(5,8 \%)$, mas extremamente desproporcional à área rural da região Nordeste $(39,1 \%)$.

Também é assustadora a realidade brasileira quanto ao índice de evasão, sendo que em 2000 o importe de matrículas efetuadas no ensino fundamental correspondeu a pouco mais de trinta milhões, contando com 2.647 .000 concluintes. O índice de evasão, de 1994 a 2000, teve um crescimento à razão de 67\%, segundo dados do instituto acima mencionado.

O quadro do ensino superior segue o triste contexto da educação básica na esfera pública, a começar pelo difícil acesso, pois embora seja mais fácil ingressar numa

${ }^{23}$ INSTITUTO BRASILEIRO DE GEOGRAFIA E ESTATÍSTICA. Dados sobre a educação no Brasil. Disponível em: < http://www.ibge.gov.br/ibgeteen/datas/escola/dados.html>. Acesso em 20 julho 2011. 
universidade privada, o problema de ordem financeira muitas vezes impede a integralização do curso. Aliás, relativamente às mensalidades praticadas, a realidade do ensino superior privado no país permitiu um processo de verdadeira mercantilização, no qual os diplomas são "vendidos" sem grandes preocupações com seus "consumidores" ou "clientes".

O investimento em pesquisa é carente, especialmente nos campos do saber que não são alvos do interesse econômico.

E se já é difícil mencionar a educação com todos os seus problemas estruturais e sua insuficiência relativamente ao que é essencial, a dificuldade se potencializa exponencialmente quando se fala na educação em Direitos Humanos, fundamental como emancipadora de qualquer sociedade que vise respeitar seus indivíduos e valorizar a dignidade da pessoa humana.

A educação em Direitos Humanos é uma via importantíssima para se pensar numa sociedade preocupada com as instituições democráticas e as esferas de poder, partindo da efetiva consciência social de cada cidadão. Para isso, é imprescindível a formação de profissionais preocupados com a condição humana e os preceitos informadores dos Direitos Humanos, a fim de que se universalizem, da melhor forma possível, os instrumentos relacionados às exigências de garantias atreladas a tal contexto, assim como a prática no cotidiano dos ensinamentos que os direitos humanos possibilitam.

É importante, nesse sentido, repensar o sistema educacional brasileiro na construção de um projeto que coloque os campos do saber em diálogo constante para o desenvolvimento humano em sua plenitude, possibilitando a construção consciente do papel de cada cidadão, de maneira que a interdisciplinaridade seja uma constante e o papel do educador seja revisto e valorizado como merece, dada a enorme importância que desempenha na transformação social por meio da transmissão de valores essenciais à vida humana.

A mudança da educação deve estar voltada a fazer com que a realidade educacional brasileira deixe de conduzir os cidadãos a um estado de verdadeira alienação. Talvez seja esse o motivo que leva os governantes à postura de total esquiva no sentido de resolver efetivamente os graves problemas enfrentados na seara em questão, o que facilita 
a manutenção desse nível governamental no cenário político brasileiro e o questionamento na esfera do poder público seja o menor possível.

Não se vislumbra, portanto, a urgente, radical e necessária mudança do direito social à educação que não parta de um forte embate travado pelos movimentos sociais voltados à emancipação da sociedade por força de um sistema educacional decente e que valorize os atores sociais nele inseridos em todas as suas dimensões.

\subsubsection{SAÚDE}

O segundo direito social mencionado no artigo $6^{\circ}$ é a saúde.

Refletir sobre o direito à saúde enquanto direito social e, portanto, na perspectiva dos direitos humanos, implica imediatamente uma questão conceitual. Afinal, o conceito de saúde pode ser atribuído sob diversos pontos de vistas e delimitações filosóficas.

Saúde pode ser a não doença, a profilaxia, a busca pela cura, ou seja, tudo que se relaciona ao sistema oferecido pelo Estado por meio de serviços públicos que dialogam com os problemas de saúde dos cidadãos.

Porém, é possível atribuir uma concepção ainda mais ampla à saúde, que transcenda a visão reducionista de considerá-la apenas relacionada a hospitais ou concessão de medicamentos, no sentido de buscar as condições mínimas aptas a garantir uma boa qualidade de vida aos cidadãos. Assim, a saúde estaria relacionada a vários outros aspectos que não são imediatamente ligados a ela quando se pensa no seu conceito. O meio ambiente sadio, o tratamento de esgoto, a alimentação adequada e acessível, o incentivo aos esportes, a educação para uma vida saudável, o combate às diversas formas de vícios, entre tantos outros, possibilitam inferir que a questão da saúde não pode ser considerada sob o ponto de vista restritivo da não doença ou do tratamento de moléstias. 
Aliás, a concepção de saúde do Sistema Único de Saúde segue uma ótica mais ampliada:

Na verdade, o SUS representa a materialização de uma nova concepção acerca da saúde em nosso país. Antes a saúde era entendida como "o Estado de não doença", o que fazia com que toda a lógica girasse em torno da cura de agravos à saúde. Essa lógica, que significava apenas remediar os efeitos com menor ênfase nas causas, deu lugar a uma nova noção centrada na prevenção dos agravos e na promoção da saúde. Para tanto, a saúde passa a ser relacionada com a qualidade de vida da população, a qual é composta pelo conjunto de bens que englobam a alimentação, o trabalho, o nível de renda, a educação, o meio ambiente, o saneamento básico, a vigilância sanitária e farmacológica, a moradia, o lazer, etc. De acordo com essa nova concepção de saúde, compreende-se que "os níveis de saúde da população expressam a organização social e econômica do país". Ou seja, há o acertado reconhecimento de que os indicadores de saúde da população devem ser tomados para medir o nível de desenvolvimento do país e o de bem-estar social da população ${ }^{24}$.

Se partir do primeiro enfoque do direito à saúde já é lamentável, que dirá se considerado o conceito mais abrangente?

O Brasil dispõe de um Sistema Único de Saúde idealizado por excelência, mas assim visto de maneira esparsa ou pouco aplicada. A concepção afirmada pelo próprio órgão estatal responsável pela saúde pública infelizmente não condiz com a realidade oferecida aos cidadãos que dela dependem.

A saúde pública conta com hospitais que não suportam a demanda populacional a ser atendida, carente dos equipamentos necessários à realização de diagnósticos e tratamentos dos seus cidadãos. Tudo isso numa realidade cultural que desprestigia os profissionais da área, remunerando-os pouco e os levando a se sujeitarem a jornadas excessivas para suprir a baixa remuneração que lhes é conferida.

Consequentemente, os planos de saúde atuam numa fatia essencial de responsabilidade do Poder Público, comercializando o direito à saúde e avocando, para si, a responsabilidade de garantir a excelência de tais serviços, uma vez que o Estado não responde satisfatoriamente com as suas obrigações.

Por outro lado, não se podem ignorar algumas conquistas no que diz respeito ao tratamento de doenças, como a quebra de patentes e concessão de coquetéis a

${ }^{24}$ BRASIL. Ministério da Saúde. Secretaria Executiva. Sistema Único de Saúde (SUS): princípios e conquistas. Brasília: Ministério Saúde, 2000. p. 5. 
soropositivos, assim como aos medicamentos fornecidos aos cidadãos. O Estado tem implementado uma série de políticas públicas voltadas à questão da saúde, mas longe de ser suficiente.

Afinal, o fato de haver um crescimento vertiginoso, ao longo dos anos, da exploração dos serviços de saúde no país, representa um indiscutível indicativo de que as políticas promovidas estão diametralmente opostas no que diz respeito à problemática da insuficiência dos serviços públicos.

Não é admissível que um direito fundamental seja objeto de mercantilização, é preciso reagir diante dos passos que o contexto de modernidade líquida tem causado a ponto de aumentar significativamente a exclusão social que assola o país, retirando dos indivíduos a dignidade e naturalizando a noção de que se trata de obrigação exclusivamente deles o gozo de dispositivos teoricamente chamados de direitos, mas que na prática implicam o exercício de inúmeros deveres na ordem da vida civil em busca de condições mínimas de sobrevivência.

\subsubsection{ALIMENTAÇÃO}

O direito à alimentação não constou da Carta Constitucional originária, incorporando tal documento político apenas com o advento da Emenda Constitucional $\mathrm{n}^{\circ}$ 64 , de 2010.

Não obstante o fato - curioso, diga-se - de causar impressão de que o direito à alimentação apenas ganhou a importância enquanto direito social no ano de 2010 , como se fosse possível ignorar a fome que assola o país, especialmente nas regiões Norte e Nordeste, integrá-lo ao rol dos direitos sociais parece representar mais uma saída retórica do legislador brasileiro.

Os números da fome no Brasil são assustadores. O Instituto Brasileiro de Geografia e Estatística (IBGE) aponta, relativamente à Segurança Alimentar no Brasil, com base em pesquisa realizada no ano de 2004, que: 
Em $65,2 \%$ dos 51,8 milhões de domicílios particulares brasileiros havia segurança alimentar. Dentre os 18 milhões com insegurança alimentar, 3,4 milhões foram classificados em situação de insegurança alimentar grave e 1,6 milhão destes domicílios estavam no Nordeste. Dos 14 milhões de pessoas que viviam em domicílios com insegurança alimentar grave, perto de 6 milhões moravam naqueles com rendimento mensal domiciliar per capita que não ultrapassava $\mathrm{R} \$ 65$ por pessoa. Em todas as regiões, a prevalência de insegurança alimentar foi maior nos domicílios com pessoas de menos de 18 anos de idade ${ }^{25}$.

É lamentável pensar em 14 milhões de pessoas passando fome, quando considerar que uma pessoa em tal situação já não é admissível. Os dados apresentados acima demonstram também a desigualdade relativa à região Nordeste, assim como o fato de que a situação de insegurança alimentar atinge sobretudo as crianças, agravando ainda mais a situação.

Há que se observar, por outro lado, a implementação de alguns programas sociais voltados à questão da alimentação.

O Programa Fome Zero, de iniciativa do governo federal, foi estabelecido em 2003 com o objetivo de "assegurar o direito humano à alimentação adequada às pessoas com dificuldades de acesso aos alimentos",26.

Conforme se depreende do sítio eletrônico da Presidência da República, o programa em referência compreende uma atuação articulada dos ministérios no sentido de garantir eficácia ao programa instituído, baseando-se na transversalidade e intersetorialidade, envolvendo os seguintes órgãos: Ministério do Desenvolvimento Social e Combate à Fome, Ministério do Desenvolvimento Agrário, Ministério da Saúde, Ministério da Educação, Ministério da Agricultura, Pecuária e Abastecimento, Ministério do Trabalho e Emprego, Ministério da Ciência e Tecnologia, Ministério da Integração Nacional, Ministério do Meio Ambiente, Ministério da Justiça e da Secretaria Especial de Políticas de Promoção da Igualdade Racial e Ministério da Fazenda.

É indiscutível a atuação do Estado em face do problema da fome, quando se observa a redução dos ainda elevados índices de subnutrição, por meio da denominada política social.

\footnotetext{
${ }^{25}$ INSTITUTO BRASILEIRO DE GEOGRAFIA E ESTATÍ́STICA. IBGE traça perfil inédito sobre Segurança Alimentar no Brasil. Disponível em: < http://www.ibge.gov.br/home/presidencia/noticias/noticia_visualiza.php?id_noticia=600>. Acesso em 20 julho 2011.

${ }^{26}$ BRASIL. Presidência. Fome Zero. Disponível em: <www.fomezero.gov.br/o-que-e>. Acesso em 20 junho 2011.
} 
As disparidades sociais traduzem estranheza quando se vê um setor da sociedade condenado à implementação de tais políticas, sob o argumento de que não passa de assistencialismo e não resolve o problema.

De fato, a crítica é importante na condução de um olhar mais amplo a uma perspectiva inicialmente restrita, e é indubitável que o denominado assistencialismo, puro e simples, não resolve o problema da fome. Tal assertiva é óbvia, uma vez que a questão em destaque é setorizada, mas decorre de uma totalidade social antagônica e marcada por uma série de desigualdades.

Porém, enquanto não se estabelecer uma política efetivamente voltada à questão social no Brasil, com a finalidade de reduzir a enorme desigualdade consolidada no país, deve o Estado se valer não apenas de um, mas de todos os programas sociais possíveis de resolver o grave problema do acesso à alimentação.

\subsubsection{MORADIA}

O problema da falta de acesso ao direito à moradia no Brasil não é de hoje.

Um importante fator histórico, mencionado pelo Professor José Reinaldo de Lima Lopes, que certamente contribuíra para tal problema foi a escravidão, uma vez que não houve qualquer preocupação do Estado com os escravos libertos, de maneira que as cidades passaram a recebê-los, o que repercute na forma de ocupação das cidade, assim como no tocante à propriedade, uma vez que sua aquisição requer uma contraprestação impossível de ser satisfeita pelo escravo liberto (LOPES, p. 66-67).

O direito de moradia passou a integrar o rol dos direitos sociais a partir da Emenda Constitucional $\mathrm{n}^{\mathrm{o}}$ 26, de 2000, e, assim como ocorreu com o direito à alimentação, é curioso notar o reconhecimento tardio de tal espécie de direito enquanto direito social, especialmente se considerada a trajetória histórica do país.

Desde seu processo de colonização, o Brasil consagrou a dificuldade de acesso à moradia, a começar pelas capitanias hereditárias. 
As desigualdades brasileiras, no que diz respeito ao espaço territorial, podem ser identificadas tanto na cidade como no campo, sendo que ainda se aguarda a reforma agrária capaz de minimizar a má distribuição de terra que acompanha o país há tanto tempo.

Retornando, porém, ao direito de moradia, verifica-se uma intrínseca relação entre propriedade, cidade e moradia.

Com o surgimento da especulação sobre a propriedade, passa-se a vivenciar o acúmulo de terras por conta da facilidade de alienação, de forma a ajustar ou condicionar totalmente o direito de moradia aos interesses econômicos. Relativamente ao processo em questão, discorre o Professor José Reinaldo de Lima Lopes:

\begin{abstract}
A propriedade torna-se alienável e desaparecem os direitos tradicionais. Antes do advento do capitalismo, a terra, mesmo urbana, não era alienável facilmente, sobre ela eram constituídos direitos com prazo certo (de 99 anos ou mais) ou a título precário (as terras alodiais ou precárias do direito português). Isto significa que não havia interesse nem possibilidade de acumulação de terras de maneira especulativa (Marx, 1978). As posturas municipais, o controle da transferência da terra, dificultavam sua alienação e, portanto, a ideia de que a terra era um bem como qualquer outra mercadoria. Ganhar dinheiro pela terra era muito mais difícil. Certo que, com a monetarização crescente das economias, os direitos eram transformados em prestações em moeda. Mas as prestações não eram reajustáveis, eram fixas, e assim ninguém especulava sobre a terra propriamente ${ }^{27}$.
\end{abstract}

Com relação ao direito à cidade, a problemática reside em enxergá-la enquanto espaço privado, quando deveria receber o atributo de espaço público.

O espaço urbano é representado por um amontoado de seres humanos (moradores ou não) que, dentre várias formas de classificação no contexto social, identificam-se pelo local em que residem. A localização geográfica segrega e potencializa o processo de exclusão social, constituindo mais um fator a desencadear a discriminação.

\footnotetext{
${ }^{27}$ LOPES, José Reinaldo de Lima. Direitos Sociais: Teoria e Prática. São Paulo: Método, 2006. p. 69-70.
} 


\subsubsection{LAZER}

O direito ao lazer dialoga com o direito do trabalho, considerando a média da sociedade brasileira, que se ativa em jornadas de trabalho extensas e vê na atividade laboral o único meio socialmente aceito para sua sobrevivência.

O trabalho ocupa grande parte do tempo de vida das pessoas, delimitando e condicionando suas ações no contexto laboral, de sorte que o labor visa beneficiar os interesses daquele que emprega.

O lazer surge em decorrência do tempo fundamental para que o indivíduo possa manifestar sua dimensão humana distante da lógica das obrigações no contexto das relações de produção. Pouco se encontra em termos de estudos dedicados ao lazer, e sua concepção é objeto de divergência por muitos, sendo válido transcrever o seguinte conceito:

O lazer é um conjunto de ocupações às quais o indivíduo pode entregarse de livre vontade, seja para repousar, seja para divertir-se, recrear-se e entreter-se ou, ainda, para desenvolver sua informação ou formação desinteressada, sua participação social voluntária ou sua livre capacidade criadora após livrar-se ou desembaraçar-se das obrigações profissionais, familiares e sociais ${ }^{28}$.

Partindo-se da concepção acima, é possível afirmar que o lazer está ligado ao exercício da liberdade, representando uma forma de manifestação desta, “desinteressada", voltada à satisfação pessoal do homem e importante à sua vida.

Enquanto direito social, o lazer deveria ser observado pelo Estado, o qual tem o dever de promover ações voltadas à garantia de tal direito. Afinal, por meio do lazer é possível identificar a manifestação cultural de um povo e a formação de sua identidade.

Todavia, evidencia-se o aumento do espaço privado em detrimento do espaço público, e para constatar tal situação não é preciso muito esforço. A própria cidade

\footnotetext{
${ }^{28}$ DUMAZEDIER, Joffre. Lazer e Cultura Popular. São Paulo: Perspectiva, 1973. p. 34.
} 
não dispõe de espaços públicos suficientes ao exercício do lazer e este fica condicionado ao poder aquisitivo do cidadão que pretende usufruir de tal direito, o que acarreta a verificação de que o lazer não é oferecido, embora devesse, por força de um comando constitucional. Ele é, sim, vendido, tem preço e apenas mediante uma contraprestação é que poderá ser exercido.

Não se vê, outrossim, qualquer indício de que haverá alguma mudança social sobre o assunto em questão. Atualmente, o espaço de lazer mais comum da média da sociedade é representado pelo shopping center.

É importante destacar que o shopping center não é lazer, mas sim espaço de consumo. Porém, é comum aos membros da sociedade o exercício do lazer em tal espaço, nos termos do conceito acima transcrito.

Obviamente que não há apenas um tipo de shopping center destinado a uma parcela exclusiva da população. É possível encontrar vários complexos destinados a determinada classe, com lojas mais ou menos acessíveis e projetados para receber e agradar um público específico, com praças de alimentação, cinemas, teatros, bares, livrarias, lojas de vários tipos de produtos e para atender a todas as faixas etárias.

Assim, dá-se à população a falsa sensação de usufruir do direito ao lazer, alimentando a ideologia perversa que leva ao consumismo e mais, permitindo seu crescimento e o fortalecimento da relação de dependência dos indivíduos enquanto consumidores e submetidos à ideologia de que o poder de compra propicia a felicidade. 


\subsubsection{SEGURANÇA}

A segurança tornou-se uma tônica nos dias atuais, sobretudo nos grandes centros do Brasil, região com dados alarmantes relativamente às ocorrências policiais $^{29}$.

É possível encontrar discursos envolvendo tal questão de diversas formas, das quais destacar-se-ão basicamente duas: a ótica estatal e a prática no seio social, esta última havida entre os próprios indivíduos nas relações de interação ocorridas no cotidiano.

Na ótica estatal, visualiza-se uma preocupação atinente à segurança dos Estados, que se voltam à implementação de políticas públicas com o fim de garantir um território seguro aos seus cidadãos e evitar a atuação de inimigos que representam ameaça à paz da sociedade e à vida dos indivíduos que nela se inserem ${ }^{30}$.

A segurança na ótica do seio social, por sua vez, não está relacionada às questões que envolvem o Estado - ao menos não diretamente -, mas que se inserem na população no decorrer das práticas sociais diárias.

A título exemplificativo, cite-se o aumento de condomínios dotados de vários recursos utilizados para garantir a máxima segurança possível dos moradores. Tal prática representa um grande atrativo oferecido pelo setor imobiliário no Brasil, procurado sobretudo por cidadãos com poder aquisitivo condizente com o padrão que lhes é assegurado. E os exemplos seguem para as escolas e shoppings, que constituem, ao lado da residência, os locais mais frequentados pelos filhos inseridos em tal classe de consumidores.

\footnotetext{
29 "Na cidade de São Paulo, no período de 1983-2000, observa-se um aumento real de 53,54\% no total de registros de ocorrências, acima do crescimento da população, que foi de $18,24 \%$. Em 2000, registrou-se o maior pico de ocorrências policiais. Nesse ano, foram registrados 675.157 crimes, o que dá uma média de 1.849 registros diários de crimes, 77 a cada hora. Os crimes contra o patrimônio experimentaram maior crescimento real $(72,68 \%)$. Desagregando, podemos perceber que os crimes que envolvem algum grau de violência aumentaram fortemente. É o caso dos roubos $(118,85 \%)$ e do roubo de veículos $(176,84 \%)$. As prisões por porte ilegal de armas cresceram $87,06 \%$, no período. Os crimes contra a pessoa oscilaram negativamente 13,58\%, não obstante os homicídios terem experimentado um aumento de 120,56\%". In OBSERVATÓRIO DE SEGURANÇA PÚBLICA. Análise da Criminalidade em São Paulo. Disponível em: <http://www.observatoriodeseguranca.org/dados/dados/agregadas>. Acesso em: 20 julho 2011.

${ }^{30}$ Nesse contexto, surgem diversos embates políticos, como os inúmeros expedientes utilizados pelos Estados Unidos da América na verdadeira guerra instaurada contra o terrorismo.
} 
A significativa procura por segurança, pela proteção e máxima garantia de que, apesar dos inúmeros contrastes e da desigualdade que assola a estrutura social, nenhum mal acontecerá mediante o pagamento do preço exigido, confere àqueles que possuem as condições para tanto a sensação de alívio. Como se fosse possível, inclusive, ignorar as verdadeiras causas estruturais das quais decorrem os problemas que ameaçam uma vida segura, os indivíduos que se enquadram na fatia social em questão não precisam se importar com os reflexos dos fatos sociais existentes, permanecendo narcotizados e convictos de uma aparente solução de seus problemas.

Nas relações entre os indivíduos, os meios utilizados para (a tentativa de) manter a segurança priorizam a proteção de dois principais interesses, quais sejam, a vida e a propriedade.

No caminho de uma análise acerca da segurança, Zygmunt Bauman estuda a comunidade, estabelecendo como fio condutor a díade pendular constituída pelos elementos segurança e liberdade:

\begin{abstract}
A promoção da segurança sempre requer o sacrifício da liberdade, enquanto esta só pode ser ampliada à custa da segurança. Mas segurança sem liberdade equivale à escravidão (e, além disso, sem uma injeção de liberdade, acaba por ser afinal um tipo muito inseguro de segurança); e a liberdade sem segurança equivale a estar perdido e abandonado (e, no limite, sem uma injeção de segurança, acaba por ser uma liberdade muito pouco livre). Essa circunstância provoca nos filósofos uma dor de cabeça sem cura conhecida. Ela também torna a vida em comum um conflito sem fim, pois a segurança sacrificada em nome da liberdade tende a ser a segurança dos outros; e a liberdade sacrificada em nome da segurança tende a ser a liberdade dos outros ${ }^{31}$.
\end{abstract}

A relação estabelecida entre os valores segurança e liberdade é marcada por uma situação de constante tensão, uma vez que não é possível ser livre e ter segurança na medida em que se deseja.

Uma vez que a segurança requer mais uma parcela da (limitada) liberdade que os indivíduos possuem, a tensão emerge do fato de que não se deseja abrir mão do mínimo que seja de liberdade.

${ }^{31}$ BAUMAN, Zygmunt. Comunidade: a busca por segurança no mundo atual. Rio de Janeiro: Jorge Zahar, 2003. p. 24. 
$\mathrm{Na}$ agenda dos Direitos Humanos, encontramos a liberdade nos seguintes instrumentos: Magna Carta (art. 1), Bill of Rights, Declaração dos Direitos do Homem e do Cidadão (arts. $1^{\circ}, 4^{\circ}$ e 11 ), a Declaração Universal dos Direitos Humanos de 1948 (arts. I a III, XIII, XVIII a XX, XXVII a XXIX), entre outros

A segurança, por sua vez, está prevista na Magna Carta (art. 41), na Declaração de Independência e na Constituição dos Estados Unidos da América, na Declaração Universal dos Direitos Humanos de 1948 (art. III), podendo ser encontrada também em outros instrumentos.

Diante do conflito entre os interesses postos em questão, a solução mais razoável é a realização de juízo de ponderação para balanceá-los da melhor forma possível, possibilitando uma realidade mais segura e sem desprezar absolutamente a liberdade dos indivíduos. Tal assertiva é simples no âmbito da retórica, mas quando deslocada para a prática se torna deveras complexa, pois o gozo de tais direitos está condicionado às condições socioeconômicas de determinada sociedade ou dos indivíduos em si, o que resulta em uma multiplicidade de fatores coexistentes num determinado espaço, minando novamente uma possível ameaça a ambos. Com isso, a realidade torna-se cíclica e não há a efetiva solução dos conflitos.

De fato, conforme afirmado por Bauman, a plena segurança somente é possível nas verdadeiras comunidades. Afirma, porém:

Os contemporâneos em busca da comunidade estão condenados à Sina de Tântalo; seu objetivo tende a escapar-lhes, e é seu esforço sério e dedicado que faz com que lhes escape. A esperança de alívio e tranquilidade que torna a comunidade com que sonham tão atraente será impulsionada cada vez que acreditam, ou lhes é dito, que o lar comum que procuravam foi encontrado. Às agonias de Tântalo se juntam, tornando-as ainda mais sofridas, as de Sísifo. 'A comunidade realmente existente' será diferente da de seus sonhos - mais semelhante a seu contrário: aumentará seus temores e insegurança em vez de diluí-los ou deixá-los de lado. Exigirá vigilância vinte e quatro horas por dia e a afiação diária das espadas, para a luta, dia sim, dia não, para manter os estranhos fora dos muros e para caçar os vira-casacas em seu próprio meio. E, num toque final de ironia, é só por essa belicosidade, gritaria e brandir de espadas que o sentimento de estar em uma comunidade, de ser uma comunidade pode ser mantido e impedido de desaparecer. $\mathrm{O}$ aconchego do lar deve ser buscado, cotidianamente, na linha da frente ${ }^{32}$.

${ }^{32}$ Idem, Ibidem. p. 22. 
Assim, diante da análise concernente à relação entre liberdade e segurança, vê-se que, em nome desta última, a concepção atual de liberdade é cada vez mais revista e, assim, reduzida.

Neste ponto, as duas perspectivas sobre segurança aplicadas na análise convergem para potencializar a restrição do direito à liberdade dos indivíduos de determinada comunidade (ou em nome de uma possível comunidade, uma vez que esta, nos dizeres de Bauman, não é encontrada nos tempos de modernidade líquida).

Por assim dizer, segurança e liberdade seriam plenamente possíveis diante de uma verdadeira comunidade, que não existe e está cada vez mais distante, embora se tente construí-la, o que, por outro lado, não exime o Estado de suas obrigações consagradas constitucionalmente, dentre elas a segurança.

Seja nas relações entre os indivíduos e os Estados ou dos próprios indivíduos entre si, se é possível afirmar que os Direitos Humanos postos em discussão são eficazes, tal assertiva refere-se exclusivamente aos solventes, àqueles que possuem patrimônio suficiente para garantir uma existência digna nos termos dos instrumentos de direitos humanos redigidos ao longo da trajetória histórica, fortes sobretudo no âmbito da retórica, mas que carecem de efetividade universal dentro de um contexto estrutural discriminatório e absolutamente seletivo.

Não se pode esquecer, porém, que a segurança pública constitui verdadeiro direito social sob a responsabilidade do Estado, que deve promovê-la por meio da efetivação de políticas públicas.

\subsubsection{PREVIDÊNCIA SOCIAL}

Associada ao bem-estar e à justiça sociais, a previdência social está inserida no rol dos direitos sociais, integrando as disposições sobre a ordem social, como um dos meios utilizados pelo Estado dentro de sua atuação no gênero da seguridade social, a qual também compreende os direitos à saúde e à assistência social (artigo 194 da Constituição Federal). 
A Previdência Social compreende o oferecimento, pelo Estado, de maneira genérica, indistinta, com caráter contributivo e de filiação obrigatória (conforme preconiza o artigo 201 da Constituição Federal), da proteção ao cidadão e a seus familiares dentro de situações específicas, como doença, morte, idade avançada, maternidade, desemprego, cumprimento de pena restritiva de liberdade (no qual se insere o auxílio reclusão), salário-família aos dependentes dos segurados que estiverem nos parâmetros legais de baixa renda, assim como pensão por morte.

O sistema de Previdência Social do Brasil tem encontrado algumas dificuldades de se manter em virtude dos problemas de arrecadação em contraste com os benefícios concedidos. Vê-se que a Previdência reluta em conceder benefício a muitos cidadãos, o que acarreta uma série de ações perante o Poder Judiciário em face da autarquia previdenciária.

A universalidade de cobertura, consagrada pelo diploma constitucional, é colocada em xeque na insuficiência do sistema da Previdência Social, que não consegue cumprir satisfatoriamente a proteção social aos cidadãos e respectivos familiares deles dependentes.

Tal situação dá margem ao surgimento de sistemas privados voltados a suprir a ausência de atuação estatal. O regime de previdência privada é um exemplo de meio descoberto pelas instituições financeiras no contexto do benefício da aposentadoria.

$\mathrm{Na}$ ótica dos direitos sociais, a previdência pode ser utilizada como exemplo, mais uma vez, da leniência do Estado em prestar os serviços públicos essenciais aos cidadãos, dando margem ao surgimento da exploração de tais serviços por instituições desvinculadas da seara estatal.

\subsubsection{PROTEÇÃO À MATERNIDADE E À INFÂNCIA}

É mister do Estado conferir uma atenção especial à maternidade e à infância, fases que demandam uma série de cuidados para o desenvolvimento de uma vida saudável. 
Logo, analisar a proteção à maternidade e à infância sob a ótica da Constituição Federal no gênero dos direitos sociais requer a constatação das políticas públicas implementadas com o intuito de proteger as gerações futuras.

Relativamente à proteção à maternidade, recentemente a sociedade conquistou a ampliação da respectiva licença, de quatro para seis meses, por força da aprovação da Lei $n^{\circ} 11.770 / 2008^{33}$, o que passou a ser considerado em consonância com o artigo $7^{\circ}$, XVIII, da Constituição Federal $^{34}$, por beneficiar a empregada e estar absolutamente em conformidade com os princípios consagrados pela carta constitucional, especialmente no que diz respeito aos direitos sociais.

Partindo-se do comando constitucional de proteção à maternidade, podem ser encontradas algumas medidas no plano infraconstitucional, como é o caso da Consolidação das Leis do Trabalho (CLT), que em seu Capítulo III dispõe sobre a proteção do trabalho da mulher (artigos 372 e seguintes), partindo, na Seção V, especificamente à proteção à maternidade (artigos 391 e seguintes).

$\mathrm{O}$ direito à amamentação representa uma das garantias estabelecidas pelo diploma celetista, que mediante o artigo 396 concede à mulher dois descansos destinados a tal mister ${ }^{35}$.

Outra garantia conferida pelo ordenamento jurídico à mulher, de forma a proteger a maternidade, é a estabilidade provisória prevista no artigo 10, II, "b", do Ato das Disposições Constitucionais Transitórias ${ }^{36}$. Assim, a gestante possui o direito ao trabalho, protegido contra a dispensa arbitrária ou sem justa causa, pelo período que abrange desde a confirmação da gravidez até cinco meses após o parto.

${ }^{33}$ BRASIL. Lei no 11.770 , de 9 de setembro de 2008. Cria o programa Empresa Cidadã, destinado à prorrogração da licença-maternidade mediante concessão de incentivo fiscal, e altera a Lei $\mathrm{n}^{\circ} 8212$, de 24 de julho de 1991. Diário Oficial da União. Brasília, DF, 10 set. 2008. p. 1.

${ }^{34}$ Artigo $7^{\circ}$ - São direitos dos trabalhadores urbanos e rurais, além de outros que visem à melhoria de sua condição social: (...) XVIII - licença à gestante, sem prejuízo do emprego e do salário, com a duração de cento e vinte dias. In BRASIL. Constituição Federal de 1988.

${ }^{35}$ Artigo 396 - Para amamentar o próprio filho, até que este complete 6 (seis) meses de idade, a mulher terá direito, durante a jornada de trabalho, a 2 (dois) descansos especiais, de meia hora cada um. In BRASIL. Decreto-lei ${ }^{\circ} 5452$, de $1^{\circ}$ de maio de 1943.

${ }^{36}$ Artigo 10 - Até que seja promulgada a lei complementar a que se refere o art. $7^{\circ}$, I, da Constituição: (...) II fica vedada a dispensa arbitrária ou sem justa causa: (...) b) da empregada gestante, desde a confirmação da gravidez até cinco meses após o parto. In BRASIL. Ato das Disposições Constitucionais Transitórias de 1988. 
Consideradas as garantias tratadas acima, é possível concluir por um efetivo tratamento diferenciado à maternidade.

Entretanto, o problema reside na ausência de condições mínimas a uma parcela da população que não dispõe de uma realidade a lhe assegurar uma maternidade como a Constituição brasileira prevê.

Muitas mulheres, gestantes, em tese abrangidas pelos institutos jurídicos destinados à maternidade, não recebem qualquer proteção por força da exclusão social que sofrem. Não possuem o direito ao trabalho e, consequentemente, não são abarcadas pelas garantias celetistas ou qualquer estabilidade, uma vez que a maioria está atrelada ao trabalho.

Ademais, no que diz respeito à proteção da infância, o diploma legal mais comumente lembrado é o Estatuto da Criança e do Adolescente (ECA). Em nível constitucional, porém, é relevante destacar o artigo $227^{37}$.

Não obstante a existência da inquestionável tutela à infância, é difícil ver a implementação prática daquilo que está previsto na legislação quanto ao particular. Não se verifica a atenção integral, prioritária, que permeia os diplomas citados, oriundos de um processo histórico cuja atuação dos movimentos sociais em prol dos direitos da criança e do adolescente foi marcante, resultando na edição de documentos internacionais que nortearam a constitucionalização da referida proteção e o surgimento da legislação infraconstitucional a ela relativa.

Com efeito, o ponto de convergência entre a proteção à maternidade e à infância resulta na tutela do filho. Por meio do artigo $6^{\circ}$ da Constituição Federal, conferiuse a tutela àqueles que precisam de total atenção do Estado para que possam desenvolver suas capacidades e tenham uma infância digna.

Porém, repise-se, tal tutela deve transcender o âmbito da retórica e passar para a prática diária, atentando-se às dimensões relacionadas a uma infância dotada

\footnotetext{
${ }^{37}$ Artigo 227 - É dever da família, da sociedade e do Estado assegurar à criança, ao adolescente e ao jovem, com absoluta prioridade, o direito à vida, à saúde, à alimentação, à educação, ao lazer, à profissionalização, à cultura, à dignidade, ao respeito, à liberdade e à convivência familiar e comunitária, além de colocá-los a salvo de toda forma de negligência, discriminação, exploração, violência, crueldade e opressão. In BRASIL. Constituição Federal de 1988.
} 
de recursos suficientes ao mencionado desenvolvimento, o que recai sobre a educação, a alimentação, a saúde, a proibição do trabalho infantil, enfim, dialoga, de alguma maneira, com vários direitos sociais, irradiando para pontos cruciais de imprescindível atuação do Estado por meio de suas esferas de poder. Afinal, atentar-se para a infância e a juventude significa projetar um olhar para a sociedade que se pretende construir, de maneira que se possa contar com cidadãos conscientes do seu papel sociopolítico e engajados na transformação da realidade brasileira.

\subsubsection{ASSISTÊNCIA AOS DESAMPARADOS}

Por fim, a assistência aos desamparados é o último item do rol dos direitos sociais estabelecidos pelo artigo $6^{\circ}$ da Constituição Federal.

A assistência aos desamparados é imprescindível numa sociedade tão desigual como a brasileira, na qual a desigualdade é um dos principais traços caracterizadores. Voltar-se aos desamparados é atentar-se àqueles que, em função de todos os problemas culturais e estruturais do país, foram excluídos dos bens mínimos garantidores de uma existência digna.

A ausência de oportunidades e a dificuldade de se afirmar enquanto cidadão participante do processo social são marcantes na realidade dos que são desamparados.

A expressão assistência aos desamparados é, de certa forma, curiosa. Partindo-se da máxima no sentido de que a lei não contém palavras inúteis, indaga-se a razão que teria levado o constituinte a optar pela "assistência aos desamparados" no lugar de promover políticas voltadas ao absoluto término dessa classe subalterna, ou seja, a estabelecer condições suficientes para que não mais existissem desamparados na sociedade brasileira. A conclusão óbvia, ao analisar o texto constitucional, é no sentido de que será promovida a assistência aos desamparados, os quais sempre existirão e o constituinte, na verdade, não pretende retirar deles tal condição, mas apenas prestar assistência. 
Recentemente, a Presidenta Dilma Rousseff editou o Decreto n ${ }^{\circ} 7492$, de 2 de junho de 2011, estabelecendo o "Plano Brasil Sem Miséria". Tal plano visa a resolver a extrema pobreza ${ }^{38}$ existente no Brasil.

Dados do Departamento Intersindical de Estatística e Estudos Socioeconômicos (DIEESE) sinalizam vários indicadores que podem ser relacionados com a noção de extrema pobreza no Brasil: em maio de 2011, a cesta básica mensal em São Paulo custava R\$ 272,98; em Goiânia, R\$ 240,35; em Fortaleza, R\$ 218,01; em João Pessoa, R\$ 200,18 ${ }^{39}$. Em maio de 2011, enquanto o salário mínimo nominal era de R\$ 545,00 , o salário mínimo necessário compreendia o importe de $\mathrm{R} \$ 2.293,31^{40}$.

Nota-se, em breve análise dos dados acima, a latente disparidade entre as regiões metropolitanas observadas, bem como a insuficiência do salário mínimo atual em contraste com o valor suficiente a satisfazer as necessidades para as quais tal salário é estabelecido, conforme preceitua a Constituição Federal, nos termos do art. $7^{\circ}, \mathrm{IV}^{41}$, dispositivo este utilizado como parâmetro, pelo DIEESE, para que se estabeleça o importe necessário acima.

A assistência aos desamparados, ainda que consideradas as ressalvas alhures quanto ao texto constitucional, deve ser promovida pelo Estado levando em conta as disparidades regionais do país, que modificam substancialmente o conceito de extrema

\footnotetext{
${ }^{38}$ O parágrafo único do artigo $2^{\circ}$ do Decreto $7492 / 2011$ classifica, em situação de extrema pobreza, aquela família cuja renda per capita mensal não supere o importe de $\mathrm{R} \$ 70,00$. O questionamento em face da classificação aplicada ao conceito de extrema pobreza se dá na faixa de renda que caracteriza tal situação, pois, em consonância com o artigo $3^{\circ}$, I, do referido Decreto, que dispõe ser uma das diretrizes do Plano a garantia dos direitos sociais, não é razoável crer que apenas aqueles enquadrados na classificação de extrema pobreza pelo dispositivo mencionado inicialmente possuem a necessidade urgente de ter acesso aos direitos sociais mínimos. A verdade é que, ainda que se multiplique cinco vezes a importância mínima de R \$70,00, a realidade de um cidadão em tal faixa de renda e seu acesso aos direitos sociais, em consonância com o disposto no artigo $6^{\circ}$ da Constituição Federal, estará longe do desejável. A extrema pobreza, ou miséria, com a qual se pretende trabalhar, não abarcará a grande faixa de desamparados da sociedade brasileira, relacionando-se apenas com uma parcela de um grupo bem maior.
}

39 DEPARTAMENTO INTERSINDICAL DE ESTATÍSTICA E ESTUDOS SOCIOECONÔMICOS. Quanto se trabalha para comer. Disponível em: <http://www.dieese.org.br/rel/rac/trajun11.xml\#tabelao >. Acesso em 04 jul. 2011.

${ }^{40}$ DEPARTAMENTO INTERSINDICAL DE ESTATÍSTICA E ESTUDOS SOCIOECONÔMICOS. Salário mínimo nominal e necessário. Disponível em: <http://www.dieese.org.br/rel/rac/salminMenu0905.xml>. Acesso em 04 jul. 2011.

41 "Salário mínimo, fixado em lei, nacionalmente unificado, capaz de atender a suas necessidades vitais básicas e às de sua família com moradia, alimentação, educação, saúde, lazer, vestuário, higiene, transporte e previdência social, com reajustes periódicos que lhe preservem o poder aquisitivo, sendo vedada sua vinculação para qualquer fim”. BRASIL. Constituição Federal de 1988. 
pobreza de uma região para a outra, de maneira que a população aguarda a garantia de direitos fundamentais consagrados pela carta constitucional, sendo responsabilidade do Estado promover as mudanças necessárias à redução da enorme desigualdade brasileira e o aniquilamento da situação de extrema pobreza.

\subsection{FUNDAMENTO ÉTICO}

A busca pelo fundamento, no campo das ciências humanas, atribui à perspectiva científica o encontro das razões que constituem a base fundante do objeto cognoscível.

O fundamento ético, por sua vez, está relacionado à busca pelas razões que levam determinadas normas de natureza social a serem cumpridas pelos indivíduos. A esse respeito afirma o Professor Fábio Comparato:

Ora, em matéria ética, o fundamento é um critério ou modelo de vida. $\mathrm{Na}$ língua grega, de onde nos veio o vocábulo, critério é um substantivo ligado ao verbo krinô ( $\kappa \mathrm{v} v \omega)$, empregado em três acepções principais: $1^{\mathrm{a}}$.) julgar, decidir, condenar; $2^{\mathrm{a}}$.) estimar, crer; e $3^{\mathrm{a}}$.) separar, escolher, comparar. Em latim, usava-se o verbo cerno, de onde proveio o nosso discernir. Kpı $\tau$ pıov designa a medida ou padrão de julgamento e, secundariamente, o julgador (juiz ou tribunal) ${ }^{42}$.

As três acepções acima apontadas pelo professor, no contexto da língua grega, podem ser condensadas pela noção atribuída pelo latim, uma vez que discernir implica conhecer o objeto, discriminá-lo ou, ainda, apreender todas as suas características para, enfim, distingui-lo dos demais - e é nesse sentido que se fala em fundamento ético.

Partindo, pois, para o fundamento ético atrelado aos direitos sociais, é possível encontrá-lo no conceito de justiça distributiva.

${ }^{42}$ COMPARATO, Fábio Konder. Ética: direito, moral e religião no mundo moderno. São Paulo: Companhia das Letras, 2006. p. 438. 
Com efeito, compreender a concepção de justiça distributiva implica percorrer os caminhos filosóficos traçados por Aristóteles (Ética a Nicômaco) e Tomás de Aquino (Suma Teológica), cuja síntese é teorizada pelo Professor José Reinaldo de Lima Lopes:

\begin{abstract}
Justiça distributiva é a regra e a virtude da distribuição igual (proporcional) de: (a) coisas comuns (não produzidas por ninguém); (b) coisas produzidas em comum; (c) autoridade e poder - liberdade (que por definição são sociais), com as respectivas responsabilidades e recompensas; (d) incentivos e talentos individuais socialmente relevantes e desejados (embora na sociedade capitalista o talento para fazer dinheiro seja o talento por antinomásia). Neste sentido, a adequada e justa distribuição destes acervos comuns é que propicia o bem comum, aquela condição de realização de bens individuais, a "busca da felicidade" lembrada belamente por Thomas Jefferson na Declaração de Independência ${ }^{43}$.
\end{abstract}

Assim, justiça distributiva lembra o exercício de compensar os bens e vantagens existentes na sociedade, de maneira a evitar a consolidação ou perpetuação de uma realidade desigual entre os indivíduos que nela residem. Quando se fala em desigualdade, é importante lembrar que não implica remeter às diferenças, uma vez que a desigualdade é a situação que priva os indivíduos de verem reconhecida a dignidade intrínseca ao ser humano, característica esta que deve ser respeitada independentemente de qualquer elemento condicional que difira os homens entre si, tal como o gênero, a orientação religiosa, preferência política, etnia, orientação sexual, nacionalidade, enfim, toda característica que leve alguns a se convencerem detentores da faculdade de discriminar a outros que não são do mesmo grupo - e, portanto, diferentes. Nessa lógica é importante distinguir desigualdade de diferença.

Portanto, atribuir à justiça distributiva a condição de fundamento ético dos direitos sociais é justificar a lógica que deve permear a vida humana no seio social, no sentido de que os direitos sociais devem ser vistos como um mecanismo utilizado para minimizar as desigualdades que assolam a sociedade e, causando uma enorme exclusão social, deságuam em inúmeros problemas que tomam proporções maiores. É no contexto de desigualdade que surgem muitos movimentos sociais, vindicando a implementação de

${ }^{43}$ LOPES, José Reinaldo de Lima. Op. cit. p. 127-128. 
políticas públicas voltadas à concretização dos direitos e garantias conferidos pela Constituição Federal, legislação infraconstitucional e até mesmo aqueles oriundos dos diversos tratados e convenções dos quais o Brasil é signatário.

\subsection{FUNDAMENTO AXIOLÓGICO}

O fundamento axiológico, por sua vez, dialoga com os valores que informam os direitos sociais enquanto Direitos Humanos.

Atualmente, não é possível pensar o direito divorciado de valores. $\mathrm{O}$ normativismo proposto por Hans Kelsen não pode ser mais acatado como máxima, como verdadeiro axioma, especialmente considerando a revolução axiológica que a filosofia de Kant causou no pensamento moderno, com todas as proposições permeadas pela consagração de valores.

A concepção tridimensionalista do direito, atribuída ao Professor Miguel Reale, confirmou a afirmação de que os valores estão presentes no âmbito da norma, no sentido de que esta aponta para a esfera do "dever ser", de maneira que o valor informa a normatização que permeia a sociedade, juntamente com os fatos que nela ocorrem rotineiramente.

Conforme mencionado no início deste capítulo, os objetivos que configuraram o lema da Revolução Francesa desencadearam um uso excessivo da liberdade, a ponto de trazer a desigualdade como um contexto comum, e cada vez mais marcante no seio social, assim como um viés nitidamente individualista, no sentido de que se passou a dividir os indivíduos com base no papel que exerciam relativamente aos meios de produção, sendo que seus detentores se aproveitaram da superioridade sócio-políticoeconômica dos demais, explorando-os. Tal individualismo, atrelado à liberdade privada e à noção de isonomia, propiciou o surgimento dos movimentos voltados à conquista de direitos que consagrassem um dos princípios constituintes do lema da Revolução Francesa, qual seja, o da solidariedade. 
A solidariedade, portanto, constitui o fundamento axiológico dos direitos sociais, representando a base motivadora da luta pelo surgimento de direitos baseados numa perspectiva compensatória, diferentemente dos direitos até então existentes, fundamentadas numa lógica de distribuir proporcionalmente os bens e preservar a dignidade humana.

A luta passou a ser, outrossim, permeada pelo objetivo de ver garantida a solidariedade enquanto um verdadeiro dever jurídico.

O Professor Fábio Comparato, acerca do fundamento axiológico em questão, discorre:

A solidariedade prende-se à ideia de responsabilidade de todos pelas carências ou necessidades de qualquer indivíduo ou grupo social. É a transposição, no plano da sociedade política, da obligatio in solidum do direito privado romano ${ }^{44}$.

O plano da solidariedade coloca os indivíduos numa perspectiva de comunhão uns com os outros, uma vez que busca o que é comum a todos eles, dialogando e possibilitando a evolução dos outros fundamentos axiológicos dos Direitos Humanos, que a partir de então estarão em consonância com o sentimento de responsabilidade dos indivíduos inseridos na sociedade.

A solidariedade deriva do sentimento natural do homem de cuidar daqueles que fazem parte do seu grupo. Consagrar tal princípio enquanto dever jurídico é necessário porque afasta a possibilidade de uma massa de indivíduos ser expropriada das vantagens exigíveis pela simples condição humana.

Não se pode ignorar, ainda, a dimensão internacional da solidariedade, consistente no respeito de tal fundamento no âmbito das relações entre os diversos povos, voltados à defesa de bens pertinentes ao interesse comum, respeitando, todavia, a autodeterminação de cada um deles. Obviamente que tal princípio pode ser amplamente difundido e aplicado com mais intensidade no plano internacional, de maneira que os povos devem prestar auxílio aos desfavorecidos, independentemente dos condicionantes políticos, religiosos ou quaisquer outros que possam configurar eventuais divergências ideológicas.

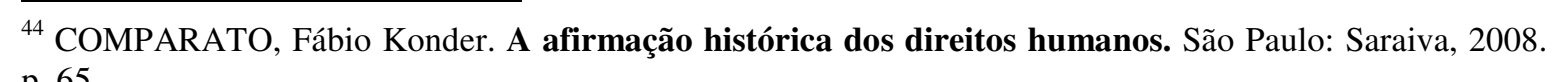
p. 65. 
Ademais, deve-se ressaltar que a Convenção sobre a Diversidade Biológica, de 1992, ao consagrar a conservação da referida diversidade ${ }^{45}$, voltou a preocupação e compromisso dos diversos Estados com a preservação da biodiversidade, de maneira que se atentou às futuras gerações e à condição de que o planeta será usufruído por elas.

Com efeito, a referida convenção representa a razão pela qual se entende também a dimensão intergeracional ${ }^{46}$ da solidariedade.

Nota-se, pois, que a solidariedade irradia sua essência para os diversos planos políticos e sociais nos variados contextos das relações humanas, integrando a razão em que se funda o objetivo de diminuir as desigualdades, com o fim de conceber um projeto de humanização das instituições e valorização do homem pelas diversas instâncias existentes.

Por tal razão, o fundamento axiológico que informa os direitos sociais deve ser considerado para o aprimoramento de todo o arcabouço normativo voltado à lógica compensatória já mencionada.

\footnotetext{
45 "Artigo 1 - Os objetivos desta Convenção, a serem cumpridos de acordo com as disposições pertinentes, são a conservação da diversidade biológica, a utilização sustentável de seus componentes e a repartição justa e equitativa dos benefícios derivados da utilização dos recursos genéticos, mediante, inclusive, o acesso adequado aos recursos genéticos e a transferência adequada de tecnologias pertinentes, levando em conta todos os direitos sobre tais recursos e tecnologias, e mediante financiamento adequado". Idem. op. cit. p. 437.

${ }^{46}$ Idem. Ética: direito, moral e religião no mundo moderno. São Paulo: Companhia das Letras, 2006. p. 580.
} 


\section{DIREITO DO TRABALHO}

O trabalho será considerado, para os fins da presente pesquisa, a principal espécie de direito social - levando em conta o rol previsto no artigo $6^{\circ}$ da Constituição Federal -, uma vez que a violação de direitos humanos relacionados à esfera laboral tem sido cada vez maior, o que chamou a atenção para a realização da presente pesquisa.

O papel que o homem tem desempenhado no campo das relações de trabalho e o valor que o labor ocupa na vida das pessoas são questões em constante metamorfose, intensificadas diariamente com a naturalização do sentimento de que o trabalho é uma característica inata ao ser humano.

Imaginar uma sociedade cujos meios de produção prescindam, em grande parte de tal processo, da atividade humana, tem sido uma possibilidade cada vez mais concreta nos dias atuais.

A integração do homem pela sociedade contemporânea, dotada de uma série de conflitos e contradições, demonstra um caminho deveras dialético acerca do qual não é possível estabelecer qualquer perspectiva sobre a que ponto pretende o homem chegar em relação à sua própria espécie, no sentido de que a cada dia os outrora imagináveis limites são superados por novas formas de exploração.

A automação, como um dos recursos de que se vale para otimizar o processo produtivo e, consequentemente, valorizar o capital no crescimento exponencial do lucro, desempenha papel importantíssimo - talvez o de protagonista - no universo do direito ao trabalho.

Destaque-se a diferença básica entre as expressões direito ao trabalho e Direito do Trabalho; aquela, entendida de maneira romântica como a garantia que possui o homem para buscar não só o mero sustento, mas também a edificação de sua própria vida nos termos consagrados pela sociedade, para atuar no seio social como construtor de um mundo que valorize o esforço e, acima de tudo, a condição humana; esta, relacionada ao campo científico autônomo e interdisciplinar dedicado ao estudo das garantias conferidas não apenas pelo ordenamento jurídico, como por fontes extralegais, aos trabalhadores, de 
forma a estabelecer condições mínimas a serem observadas nos pactos de natureza trabalhista.

Com efeito, embora pareça inicialmente inútil refletir acerca das implicações advindas da relação direito ao trabalho e direito do trabalho, impõe-nos avaliar a própria atuação do homem frente a si mesmo, e mais, o exercício aplicado pelos agentes do direito face às controvérsias que lhes são apresentadas.

\subsection{CONCEITO}

A tarefa de definir o Direito do Trabalho é bastante complexa, haja vista a amplitude exigida para que se esgote o significado de tal ramo da ciência. Vários juristas buscaram tal definição, partindo de perspectivas distintas ou complementares, ou seja, há várias tentativas de se exprimir a essência do Direito do Trabalho.

Considerando as concepções atinentes ao Direito do Trabalho, merece destaque aquela atribuída a Arnaldo Sussekind, segundo o qual:

Direito do Trabalho é o conjunto de princípios e normas, legais e extraestatais, que regem tanto as relações jurídicas, individuais e coletivas, oriundas do contrato de trabalho subordinado e, sob certos aspectos, da relação de trabalho profissional autônomo, como diversas questões conexas de índole social, pertinentes ao bem-estar do trabalhador ${ }^{47}$.

Baseando-se no conceito acima, é possível observar as principais relações do Direito do Trabalho que, enquanto ciência objeto do presente estudo, é norteado por um conjunto de princípios informadores de todo o arcabouço legislativo editado pelo Estado.

${ }^{47}$ SUSSEKIND, Arnaldo. Curso de Direito do Trabalho. 3.ed. Rio de Janeiro: Renovar, 2010. p. 79. 
Todavia, as normas do Direito do Trabalho não são oriundas exclusivamente do aparelho estatal, por meio dos três poderes ${ }^{48}$. Elas também podem advir das normas coletivas (acordos ou convenções coletivos de trabalho, provenientes de negociações) e, até mesmo, das relações contratuais específicas, desde que observadas as condições mínimas estabelecidas no campo normativo.

Vê-se que as relações jurídicas integrantes do campo do Direito do Trabalho não se restringem à perspectiva individual, transcendendo para o âmbito coletivo, de sorte que as entidades sindicais possuem um papel importantíssimo na esfera das relações trabalhistas, consagrado especialmente pelo artigo $8^{\circ}$ da Constituição Federal.

As relações ora mencionadas são especialmente aquelas atinentes ao contrato de trabalho subordinado, entendido como aquele enquadrado nos termos do artigo $3^{\circ}$ da CLT $^{49}$.

Ademais, todas as questões de natureza social que repercutem na vida do trabalhador, ou melhor, do ser humano nesta condição, por óbvio que dialogam com o Direito do Trabalho, o que revela seu caráter eminentemente interdisciplinar.

Não significa dizer, contudo, que o Direito do Trabalho não constitui um ramo autônomo do direito. É inquestionável o necessário e real diálogo que tal ciência trava com outros campos do saber, como a sociologia, economia, psicologia, biologia, entre outros, mas a interdisciplinaridade não anula a autonomia que o Direito do Trabalho possui, uma vez que nele se insere toda a convergência dos campos do saber com vistas à formação do ramo particular.

Outro ponto de divergência que permeia a concepção do Direito do Trabalho diz respeito à classificação enquanto ramo do direito público ou privado.

Aqueles que classificam o Direito do Trabalho como parte do direito privado, o fazem sob a justificativa de que nas relações de trabalho os contratantes estão ajustados por uma relação de coordenação, no sentido de que permanecem no mesmo nível

${ }^{48}$ O Poder Legislativo se encarrega de editar as leis propriamente ditas no campo do Direito do Trabalho; o Poder Executivo possui um poder normativo, sobretudo por meio do Ministério do Trabalho e Emprego, valendo-se de normas regulamentadoras, portarias, resoluções, entre outros; o Poder Judiciário atua nos casos específicos que são submetidos à sua jurisdição, sejam eles de natureza individual ou coletiva, de maneira a solucionar os conflitos materializados.

49 Artigo $3^{\circ}$ - Considera-se empregado toda pessoa física que prestar serviços de natureza não eventual a empregador, sob a dependência deste e mediante salário. In BRASIL. Decreto-lei $n^{\circ} 5452$, de $1^{\circ}$ de maio de 1943. 
ou plano, não havendo, ademais, qualquer envolvimento do Estado no contexto contratual assumido. Consideram, pois, a natureza privada do contrato de trabalho ${ }^{50}$.

Porém, enquanto uns entendem que o Direito do Trabalho integra o direito privado, outros ressaltam a atuação do Estado no estabelecimento de condições mínimas a serem preservadas no âmbito das relações laborais, de maneira que as partes não possuem ampla liberdade para ajustar as cláusulas a serem consignadas. Segundo tal perspectiva, há uma relação triangular havida entre empregado, empregador e o próprio ente estatal, ao qual os dois primeiros estão submetidos, pelo que o Direito do Trabalho é considerado integrante do Direito Público.

Assim, tratadas as principais questões conceituais sobre o Direito do Trabalho, insta asseverar a grande discussão doutrinária existente no particular, devendo ser ressaltado, sobretudo, que o Direito do Trabalho foi concebido sob a ótica dos direitos sociais e, na condição de espécie componente de tal gênero, merece ser sempre interpretado e analisado sob tal perspectiva.

\title{
3.2. EVOLUÇÃO HISTÓRICA NO ORDENAMENTO JURÍDICO BRASILEIRO
}

\begin{abstract}
A história do Direito do Trabalho no ordenamento jurídico brasileiro é relativamente recente, considerando o processo histórico e as transformações ocorridas em face das demandas sociais que surgem no decorrer dele.
\end{abstract}

\footnotetext{
${ }^{50}$ Se a maioria dos defensores da natureza jurídica do Direito do Trabalho como direito público realça o fato de ter ele nascido da intervenção do Estado nas relações de trabalho e da consequente publicização do seu conteúdo fundamental, os partidários da sua classificação como direito privado recordam que as normas legais que lhes correspondem nasceram nos códigos civis, sendo que o instituto básico do novo rumo da ciência jurídica é o contrato de trabalho, cuja natureza jurídica é, indubitavelmente, de direito privado. Assim, o fato de o Direito do Trabalho consubstanciar inúmeras normas irrenunciáveis, por serem de ordem pública - tal como na instituição matrimonial integrante do Direito Civil -, não tem a força suficiente para deslocá-lo para o campo do direito público, embora o coloque na fronteira com esta zona, mas, ainda, em território do direito privado. Sobretudo depois do direito comparado admitir certa flexibilização na aplicação de normas de ordem pública. In SÜSSEKIND, Arnaldo. Op. Cit. p. 102-103.
} 
No Brasil, pode-se afirmar que, com a Constituição do Império (1824), foi possível destacar a influência dos princípios exaltados no período da Revolução Francesa por meio de uma abordagem específica do trabalho e a liberdade de exercê-lo. É possível notar no artigo 179 daquela carta, por meio do inciso $\mathrm{XXIV}^{51}$, representando o marco mais importante do início do Direito do Trabalho no país ${ }^{52}$.

A partir do início do século XX, até por volta de 1930, algumas leis esparsas atinentes ao Direito do Trabalho foram editadas, regulamentando questões como sindicalização, locação de serviços e proteção do trabalho da mulher.

A partir de 1919, porém, com a criação da Organização Internacional do Trabalho (OIT), por meio do Tratado de Versailles, passou-se a ter uma visão voltada a universalizar as questões relativas ao Direito do Trabalho. E o Brasil, integrante da OIT, passou por uma mudança na seara da política trabalhista, preocupando-se com as questões a ela relativas.

Em 1930, o Ministério do Trabalho foi criado, com o posterior advento da Consolidação das Leis do Trabalho (CLT), no ano de 1943, com atuação de Getúlio Vargas.

É importante ressaltar a efetiva participação dos trabalhadores em busca de melhores condições, o que contribuiu para o surgimento da legislação trabalhista no país, especialmente as greves ocorridas em 1919, representando a atuação dos movimentos sociais na luta por direitos nessa lógica social diferenciada.

No âmbito constitucional, a primeira Carta a mencionar a ordem econômica e social foi a de 1934, por meio dos artigos 115 e seguintes, tratando especificamente do Direito do Trabalho no artigo $121^{53}$.

\footnotetext{
51 "Nenhum genero de trabalho, de cultura, industria, ou commercio póde ser prohibido, uma vez que não se opponha aos costumes publicos, á segurança, e saude dos Cidadãos".

52 Antes da Constituição de 1824, é possível encontrar normas esparsas, como uma lei de 1830, regulamentando a prestação de serviços; outra lei em 1837, versando sobre justa causa no âmbito da prestação de serviços pactuada entre colonos; e o Código Comercial (1850), com algumas referências atinentes ao aviso prévio.
}

53 “Artigo 121 - A lei promoverá o amparo da produção e estabelecerá as condições do trabalho, na cidade e nos campos, tendo em vista a proteção social do trabalhador e os interesses econômicos do País. $\S 1^{\circ}-\mathrm{A}$ legislação do trabalho observará os seguintes preceitos, além de outros que colimem melhorar as condições do trabalhador: a) proibição de diferença de salário para um mesmo trabalho, por motivo de idade, sexo, nacionalidade ou estado civil; b) salário mínimo, capaz de satisfazer, conforme as condições de cada região, 
A Constituição de 1937, outorgada por Getúlio Vargas, por meio do artigo $136^{54}$, consagra o trabalho enquanto dever social, passando a tratar de garantias de natureza trabalhista nos artigos seguintes.

Se, por um lado, considerar o trabalho como dever social é valorizar sua importância na vida dos cidadãos e lhe atribuir um caráter obrigatório, por outro, exclui-se a parcela da população que não se insere no grupo de empregados, sobretudo num período de enorme desrespeito às relações de trabalho.

\section{Curioso é observar os termos do artigo $139^{55}$ do último diploma} constitucional mencionado, afirmando a greve como um movimento nocivo "ao trabalho e ao capital”, que contraria “os superiores interesses da produção nacional”, sendo possível ver ainda hoje os resquícios da forma como a greve é considerada no Brasil, não obstante as garantias legais estabelecidas atualmente.

às necessidades normais do trabalhador; c) trabalho diário não excedente de oito horas, reduzíveis, mas só prorrogáveis nos casos previstos em lei; d) proibição de trabalho a menores de 14 anos; de trabalho noturno a menores de 16 e em indústrias insalubres, a menores de 18 anos e a mulheres; e) repouso hebdomadário, de preferência aos domingos; f) férias anuais remuneradas; g) indenização ao trabalhador dispensado sem justa causa; h) assistência médica e sanitária ao trabalhador e à gestante, assegurando a esta descanso antes e depois do parto, sem prejuízo do salário e do emprego, e instituição de previdência, mediante contribuição igual da União, do empregador e do empregado, a favor da velhice, da invalidez, da maternidade e nos casos de acidentes de trabalho ou de morte; i) regulamentação do exercício de todas as profissões; j) reconhecimento das convenções coletivas, de trabalho. $\S 2^{\circ}$ - Para o efeito deste artigo, não há distinção entre o trabalho manual e o trabalho intelectual ou técnico, nem entre os profissionais respectivos. $\S 3^{\circ}-$ Os serviços de amparo à maternidade e à infância, os referentes ao lar e ao trabalho feminino, assim como a fiscalização e a orientação respectivas, serão incumbidos de preferência a mulheres habilitadas. $\S 4^{\circ}-\mathrm{O}$ trabalho agrícola será objeto de regulamentação especial, em que se atenderá, quanto possível, ao disposto neste artigo. Procurar-se-á fixar o homem no campo, cuidar da sua educação rural, e assegurar ao trabalhador nacional a preferência na colonização e aproveitamento das terras públicas. $\S 5^{\circ}$ - A União promoverá, em cooperação com os Estados, a organização de colônias agrícolas, para onde serão encaminhados os habitantes de zonas empobrecidas, que o desejarem, e os sem trabalho. $\S 6^{\circ}$ - A entrada de imigrantes no território nacional sofrerá as restrições necessárias à garantia da integração étnica e capacidade física e civil do imigrante, não podendo, porém, a corrente imigratória de cada país exceder, anualmente, o limite de dois por cento sobre o número total dos respectivos nacionais fixados no Brasil durante os últimos cinqüenta anos. $\S$ $7^{\circ}$ - É vedada a concentração de imigrantes em qualquer ponto do território da União, devendo a lei regular a seleção, localização e assimilação do alienígena. $\S 8^{\circ}$ - Nos acidentes do trabalho em obras públicas da União, dos Estados e dos Municípios, a indenização será feita pela folha de pagamento, dentro de quinze dias depois da sentença, da qual não se admitirá recurso ex -offício".

\footnotetext{
54 “Artigo 136 - O trabalho é um dever social. O trabalho intelectual, técnico e manual tem direito a proteção e solicitude especiais do Estado. A todos é garantido o direito de subsistir mediante o seu trabalho honesto e este, como meio de subsistência do indivíduo, constitui um bem que é dever do Estado proteger, assegurando-lhe condições favoráveis e meios de defesa".

55 “Artigo 139 - Para dirimir os conflitos oriundos das relações entre empregadores e empregados, reguladas na legislação social, é instituída a Justiça do Trabalho, que será regulada em lei e à qual não se aplicam as disposições desta Constituição relativas à competência, ao recrutamento e às prerrogativas da Justiça comum. A greve e o lock-out são declarados recursos antissociais nocivos ao trabalho e ao capital e incompatíveis com os superiores interesses da produção nacional".
} 
A Justiça do Trabalho foi criada em $1^{\circ}$ de maio de 1941, numa fase de efervescência da legislação trabalhista no ordenamento jurídico brasileiro, com o posterior surgimento da Consolidação das Leis do Trabalho (CLT).

A Constituição de 1946 manteve o olhar sobre o trabalho de sua antecessora. $\mathrm{O}$ artigo $145^{56}$ do referido diploma constitucional consagrou o trabalho como obrigação social, e o artigo 157 trouxe algumas garantias mínimas aos trabalhadores. Ademais, o artigo 158 reconheceu o exercício do direito de greve, modificando o tratamento outrora dispensado pelo Estado, mas atribuiu a regulamentação de tal direito a lei a ser editada.

Segundo Arnaldo Sussekind, a Constituição de 1946 representou a melhor Constituição brasileira, integrando a Justiça do Trabalho no âmbito do Poder Judiciário e conferindo várias garantias aos trabalhadores (SUSSEKIND, p. 44-45).

Com efeito, a Constituição de 1967, promulgada com o intuito de manter o aparelhamento nas mãos do regime militar e, portanto, permitir sua continuidade, trouxe, no seu artigo 150, os direitos e garantias individuais, colocando o trabalho como condição da dignidade humana (artigo 157, II) e, ademais, dispôs especificamente sobre os direitos sociais no artigo $158^{57}$, com vinte e um incisos voltados a garantias mínimas no âmbito das relações de trabalho.

\footnotetext{
56 “Artigo 145 - A ordem econômica deve ser organizada conforme os princípios da justiça social, conciliando a liberdade de iniciativa com a valorização do trabalho humano. Parágrafo único - A todos é assegurado trabalho que possibilite existência digna. O trabalho é obrigação social”.
}

57 “Artigo 158 - A Constituição assegura aos trabalhadores os seguintes direitos, além de outros que, nos termos da lei, visem à melhoria, de sua condição social: I - salário mínimo capaz de satisfazer, conforme as condições de cada região, as necessidades normais do trabalhador e de sua família; II - salário-família aos dependentes do trabalhador; III - proibição de diferença de salários e de critérios de admissões por motivo de sexo, cor e estado civil; IV - salário de trabalho noturno superior ao diurno; V - integração do trabalhador na vida e no desenvolvimento da empresa, com participação nos lucros e, excepcionalmente, na gestão, nos casos e condições que forem estabelecidos; VI - duração diária do trabalho não excedente de oito horas, com intervalo para descanso, salvo casos especialmente previstos; VII - repouso semanal remunerado e nos feriados civis e religiosos, de acordo com a tradição local; VIII - férias anuais remuneradas; IX - higiene e segurança do trabalho; $\mathrm{X}$ - proibição de trabalho a menores de doze anos e de trabalho noturno a menores de dezoito anos, em indústrias insalubres a estes e às mulheres; XI - descanso remunerado da gestante, antes e depois do parto, sem prejuízo do emprego e do salário; XII - fixação das percentagens de empregados brasileiros nos serviços públicos dados em concessão e nos estabelecimentos de determinados ramos comerciais e industriais; XIII - estabilidade, com indenização ao trabalhador despedido, ou fundo de garantia equivalente; XIV - reconhecimento das convenções coletivas de trabalho; XV - assistência sanitária, hospitalar e médica preventiva; XVI - previdência social, mediante contribuição da União, do empregador e do empregado, para seguro-desemprego, proteção da maternidade e, nos casos de doença, velhice, invalidez e morte; XVII - seguro obrigatório pelo empregador contra acidentes do trabalho; XVIII - proibição de distinção entre trabalho manual, técnico ou intelectual, ou entre os profissionais respectivos; XIX - colônias 
Por fim, a Constituição Federal de 1988, após um período marcado pelo regime militar, nas instâncias de poder brasileiras desde 1964, trouxe uma nova perspectiva da formulação do Estado para seus indivíduos, consagrando um Estado Democrático de Direito (artigo $1^{\circ}$, caput).

Conforme se depreende do texto constitucional, a própria estruturação da carta, ao colocar primeiramente os direitos e garantias fundamentais, antecedendo a organização do Estado, tem uma justificativa: demonstrar que o Estado existe para servir aos indivíduos, e não o contrário, além do fato de que os direitos fundamentais ganharam uma importância enorme num período representado pela supressão de inúmeras garantias e desrespeito a várias outras. Diante da nova formulação e do conteúdo voltado aos direitos fundamentais, a Constituição Federal de 1988 ficou conhecida como Constituição Cidadã.

O texto constitucional traz, no artigo $7^{\circ}$, após o rol dos direitos sociais (artigo $6^{\circ}$ ), a regulamentação atinente às relações de trabalho, seguido da garantia de associação profissional ou sindical (artigo $8^{\circ}$ ) e do direito de greve (artigo $9^{\circ}$ ), cujo exercício se encontra assegurado.

A carta constitucional de 1988 unificou o salário mínimo no território nacional, sendo que as necessidades básicas a serem satisfeitas foram ampliadas - embora o valor nominal esteja muito distante de atendê-las (vide item 2.1.9). Além disso, o artigo $7^{\circ}$ admitiu o piso salarial no inciso $\mathrm{V}$, consagrou a irredutibilidade salarial e a flexibilizou, sujeitando tal possibilidade apenas mediante previsão expressa por normas coletivas, o que também foi admitido com relação aos turnos ininterruptos de revezamento, sendo possível que as normas coletivas aumentem a jornada de trabalho limitada inicialmente a seis horas.

A história da legislação trabalhista no Brasil é complexa, demandando luta e atuação dos movimentos sociais.

É visível o fato de que o trabalhador brasileiro se encontra protegido por uma grande quantidade de leis, um aparato legislativo considerável surgido no século

de férias e clínicas de repouso, recuperação e convalescença, mantidas pela União, conforme dispuser a lei; XX - aposentadoria para a mulher, aos trinta anos de trabalho, com salário integral; XXI - greve, salvo o disposto no art. $157, \S 7^{\circ}$. $\S 1^{\circ}$ - Nenhuma prestação de serviço de caráter assistencial ou de benefício compreendido na previdência social será criada, majorada ou estendida, sem a correspondente fonte de custeio total. $\S 2^{\circ}$ - A parte da União no custeio dos encargos a que se refere o $\mathrm{n}^{\mathbf{o}}$ XVI deste artigo será atendida mediante dotação orçamentária, ou com o produto de contribuições de previdência arrecadadas, com caráter geral, na forma da lei". 
passado, possibilitando que o Brasil seja um país em destaque no que diz respeito à tutela das relações trabalhistas.

Não implica dizer, todavia, que a existência de leis protetoras implique visualizar uma realidade fática condizente com a previsão normativa, pois o país ainda carece de ver o efetivo cumprimento aos preceitos consagrados pelo ordenamento jurídico.

O trabalho, enquanto direito social em contraste com as garantias integrantes do Direito do Trabalho em si, apresenta uma série de contradições representada pelo desrespeito das obrigações trabalhistas, o surgimento de novas formas de exploração e a própria consagração institucional da exploração do trabalhador, situado num cenário capitalista marcado pelo discurso cínico de considerá-lo um ser humano que merece ter sua dignidade respeitada, mas que na verdade vê nele apenas um número dependente do trabalho para sobreviver.

\subsection{O TRABALHO COMO DIREITO SOCIAL}

Conforme se verifica do estudo até aqui realizado, o tema genérico dos direitos sociais tem sido objeto de inúmeras discussões atualmente. A sociedade está diante de um complexo sistema socioeconômico que a cada dia maximiza as desigualdades, afastando mais as pessoas por conta de questões dele decorrentes.

Primeiramente, cumpre relembrar a origem dos direitos sociais, relacionada a um dos fundamentos axiológicos dos Direitos Humanos, ou seja, a raiz de que emanou o aparato legislativo de discurso de tal ramo do direito.

Os fundamentos mencionados são igualdade, liberdade e solidariedade, merecendo destaque, para a realização do presente estudo, o terceiro deles, uma vez que exerce forte influência sobre o surgimento e a evolução dos direitos sociais.

De forma simples, mas elucidativa, pode-se dizer que a noção de justiça distributiva, enquanto fundamento ético dos direitos sociais, constitui o núcleo informador de tal gênero de direitos. Uma análise da atual situação dos direitos sociais possibilita 
verificar a notável carência de sua efetivação nos dias atuais, especialmente quando se resgata a noção de justiça distributiva que, segundo o Professor Fábio Comparato, corresponde ao fundamento ético da solidariedade.

A justiça distributiva corresponde, de imediato, à ideia de distribuir bens e vantagens existentes e disputados diariamente na sociedade, mas que devem ser transpostos em respeito à dignidade humana.

E, quando menciona tal questão, o Professor Fábio Konder Comparato se reporta aos bens e vantagens entre as classes sociais, importante dado que remete ao conceito preconizado por Karl Marx, segundo o qual tais classes são identificadas pelo papel ocupado pelos indivíduos nas relações de produção, na estrutura que compõe o sistema socioeconômico vigente.

Assim, as classes sociais são, segundo Marx, divididas em burguesia (composta pelos detentores dos meios de produção, que se valem da propriedade para maximizá-la ainda mais) e proletariado (a camada baixa da estrutura codificada pela análise marxista, constituída por aqueles que vendem a mão de obra em troca de uma remuneração, buscando a sobrevivência e a inserção no seio social).

Logo, a solidariedade corresponde ao fundamento que propicia o surgimento dos direitos sociais, conforme anunciado. Percebeu-se que, no decorrer da história, a garantia de liberdade permitiu que se chegasse a um ponto de exploração exacerbada do homem, estabelecendo a desigualdade diante do favorecimento de uns em detrimento do sofrimento de muitos outros, o que requereu a intervenção do Estado para que se possibilitasse a compensação mencionada alhures.

Uma importante forma de se garantirem os direitos sociais é mediante a implementação de políticas públicas com atuação sobre a situação de desigualdade vivenciada no seio social, a fim de conferir garantias mínimas àqueles que não têm acesso a condições dignas de sobrevivência, que estão na base da sociedade e, por isso, compõem a camada desfavorecida, mais fraca e atropelada pelo sistema socioeconômico vigente.

$\mathrm{Na}$ ausência ou insatisfatória atuação do ente estatal, certamente o que se verá (como de fato se vê, em muitos setores) é o distanciamento cada vez maior dos desfavorecidos em relação às condições mínimas de existência que lhes devem ser garantidas, situação esta que propicia uma resposta do grupo a toda a exclusão vivenciada. 
Surge, assim, uma tensão constante norteada pelo conflito de interesses, justificados inclusive por garantias fundamentais contrapostas, ou seja, excluídos e seus opressores (ou aqueles simplesmente deslocados do polo da exclusão) utilizam, em sua defesa, argumentos envolvendo garantias de níveis aparentemente dotados da mesma importância, o que requer um juízo de ponderação para que se encontrem soluções razoáveis.

Os direitos sociais são um gênero que contém o direito ao trabalho (e, por conseguinte, todas as garantias estabelecidas ao trabalhador sob a égide da legislação que cuida das relações de trabalho), o direito à seguridade social (saúde, previdência e assistência social), o direito à educação, à moradia, à proteção da maternidade e à infância e a assistência aos desamparados. Este é o rol elencado pelo art. $6^{\circ}$. da Constituição Federal, que não exaure o que se pode conhecer por direitos sociais vistos sob a ótica acima explanada, mas traduz a escolha a que chegou o constituinte após um processo de intensa participação dos movimentos sociais na luta pela redemocratização do país.

Com efeito, para a análise dos direitos sociais no Brasil, insta realizar uma breve exposição atinente à história e evolução do Estado brasileiro e do ordenamento jurídico que este possui.

A estrutura identificada no ordenamento jurídico brasileiro guarda raízes na chamada Tradição Jurídica Ocidental ${ }^{58}$, da qual emanou todo o complexo normativo que compõe o referido conjunto. A obra de Berman (Direito e Revolução - A Formação da Tradição Jurídica Ocidental) cuida, inicialmente, de uma análise detalhada acerca de cada um dos vocábulos que compõem a expressão ora transcrita, asseverando que "na Tradição Jurídica Ocidental, o Direito é concebido para ser um todo coerente, um sistema integrado, um 'corpo', idealizado para desenvolver-se ao longo do tempo através das gerações e dos séculos" (BERMAN, p. 20).

\footnotetext{
58 "Para falar da Tradição Jurídica Ocidental, é necessário postular um conceito de Direito que seja diferente de um conjunto de regras, que o veja como um processo, como um empreendimento no qual as regras só têm valor no contexto de instituições e procedimentos, valores e modos de pensar (...) É necessário reconhecer que o costume e a equidade são tão integrantes do Direito quanto as normas e as decisões, se se deseja seguir e aceitar a história da Tradição Jurídica Ocidental”. In BERMAN, Harold J. Direito e Revolução - a formação da Tradição Jurídica Ocidental. São Leopoldo: Editora Unisinos, p. 22.
} 
Berman identifica como característica principal da Tradição Jurídica Ocidental a existência do pluralismo jurídico, ou seja, a "coexistência e a competição, na mesma comunidade, de várias jurisdições e sistemas jurídicos" ${ }^{, 59}$ (BERMAN, p. 21).

A Tradição Jurídica Ocidental corresponde, pois, à raiz da formação de todo o corpo normativo que o Estado possui.

É evidente que, ao observar a atual situação dos direitos sociais no Brasil, não obstante se verifique a implementação de políticas públicas em busca da efetivação de tal gênero de direitos, ainda é insuficiente a atuação do Estado. $O$ subdesenvolvimento, característica marcante do país, está intrinsecamente ligado à questão do poder econômico, conforme preceitua o Professor Calixto Salomão Filho:

O poder Econômico, diferentemente dos países hoje desenvolvidos, foi constitutivo das relações econômicas nos países subdesenvolvidos. A maioria, senão a quase totalidade delas, tem sua história intimamente ligada à colonização europeia. E aí está um elemento muito importante a enfatizar. A condição de colônia, muito além da dependência externa, criou estruturas internas de poder no campo econômico que marcaram e marcam todo o processo de desenvolvimento (ou subdesenvolvimento dessas sociedades).

Essa é a razão pela qual parece possível recontar o processo de desenvolvimento a partir das estruturas de poder econômico criadas e da estrutura de distribuição de renda que as acompanha. São elas, de acordo com a tese aqui defendida, as causas principais do subdesenvolvimento de tais países ${ }^{60}$.

59 O pluralismo jurídico corresponde a um fenômeno amplamente estudado no campo da Sociologia do Direito. É possível destacar, na referida seara, a pesquisa realizada por Boaventura de Souza Santos, resultante na obra "Notas sobre a história jurídico-social de Pasárgada", que teve como objeto uma favela localizada no território brasileiro. A pesquisa sociológica revela importantes conclusões para a esfera jurídica, integrando o campo explorado pela Sociologia do Direito. O autor percebe claramente a coexistência do direito oficial, emanado do Estado, e daquele criado pela comunidade que pertence àquele espaço social. Nota-se que a população local se utiliza de meios não oficiais por conta de vários fatores, entre eles a inércia do Estado e a própria ausência de reconhecimento das condições em que vivem. Assim, para aquele espaço, o que realmente tem força é o direito por eles criado, a "lei do mais forte", uma vez que o Estado não chega até eles.

60 SALOMÃo FILHO, Calixto.Monopólio Colonial e Subdesenvolvimento. In BENEVIDES, Maria Victoria de Mesquita et al. Democracia e República: Homenagem a Fábio Konder Comparato. São Paulo: Quartier Latin, 2009. p. 162. 
A partir da transcrição acima se depreende a forte influência da colonização na condição de desenvolvimento do Brasil, marcada principalmente pela rigidez social. O processo mencionado merece destaque por ser considerado uma das origens da desigualdade econômica estabelecida gradativamente no país.

É incontestável o fato de que o Brasil, enquanto colônia de exploração, como a própria expressão informa, cumpriu apenas o papel de servir à metrópole com suas riquezas minerais e seu solo fértil ${ }^{61}$. O baixo custo dos escravos, conforme assevera Blackburn $^{62}$, somado ao grande valor das mercadorias por eles produzidas, criaram a lógica econômica de exploração intensa, sendo que o trabalho exacerbado resultou na inevitável baixa expectativa de vida do escravo. O monopólio colonial, assim, drena a estrutura econômica.

Evidentemente que mudanças ocorreram após o marco da independência, a instauração da república e o processo de industrialização, mas ainda assim o Brasil continua a servir. Neste ponto, aliás, importante mencionar a forte exploração da mão de obra barata fornecida pelo país em face de sua condição precária. Inúmeras multinacionais se estabelecem neste território em virtude de fatores atrativos, como a mão de obra barata e os incentivos fiscais, possibilitando a obtenção de maior lucro, o fortalecimento e o destaque junto ao mercado.

Partindo, pois, para a peculiaridade do Direito do Trabalho, nota-se a inobservância dos direitos trabalhistas e a flagrante deterioração das relações de trabalho, por meio de institutos constituídos pela terceirização, flexibilização, parassubordinação, entre outros.

Destaque-se, ainda, a globalização ${ }^{63}$, que representa um forte fenômeno a interferir na questão das relações laborais e na consagração da desigualdade, sobretudo

61 "Os magníficos resultados financeiros da colonização agrícola do Brasil abriram perspectivas atraentes à
utilização econômica das novas terras. Sem embargo, os espanhóis continuaram concentrados em sua tarefa
de extrair metais preciosos. Ao aumentar a pressão de seus adversários, limitaram-se a reforçar o cordão de
isolamento em torno do seu rico quinhão. As terras onde estavam concentrados se singularizavam na
América por serem densamente povoadas. Na verdade, a empresa colonial espanhola tinha como base a
exploração dessa mão de obra”. In FURTADO, Celso. Formação Econômica do Brasil. São Paulo:
Companhia das Letras, 2007 . p. 37 .
62 BLACKBURN, R. The overthrow of colonial slavery. New York: Verso, 2000. p. 1-31.
63 Para grande parte do mundo, a globalização tal como foi gerida parece um pacto com o diabo. Poucas
pessoas do país ficam mais ricas; as estatísticas do PIB, pelo que valem, parecem melhores, mas os meios de 
no Brasil, território escolhido por inúmeras corporações de ordem internacional que, conforme mencionado, seduzidas principalmente pelo valor da mão de obra e incentivos fiscais, instalam suas filiais e se utilizam de recursos tecnológicos na gestão destas, o que é perfeitamente possível sob a ótica do ordenamento jurídico, merecendo cautela na observação das consequências advindas.

Verifica-se, então, no processo realizado, o desrespeito àquele que oferece sua mão de obra em troca da sobrevivência, ignorado e esquecido pelo detentor e, por vezes, pelo próprio Estado.

Neste diapasão, pondera o Professor José Reinaldo de Lima Lopes:

A asfixia a que foi submetida a classe trabalhadora no Brasil pode ser vista sob dois ângulos: perda de espaço institucional de garantias jurídicas e submissão a condições materiais adversas, especialmente nas grandes cidades. A perda de espaço institucional é exemplar no caso das intervenções nos sindicatos, proibição de greves e fim da estabilidade no emprego. Para reconquistar parcialmente estas garantias não há outra possibilidade de apelo retórico a não ser a declaração universal dos direitos do homem, visto que a ordem jurídica positiva nacional é insuficiente para tanto. O regime militar consegue, paradoxalmente, politizar a questão do trabalhador justamente por diminuir o seu espaço jurídico. Não podendo discutir seus direitos "tecnicamente", "dogmaticamente" ou "juridicamente", a saída é meramente política. Por esta razão os operários chegam em alguns casos a resistir, por algumas horas de indecisão, a acatar sentenças de tribunais do trabalho: é-lhes preciso mostrar que dentro do direito positivado não há espaço para outra solução, exceto os reiterados julgamentos de ilegalidade das greves. Esta asfixia do quadro jurídico positivo permite ligar diretamente os direitos humanos às lutas sindicais ${ }^{64}$.

Convém mencionar, ao ensejo da atuação estatal de maneira geral, a atuação particular desempenhada pelo Poder Judiciário, que de certa forma contribui para a ineficácia do direito social do trabalho. Para demonstrar tal situação, basta que se verifique a política de conciliação implementada nos últimos tempos.

vida e os valores básicos estão ameaçados. Para algumas partes do mundo, os ganhos são ainda mais tênues; os custos, mais palpáveis. A integração mais estreita à economia global causou maior volatilidade e insegurança, e mais desigualdade. E chegou mesmo a ameaçar os valores fundamentais. As coisas não devem ser assim. Podemos fazer a globalização funcionar, não apenas para os ricos e poderosos, mas para todos, inclusive aqueles que vivem nos países mais pobres. A tarefa será longa e árdua. In STIGLITZ, Joseph E. Globalização: como dar certo. Trad.: Pedro Maia Soares. São Paulo: Companhia das Letras, 2007. p. 441. ${ }^{64}$ LOPES, José Reinaldo de Lima. Op. cit. p. 37-38. 
Não se coloca, aqui, em absoluto, que o acordo não seja uma forma razoável de solucionar o processo e satisfazer, concomitantemente, o interesse dos litigantes.

Ademais, deve-se considerar que a conciliação também constitui importante saída diante de um Poder exacerbado de processos, com déficit de servidores e juízes e que tem uma demanda cada vez maior, implicando consequentemente na demora processual, o que por si só configura uma situação de injustiça.

Todavia, é importante ter muita cautela diante da intensificação praticada ultimamente, por meio de inúmeros informes colocados na imprensa, demonstrando que este foi o caminho mais fácil encontrado pelo Estado, quando na verdade deveria ter investido na estrutura oferecida aos jurisdicionados, que são os últimos considerados em meio a tantos dados estatísticos, competição para o alcance das várias metas criadas, ocupando o papel de marionetes de um sistema permeado pela hipocrisia.

Com efeito, atualmente a inobservância da legislação trabalhista é uma vantagem aos empregadores, pois com a política aplicada é bem possível que, numa causa líquida em que são pleiteadas verbas rescisórias incontroversas no importe de $\mathrm{R} \$ 10.000,00$, seja avençada a importância de $\mathrm{R} \$ 2.000,00$ para quitação do processo e do extinto contrato de trabalho. $\mathrm{O}$ empregado, diante da miserabilidade notória e comum à maioria da sociedade, vê uma oportunidade de garantir o alimento à sua família. $\mathrm{O}$ empregador considera o caráter lucrativo da avença, sobretudo porque pode parcelar o acordo e estará isento de custas (o que é comum, dependendo da fase processual e do entendimento do juiz que homologa o pacto). $\mathrm{O}$ magistrado, a quem incumbe o exercício de contribuir para a consecução de justiça social, entre várias circunstâncias, vê-se diante de dois importantes detalhes: primeiro, o fato da necessidade urgente do empregado, que está "ciente" dos riscos e afirma estar satisfeito com o acordo; segundo, a questão da solução da demanda, que interferirá nos dados estatísticos prestados mensalmente, significando a concretização da política encampada e, além disso, o fato de que sua mesa, cheia de reclamações, contará com um processo a menos. Aos olhos de todos, uma solução aparentemente resolvida, sobretudo sob o aspecto jurídico!

Multiplique-se a situação acima exposta pelos inúmeros casos semelhantes praticados diariamente no território brasileiro. É duvidoso o fato de que essa 
seja a justiça social, particularmente relativa ao trabalho, pela qual a sociedade tanto anseia.

Analisando outro aspecto da atuação do Poder Judiciário quanto ao tema em questão, relativamente à terceirização, tem-se a edição da Súmula 331 pelo Tribunal Superior do Trabalho ${ }^{65}$, especialmente nos itens III e IV, que também configura uma forma de consagração da exploração.

Afinal, a terceirização, como se vê nos dias atuais, é uma forma utilizada pelas empresas com o fim de desoneração dos encargos trabalhistas previstos em lei. Retiram-se dos empregados os direitos concedidos aos funcionários ligados à denominada atividade-fim, ou seja, discriminam-nos de garantias que, na maioria das vezes, são melhores, além de deixá-los à mercê de empresas insolventes, que surgem e são encerradas do dia para a noite.

Assim, ao ajuizar a reclamação trabalhista, o empregado já se depara imediatamente com um grande empecilho: a citação. Na maioria das vezes, tais empresas simplesmente desaparecem. Isso desconsiderando aqueles que sequer ajuízam a reclamatória, e que geralmente são desligados das empresas sem o recebimento de qualquer verba rescisória.

Todavia, a empresa tomadora de serviço, aos olhos do Judiciário, será responsabilizada, via de regra - e se a terceirização for lícita, ou seja, envolver atividademeio da tomadora - nos termos da Súmula 331 do TST, e tentará de todas as formas se desonerar dos encargos processuais, com questionamentos até a fase executória, podendo citar, a título de exemplo, o benefício de ordem, tão invocado em sede de execução,

\footnotetext{
${ }^{65}$ Súmula 331 do TST: I - A contratação de trabalhadores por empresa interposta é ilegal, formando-se o vínculo diretamente com o tomador dos serviços, salvo no caso de trabalho temporário (Lei ${ }^{\circ}$ 6.019, de 03.01.1974). II - A contratação irregular de trabalhador, mediante empresa interposta, não gera vínculo de emprego com os órgãos da Administração Pública direta, indireta ou fundacional (art. 37, II, da CF/1988). III - Não forma vínculo de emprego com o tomador a contratação de serviços de vigilância (Lei $n^{\circ} 7.102$, de 20.06.1983) e de conservação e limpeza, bem como a de serviços especializados ligados à atividade-meio do tomador, desde que inexistente a pessoalidade e a subordinação direta. IV - O inadimplemento das obrigações trabalhistas, por parte do empregador, implica a responsabilidade subsidiária do tomador dos serviços quanto àquelas obrigações, desde que haja participado da relação processual e conste também do título executivo judicial. V - Os entes integrantes da Administração Pública direta e indireta respondem subsidiariamente, nas mesmas condições do item IV, caso evidenciada a sua conduta culposa no cumprimento das obrigações da Lei n. ${ }^{\circ}$ 8.666, de 21.06.1993, especialmente na fiscalização do cumprimento das obrigações contratuais e legais da prestadora de serviço como empregadora. A aludida responsabilidade não decorre de mero inadimplemento das obrigações trabalhistas assumidas pela empresa regularmente contratada. VI - A responsabilidade subsidiária do tomador de serviços abrange todas as verbas decorrentes da condenação referentes ao período da prestação laboral.
} 
impedindo que o processo prossiga por uma discussão que, se não fosse a atuação do Judiciário na elaboração de um entendimento que ignora o trabalhador, seria resolvido em menos tempo.

Oportuno mencionar, relativamente à atuação dos magistrados, o posicionamento de Posner:

\begin{abstract}
Apesar das aparências, não há muito que os juízes possam fazer para redistribuir a riqueza. Por exemplo, uma regra que facilite aos inquilinos pobres o rompimento dos contratos de locação com os senhorios ricos irá induzir estes últimos a aumentar os aluguéis a fim de suportar o impacto dos custos mais altos impostos pela regra, e os inquilinos vão suportar o peso dos custos elevados. $\mathrm{Na}$ verdade, a principal redistribuição realizada por tal regra pode abranger desde o inquilino prudente e responsável, que pode obter pouca ou nenhuma vantagem dos direitos jurídicos adicionais a ser usados contra os senhorios - direitos que podem permitir que um inquilino evite ou adie o despejo pelo não-pagamento do aluguel -, até o inquilino inconsequente. Trata-se de uma redistribuição extravagante. Porém, devido a seu poder de tributação e de alocação de recursos, o legislativo dispõe de instrumentos poderosos para redistribuir a riqueza. Desse modo, uma divisão eficiente do trabalho entre os poderes legislativo e judiciário leva o legislativo a concentrar-se no atendimento às exigências de distribuição de riqueza, por parte dos grupos de interesses, e o judiciário a atender à grande demanda social por regras eficientes que cuidem da segurança, da propriedade e das transações. Embora haja outros objetivos possíveis de ação judicial além da eficiência e da redistribuição, muitos deles (diferentes concepções de "equidade" e "justiça") são rótulos para maximização da riqueza ou para a redistribuição que favoreça os poderosos grupos de interesses; ou então eles são demasiados controversos numa sociedade heterogênea, demasiado ad hoc ou insuficientemente desenvolvidos para oferecer as bases sólidas às decisões dos juízes que desejam ter uma reputação de objetividade e imparcialidade ${ }^{66}$.
\end{abstract}

Se o papel da redistribuição da riqueza não pode ser, dentro dos seus limites, desempenhado pelos magistrados, dificulta-se a busca de uma solução que deve, necessariamente, partir do órgão estatal. Afinal de contas, a intervenção do Estado mediante suas diversas formas de atuação, constitui o ponto de partida para que se possa efetivar a mencionada compensação entre bens e riquezas, com a consequente concretização de justiça social.

${ }^{66}$ POSNER, Richard A. Problemas de Filosofia do Direito. São Paulo: Martins Fontes, 2007. p. 483. 
Diante do contexto vivenciado, vê-se a premente necessidade de se mudar o direito aplicado, uma vez que não basta apenas aplicá-lo, sendo necessário encontrar remédios estruturais à verdadeira efetivação do Direito do Trabalho visto sob a ótica de direito social e, portanto, integrante do rol dos direitos humanos.

Com efeito, considerando que a estrutura econômica precedeu o Estado no caso do Brasil, este ente foi afetado por tal estrutura quando do seu surgimento. Tal dado deve ser considerado para a leitura do recorte ora estabelecido; afinal, o Estado foi formatado para servir à estrutura econômica, tornando-se instrumento para atendê-la, o que estimula a perpetuação de monopólio.

Assim, os estudos apontam que o direito é um instrumental aplicado às estruturas dominantes, sendo difícil não se admitir certo determinismo histórico, quando valores podem ser formados em função de estruturas econômicas.

Não basta uma visão meramente compensatória, insuficiente aos objetivos de que cuidam os direitos sociais. Precisa-se de uma mudança metodológica do direito, sendo importante realizar um filtro entre as estruturas econômica e social. É necessário, pois, criar um procedimento econômico inclusivo.

E tal realidade não é diferente no que diz respeito às relações de trabalho, uma vez que estão intrinsecamente atreladas às questões estruturais. Ora, basta partir da premissa de transformação do escravo em trabalhador assalariado e, assim, depara-se com um desafio na seara dos direitos humanos de forma geral, pois a exclusão social resultante do processo produtivo requer a implementação de políticas públicas que efetivem o discurso dos direitos sociais.

O grande obstáculo daqueles que operam o Direito do Trabalho talvez seja o de humanizar, por meio da aplicação efetiva dos princípios dos direitos humanos, a lógica desumana que tem sido perpetrada nas relações laborais, resultando em total desrespeito às garantias conferidas aos empregados. O Direito do Trabalho pode ser utilizado como efetiva ferramenta para promover tal transformação, considerando a perspectiva dos direitos humanos como importante subsídio. 


\section{MODERNIDADE LÍQUIDA}

Antes de passar especificamente ao estudo da modernidade líquida, é importante traçar o perfil do sociólogo que apresentou a proposta teórica em questão.

O sociólogo polonês Zygmunt Bauman, professor emérito das universidades de Leeds e Varsóvia, iniciou sua carreira nesta última, partindo para o Canadá, Estados Unidos da América e Austrália, após ter seus escritos censurados. Ao ingressar na Universidade de Leeds, desenvolveu grande parte do pensamento sociológico mundialmente reconhecido. Dos prêmios que recebeu, destaca-se o Amalfi, conquistado em 1989 e atribuído à obra Modernidade e Holocausto, considerada a melhor da sociologia de toda a Europa, podendo citar, ainda, o prêmio Theodor W. Adorno, datado de 1998, pelo conjunto de sua obra ao refletir sobre a "ética pós-moderna".

Entretanto, por meio de seu estudo dedicado às questões sociológicas, Bauman desenvolveu importante diálogo com outros campos do saber, dos quais se destaca a filosofia, especialmente nas tensões entre coletividade e individualidade, segurança e liberdade ou até mesmo quanto ao conceito de felicidade, questionamentos que não apenas tangenciaram, mas adentraram pontualmente em tensões reflexivas que representam verdadeiro diálogo com o referido campo do conhecimento.

De todo o conjunto de sua obra, do qual mais de dezesseis títulos foram publicados no Brasil, destacam-se: "Modernidade e Holocausto", "O mal-estar da pósmodernidade", "Modernidade e Ambivalência", "Modernidade Líquida", "Comunidade" e "Globalização: as consequências humanas".

Bauman constrói seu pensamento sociológico partindo da perspectiva identificada no contexto de modernidade líquida, denominação atribuída por ele mesmo em diálogo com a noção de pós-modernidade.

Com efeito, o estudo acerca da modernidade líquida passará pelas relações da teoria sociológica com o âmbito do trabalho, investigando o horizonte traçado por Bauman relativamente aos direitos humanos, uma vez que dele emergem vários pontos inerentes ao estudo dos mencionados direitos.

Por fim, pretende-se demonstrar, nesta reflexão, o caráter utilitarista ou instrumental dos direitos humanos segundo o pensamento sociológico de Bauman, 
utilizando como base as obras "Modernidade Líquida", "A Arte da Vida" e "Vida a Crédito", a fim de se estabelecer, portanto, o fundamento filosófico dos direitos humanos sob a perspectiva do autor em questão.

\subsection{A PROPOSTA SOCIOLÓGICA DE ZYGMUNT BAUMAN}

Zygmunt Bauman traça uma perspectiva dicotômica entre modernidade sólida ou pesada e modernidade líquida ou leve, partindo de uma análise da modernidade sob a ótica da questão temporal, afirmando pela ocorrência de uma emancipação do tempo em relação ao espaço, uma vez que o homem passou a administrar o tempo de maneira a satisfazer seus anseios lucrativos em todos os sentidos da vida, num contexto de produção contínua voltada à constante otimização da mencionada questão temporal.

A administração do tempo já estava presente na modernidade sólida, mas ganha nova roupagem no contexto fluido de modernidade, uma vez que a emancipação com relação ao espaço constitui um novo cenário que potencializa a instrumentalização do que é temporal. Nesse sentido:

Na era do hardware, da modernidade pesada, que nos termos de Max Weber era também a era da racionalidade instrumental, o tempo era o meio que precisava ser administrado prudentemente para que o retorno de valor, que era o espaço, pudesse ser maximizado; na era do software, da modernidade leve, a eficácia do tempo como meio de alcançar valor tende a aproximar-se do infinito, com o efeito paradoxal de nivelar por cima (ou, antes, por baixo) o valor de todas as unidades no campo dos objetivos potenciais $^{67}$.

A modernidade líquida, conforme descrito por Bauman, anuncia um período de desregulamentação, de fragilidade dos laços humanos e de privatização das tarefas e deveres modernizantes.

As relações humanas, sob a égide da modernidade líquida, tendem a uma superficialidade inerente que leva os indivíduos a estabelecer e romper

\footnotetext{
${ }^{67}$ BAUMAN, Zigmunt. Modernidade Líquida. Tradução de Plínio Dentzien. Rio de Janeiro: Zahar, 2001. p. 137.
} 
relacionamentos rapidamente, uma vez que se verifica uma espécie de descartabilidade em tal contexto.

Vivencia-se um processo de constante e indeterminante individualização, uma vez que se estabelece por novas formas de acordo com os resultados agregados, a fim de constituir uma espécie de autonomia denominada de jure, a qual não corresponde necessariamente ao concomitante e efetivo estabelecimento de uma autonomia de fato.

A construção da individualização, aliás, não está atrelada ao exercício da plena liberdade, uma vez que o processo de individualização está relacionado à forte atuação marcada por um viés ideológico, pano de fundo que acarreta aos indivíduos a necessidade de voltar-se constantemente à transformação para que se tornem o que já são, pois são bombardeados por inúmeros conceitos que lhes impõem tais necessidades.

A distância, porém, dos indivíduos no plano de jure em relação ao plano de fato é cada vez maior, pois os desejos que manifestam são cada vez mais impostos, não representando verdadeiramente suas decisões.

Com efeito, a problemática da individualização de fato sugere uma função da Política para contribuir e, inclusive, possibilitar, a efetivação de tal processo. A referida assertiva destaca um novo dilema, haja vista que há, segundo Bauman, uma situação de verdadeiro divórcio entre poder e política no contexto de modernidade líquida.

Ao apontar para a principal contradição da modernidade líquida, Bauman sugere:

O abismo que se abre entre o direito à autoafirmação e a capacidade de controlar as situações sociais que podem tornar essa autoafirmação algo factível ou irrealista parece ser a principal contradição da modernidade fluida - contradição que, por tentativa e erro, reflexão crítica e experimentação corajosa, precisamos aprender a manejar coletivamente ${ }^{68}$.

Assim, a modernidade líquida, fluida, regida pela instabilidade que constitui um cenário social plasmódico - marcado pela indiferença às questões sociais, aos inúmeros problemas que residem na sociedade e, assim, irradiam para toda a coletividade -, fortalece ainda mais a transformação do homem em mercadoria. E como mercadoria,

\footnotetext{
${ }^{68}$ Idem. op. cit. p. 47.
} 
permeado pela ideologia que o bombardeia diariamente, o homem se convence de sua condição cada vez mais distante do humano, vivenciando um conflito na tentativa de se reconhecer e tornar-se o que já é de sua natureza, mas foi perdido e desnaturado ao longo do tempo.

O multiculturalismo se insere na obra de Zygmunt Bauman como outro ponto existente na modernidade líquida, que de certa maneira repercute na questão dos direitos humanos.

De fato, Zygmunt Bauman vê o multiculturalismo como forte instrumento para manter a incerteza que reside no mundo sobre quais valores devem ser consagrados e mantidos na sociedade, apontando pela "ideologia do fim da ideologia". O sociólogo aponta o problema, afirmando que o multiculturalismo:

É um manifesto a favor da reconciliação: as novas realidades não são enfrentadas nem contestadas, há uma rendição a elas - que as coisas (sujeitos humanos, suas escolhas e o destino que se segue a elas) "sigam seu próprio curso". É também um produto do arremedo de um mundo marcado pelo desengajamento como principal estratégia do poder e pela substituição das normas pela variedade e pelo excesso. Se a realidade não for questionada e se supuser que não deixa alternativas, só podemos torná-la aceitável replicando seu padrão em nossa própria maneira de viver $^{69}$.

Bauman atribui, ainda, ao multiculturalismo o papel de promover, implicitamente, um discurso de indiferença ou descaso quanto à diversidade, sob o pretexto da tolerância, o que acarreta um caráter conservador que tende a afastar e não a integrar as diferenças culturais.

O posicionamento de Bauman com relação ao multiculturalismo demonstra, de certa forma, um aspecto que foge do contexto fluido que, segundo ele, permeia a sociedade contemporânea. Afinal, o estado físico do conceito de multiculturalismo certamente foge da liquidez afirmada em sua obra, haja vista que tal discurso é aplicado pelos intelectuais como mecanismo para esconder ou disfarçar a incompetência de interpretar as sociedades do atual contexto.

Outrossim, o problema que o multiculturalismo representa à temática dos direitos humanos reside na possibilidade de, mediante o discurso de solução para

${ }^{69}$ Idem. op. cit. p. 120. 
compreender a diversidade cultural que permeia a sociedade contemporânea e todas as consequências que tal situação acarreta, a sociedade manter-se inerte (e, portanto, radicalmente sólido o que, em tese, estaria sob um contexto de total fluidez) diante da incapacidade de escolha dos valores ao denominar uma sociedade de multicultural.

Desta forma, é possível identificar entraves à autoafirmação, especialmente quando se fala na construção das minorias e na proclamada, porém não garantida, liberdade de escolha, que não é efetivamente assegurada, embora o discurso sinalize para o sentido oposto, dando a falsa sensação de que os homens são livres quando, na verdade, estão cada vez mais presos.

Outro ponto fundamental da obra de Bauman, encontrado especialmente em "A Arte da Vida", diz respeito à felicidade.

Bauman assinala que, da mesma forma que se assiste a uma espécie de coerção a ser livre, o que não possibilita, por óbvio, a efetiva liberdade, vivencia-se um caráter obrigatório de se buscar a felicidade.

Os ingredientes da felicidade, porém, são ditados diariamente na vida e na forma como as pessoas devem conduzir seus atos, sendo a condição de consumidores um dos pontos principais que conduzem à falsa sensação de felicidade das pessoas.

Analisando a falsa sensação de liberdade, liberdade esta que é conduzida para comprar e, assim, fazer com que os homens exerçam a função de consumidores, satisfazendo os anseios que lhes são construídos diariamente, Bauman afirma:

\footnotetext{
Numa sociedade sinóptica de viciados em comprar/assistir, os pobres não podem desviar os olhos; não há mais para onde olhar. Quanto maior a liberdade na tela e quanto mais sedutoras as tentações que emanam das vitrines, e mais profundo o sentido da realidade empobrecida, tanto mais irresistível se torna o desejo de experimentar, ainda que por um momento fugaz, o êxtase da escolha. Quanto mais escolha parecem ter os ricos, tanto mais a vida sem escolha parece insuportável para todos ${ }^{70}$.
}

O conceito de felicidade é atribuído a condições determinadas a satisfazer uma lógica voltada ao poder aquisitivo, à possibilidade não apenas de comprar, mas de manter-se atualizado e não pertencer ao rol dos que foram atingidos pela noção de

${ }^{70}$ Idem. op. cit. p. 104. 
obsolescência programada, o constante e imediato retorno à desatualização em face das novidades que são lançadas diariamente para selecionar aqueles que, mesmo diante de um "poder de escolha”, curvam-se aos ditames consagrados pelo mercado.

As escolhas existem, mas é preciso esclarecer que não são feitas pelos consumidores, pois antes deles há um trabalho mercadológico voltado a conquistá-los e seduzi-los ao exorcismo de consumir os padrões ditados.

Não obstante, a felicidade é considerada por Bauman como um estado inatingível, uma vez que se modifica constantemente, pois os padrões ditados nunca são satisfeitos com os recursos de que os homens dispõem para tanto (e tal é a lógica, de escapar sempre da capacidade dos indivíduos no exercício da felicidade).

Assim, o homem narra sua trajetória mediante os padrões impostos, voltando-se à individualização, à ausência de preocupação com o outro e ao descomprometimento com as questões que atingem a sociedade, num constante processo de desengajamento que, ao colocá-lo diante de um cenário liquefeito, torna a sua própria vida inconsistente, líquida, plasmódica e vulnerável.

\subsection{O TRABALHO NA MODERNIDADE LÍQUIDA}

"A vida de trabalho está saturada de incertezas"71: a frase curta e objetiva de Bauman, na tentativa de contextualizar a realidade das relações de trabalho, traz à tona questões importantes que dialogam com a modernidade líquida por ele concebida enquanto teoria.

As incertezas do trabalho estão cada vez mais presentes na sociedade. Um indivíduo preocupado com sua colocação profissional pagará muito alto (se assim puder) para conseguir seu espaço no mercado de trabalho, pois encontrará uma enorme quantidade de concorrentes dispostos a trabalhar nas mesmas condições que ele, dedicando mais tempo à jornada de trabalho, aceitando, inclusive, termos contratuais a eles prejudiciais para conquistar o direito ao labor.

${ }^{71}$ Idem. op. cit. p. 169. 
A política, por parte dos empregadores, de conferir aos trabalhadores o necessário poder aquisitivo e vários outros benefícios para retê-los no contexto da atividade econômica do empregador, é justificada pela intenção e necessidade de contar com um empregado que dedicará toda a sua trajetória profissional àquele empregador, como o tradicional modelo de casamento, no qual os cônjuges vivem "felizes para sempre”. São as contradições permeando a modernidade líquida!

Os mecanismos utilizados pelos empregadores vão desde os discursos hipócritas que os consideram "colaboradores" até o "formidável" desejo de contar com alguém que verdadeiramente "vista a camisa da empresa".

Aliás, é importante observar o emprego do termo "colaborador" no âmbito laboral. Tal vocábulo é amplamente distorcido com a finalidade de causar a falsa impressão ao empregado de que ele não é considerado na condição que o típico vínculo empregatício o coloca. Como parte integrante e atuante no contexto do empregador, chamar o empregado de "colaborador" retira-lhe a sensação de que sua mão de obra passa por constante exploração, amenizando sua posição inferior na relação laboral, como se todos estivessem juntos para a consecução de um mesmo objetivo e, ao final, fossem igualmente juntos colher todos os frutos que os esforços envidados trouxessem, o que não passa de verdadeira ilusão.

Juntamente com a modernidade líquida veio a consolidação de um pensamento no sentido de que o empregado firma o compromisso, perante o seu empregador, de assumir com ele os riscos da atividade desenvolvida. Facilmente identificável por meio de discursos que colocam tal compromisso nas entrelinhas, tal como aquele ora mencionado, a assunção do papel de "colaborador" do processo é exclusivamente para incentivar o empregado a se desdobrar na sua atuação dentro do processo produtivo, mas não significa dizer que, juntamente com os ônus, virão os bônus que a atividade auferir.

É possível diagnosticar várias contradições no âmbito laboral da modernidade líquida, e Bauman registra criticamente seu olhar para as consequências que a globalização traz ao trabalho.

A precarização das condições de trabalho, mediante institutos tão exaltados como a flexibilização das garantias trabalhistas e a terceirização de certas 
atividades pertinentes ao processo produtivo, encontra de outro lado uma política hodiernamente praticada pelos empregadores com o intuito de inovar, valorizar ou otimizar o mesmo processo produtivo para obter colocação no mercado bem sucedida, de forma que buscam a confiança e verdadeiro comprometimento dos empregados no contexto de suas atividades. Reside, aí, uma contradição, haja vista que o empregado permanece totalmente submisso ao principal interesse de seu empregador em ver o capital investido multiplicado cada vez mais, sendo que àquele que participa da ação multiplicadora, fornecendo sua mão de obra, cabe apenas se desdobrar para colaborar com a satisfação dos objetivos patronais.

Ao apontar a ética do trabalho residente na promoção do trabalho pelo trabalho ${ }^{72}$, Bauman identifica a atividade laboral como um meio utilizado para procrastinar o gozo, que permanece indefinido.

O trabalho pelo trabalho é uma constatação que há muito poderia ter sido feita. O homem não nasceu para o trabalho nos termos que se conhece, mas passou por um processo de naturalização desse sentimento, o que foi intensificado por força do advento da era industrial.

A realidade brasileira apresenta a média de seus cidadãos desesperados à procura de colocação profissional e, quando a tem, continuam com o mesmo espírito inquieto em busca de se manter ou alcançar a ascensão no campo em que atuam, pois o trabalho é uma condição de sobrevivência e de afirmação enquanto cidadão no contexto de modernidade líquida. $\mathrm{O}$ trabalho é o principal meio que viabiliza ao cidadão afirmar-se enquanto consumidor perfeito.

Prosseguindo no raciocínio acerca do sentido do trabalho na modernidade líquida, o trabalho, segundo Zygmunt Bauman:

Adquiriu - ao lado de outras atividades da vida - uma significação principalmente estética. Espera-se que seja satisfatório por si mesmo e em si mesmo, e não mais medido pelos efeitos genuínos ou possíveis que traz a nossos semelhantes na humanidade ou ao poder da nação e do país, e menos ainda à bem-aventurança das futuras gerações. Poucas pessoas apenas - e mesmo assim raramente - podem reivindicar privilégio, prestígio ou honra pela importância e benefício comum gerados pelo trabalho que realizam. Raramente se espera que o trabalho "enobreça" os que o fazem, fazendo deles "seres humanos melhores", e raramente

72 Devido à sua ambivalência, a procrastinação alimenta duas tendências opostas. Uma leva à ética do trabalho, que estimula a troca de lugares entre meios e fins e proclama a virtude do trabalho pelo trabalho, o adiamento do gozo como um valor em si mesmo, e, valor mais refinado do que os valores que se destinava a servir, a ética do trabalho insiste em que o adiamento se estenda indefinidamente. In Idem. op. cit. p. 181. 
alguém é admirado e elogiado por isso. A pessoa é medida e avaliada por sua capacidade de entreter e alegrar, satisfazendo não tanto a vocação ética do produtor e criador quanto as necessidades e desejos estéticos do consumidor, que procura sensações e coleciona experiências ${ }^{73}$.

O contexto de modernidade líquida exerce total influência sobre as relações laborais. A insegurança típica da realidade liquefeita estabelece condições favoráveis à precarização do trabalho, conforme já anunciado anteriormente, desaguando em desrespeito às garantias mínimas estabelecidas pelo ordenamento jurídico, informalidade, terceirização, subcontratação, flexibilização e desemprego.

Nota-se a separação entre capital e trabalho no âmbito do espaço, no sentido de que o trabalho é exercido em local específico, predeterminado e, portanto, via de regra fixo. O capital, por sua vez, transita facilmente em nível mundial, partindo para uma dimensão completamente distinta daquela em que reside o trabalho.

Assim, a relação de trabalho é vantajosa apenas para quem compra a mão de obra, pois a desregulamentação e a dissociação acima mencionada propiciam maior lucratividade, desaguando na grande possibilidade de acúmulo de riqueza.

Os laços nas relações de trabalho estão absolutamente enfraquecidos, fragilizados que foram pelo contexto de modernidade líquida, sejam eles no âmbito das relações entre empregadores e empregados ou entre os próprios empregados.

\subsection{SENTIDO FILOSÓFICO DOS DIREITOS HUMANOS EM ZYGMUNT BAUMAN}

A modernidade líquida faz com que a realidade social esteja permeada pela desregulamentação, insegurança, privatização e consumismo. O quadro em que se vê tal contexto é aquele em que se insere a lógica dos direitos humanos.

\footnotetext{
${ }^{73}$ Idem. op. cit. p. 160-161.
} 
Bauman afirma:

Demandas por reconhecimento tendem hoje em dia a ser apresentadas sem referência à justiça distributiva. Quando isso acontece, suposições tácitas também são feitas, mas, ao contrário das suposições de Weber, elas são contrafactuais. O que se supõe, afinal, é que ter assegurado legalmente o direito de escolha significa ser livre para escolher - o que não é o caso. No caminho de uma versão "culturalista" do direito humano ao reconhecimento, a tarefa não realizada do direito humano ao bem-estar e a uma vida vivida com dignidade se perdeu ${ }^{74}$.

Embora os Direitos Humanos não sejam objeto de um estudo específico na obra de Zygmunt Bauman, é inquestionável o fato de que o sociólogo trabalha constantemente questões relacionadas a tais espécies de direitos, refletindo sobre as implicações ideológicas das quais desencadeiam todas as construções que a eles se voltam.

Não significa dizer, porém, que Bauman não se reporte aos Direitos Humanos. Em sua obra, além de tratar assuntos diretamente ligados à discussão dos Direitos Humanos, Bauman tangencia e chega a discutir, algumas vezes, àquele gênero de direitos, embora não dedique - como dito outrora - uma análise específica quanto ao particular.

Assim, analisa a tensão entre segurança e liberdade na comunidade, o caráter conservador do multiculturalismo, o papel do trabalho no contexto liquefeito e a própria concepção de felicidade.

Não se trata, porém, de esgotar toda a discussão sobre Direitos Humanos nos diversos pontos trabalhados por Bauman em toda a sua obra, mas sim de afirmar com base em elementos mínimos o diálogo que estabelece com a filosofia, especificamente no que diz respeito a tal esfera de direitos.

Não se pode ignorar, ademais, o reconhecimento por Bauman da carga valorativa que os Direitos Humanos carregam, no sentido de que representam um verdadeiro "postulado":

Permita-me salientar que, originalmente, como foi articulado na Declaração Universal, o conceito de "direitos humanos" era investido de um significado ainda mais profundo, que até hoje continua a ser um postulado e que em nada impede os Estados dotados de direitos de "abrir exceções" para executar uma lei por meio de sua revogação ou suspensão. Esse significado mais profundo se refere aos direitos humanos

\footnotetext{
${ }^{74}$ Idem. Comunidade: a busca por segurança no mundo atual. Tradução de Plínio Dentzien. Rio de Janeiro: Jorge Zahar, 2003. p. 81.
} 
decorrentes de uma "lei natural" inalienável, que se aplica a todos os homens, incluindo os que foram banidos, despojados de cidadania ou forçados a fugir de seu país por ameaça a suas vidas; aplica-se também aos direitos humanos que substituem as prerrogativas dos governos oriundas da ideia de "soberania": a prerrogativa de negar aos seus próprios cidadãos a dignidade e o respeito devido a todos os homens ${ }^{75}$.

Não obstante o trecho acima, é possível identificar o caráter instrumental dos Direitos Humanos segundo a concepção sociológica de Bauman, posicionamento que permeia a sua obra no que concerne aos assuntos por ele abordados e que estão diretamente relacionados a tais direitos, haja vista que estes são utilizados, segundo sua perspectiva, para manter o status quo, de forma que permanecem inalteradas as desigualdades e a distância do homem da efetiva autoafirmação.

Constata-se, pois, diante da análise da obra de Bauman, que a efetividade dos Direitos Humanos está condicionada proporcionalmente ao grau de solvência dos indivíduos (a possibilidade de "compra" dos direitos humanos), de maneira que tais direitos voltam exclusivamente a uma parcela minoritária, a qual pode vê-los efetivados plenamente.

${ }^{75}$ Idem. Vida a crédito: conversas com Citlali Rovirosa-Madrazo. Tradução de Alexandre Werneck. Rio de Janeiro: Jorge Zahar, 2010. p. 122. 


\title{
5. MODERNIDADE LÍQUIDA, DIREITO DO TRABALHO E O PODER JUDICIÁRIO
}

\begin{abstract}
"O trabalhador brasileiro é um trabalhador rodeado de leis por todos os lados e morto de fome. Tantas leis! Mas falta uma para impedi-lo de morrer de fome". De uma entrevista com um líder sindical dos anos 1950 em Juiz de Fora, Minas Gerais ${ }^{76}$.
\end{abstract}

A afirmação ora transcrita, feita ainda na década de 1950, retrata o latente paradoxo vivenciado pelo trabalhador submetido ao ordenamento jurídico brasileiro.

Inúmeras são as garantias conferidas pelas normas trabalhistas, aliadas aos princípios constitucionais protetores daqueles que desenvolvem um papel fundamental no contexto do processo de produção, sem contudo, terem efetivamente valorizada a atuação.

A transposição da referida afirmação, porém, para o atual contexto, possibilita a visualização do agravamento da realidade no campo do trabalho. Afinal, de lá para cá ampliaram-se significativamente as garantias dos trabalhadores, mas o problema reside na dificuldade de se ver a respectiva efetivação, ou seja, muito se tem no campo hipotético ou no papel, mas pouco se vê na prática.

Não se pode analisar o papel exercido pelo trabalhador, na perspectiva estabelecida pela Carta Cidadã, sob a ótica fria da lei, quando não se vê a materialização do quanto regulamentado.

Com efeito, tais contrastes podem ser apreciados sob a ótica da relação teórica estabelecida na presente pesquisa. A modernidade líquida enfraqueceu o Estado, a política, deslocando o poder para o âmbito do capital, que possui grande força para ditar as regras, ignorando os dispositivos contidos no ordenamento jurídico, o que passa por um futuro processo legitimador da desregulamentação.

\footnotetext{
${ }^{76}$ FRENCH, John D. Afogados em leis: a CLT e a cultura política dos trabalhadores brasileiros. Trad. Paulo Fontes. São Paulo: Editora Fundação Perseu Abramo, 2001. p. 7.
} 
Assim, este último capítulo da pesquisa se debruçará na relação havida entre o Direito do Trabalho e o contexto de modernidade líquida, com os reflexos encontrados na atuação do Poder Judiciário.

No Brasil, os trabalhadores contam com uma justiça especializada para lidar com as questões laborais, instituição que abrange desde as Varas do Trabalho, onde, via de regra, se origina a jurisdição, passando pelos Tribunais Regionais do Trabalho (TRT) e terminando com o Tribunal Superior do Trabalho (TST), em Brasília.

Especializar um ramo do Poder Judiciário, disponibilizando-lhe uma estrutura específica para cuidar de situações peculiares, representa uma grande e importante conquista no que diz respeito ao Direito do Trabalho. Afinal, as questões trabalhistas demandam uma sensibilidade ímpar para serem julgadas, são norteadas por princípios distintos do Direito Comum e cuidam de relações peculiares, uma vez que havidas entre particulares, mas subordinadas constantemente à regulamentação estatal, de maneira que há forte necessidade de se ver o Estado presente. É exatamente neste ponto que surge uma dúvida: ora, considerando-se o caminho da presente investigação, tem-se que o Estado se enfraqueceu na modernidade líquida, uma vez que o poder não está mais sob a sua titularidade, de maneira que o primeiro questionamento a ser feito, na sequência do raciocínio, reside na possibilidade de a Justiça do Trabalho ser autora da plena efetivação do Direito do Trabalho e, em caso positivo, estabelecer quais seriam os limites encontrados no âmbito da sua atuação.

Para tanto, será considerada a atuação da Justiça do Trabalho a partir de dois principais pontos, quais sejam, a jurisprudência e a forte política de conciliação encampada nos últimos tempos.

\subsection{JURISPRUDÊNCIA}

Para percorrer o campo da jurisprudência trabalhista, é importante considerar o órgão que exerce fundamentalmente o papel de uniformizá-la: o Tribunal Superior do Trabalho. Órgão de cúpula da Justiça do Trabalho, conforme preconiza o art. 
111, I, da Constituição Federal, o referido Tribunal possui, como principal missão, a uniformização da jurisprudência trabalhista.

Com efeito, para cumprir tal função, o Tribunal Superior do Trabalho se vale, como principais instrumentos, das $\operatorname{súmulas}^{77}$, dos precedentes normativos e das orientações jurisprudenciais ${ }^{78}$.

Serão analisadas, na presente pesquisa, algumas orientações jurisprudenciais e súmulas, com o intuito de demonstrar a necessidade de se interpretar o Direito do Trabalho sob a égide dos Direitos Humanos.

\subsubsection{RENÚNCIA NAS NEGOCIAÇÕES COLETIVAS - O CASO DOS TURNOS ININTERRUPTOS DE REVEZAMENTO}

A questão atinente aos turnos ininterruptos de revezamento guarda relação com um posicionamento jurisprudencial que tem preponderado no âmbito do Tribunal Superior do Trabalho.

Cumpre esclarecer, inicialmente, o que vem a ser turno ininterrupto de revezamento. Segundo Ives Gandra da Silva Martins Filho:

\footnotetext{
77 As súmulas estão previstas nos arts. 159-166, do Regimento Interno do Tribunal Superior do Trabalho, sendo que a edição, revisão ou cancelamento delas ficará a cargo do Tribunal Pleno, conforme disposto pelo art. 68, VII, do mencionado Regimento. As súmulas correspondem a enunciados que delimitam determinados entendimentos consolidados e uniformes exarados pela Corte Trabalhista, constituindo uma ferramenta para agilizar a jurisdição, inclusive no que diz respeito ao acesso ao TST, uma vez que o art. 896 da CLT considera a decisão contrária a qualquer súmula vigente do referido tribunal como uma das hipóteses contempladas para o conhecimento do recurso de revista. Este último representa a medida processual utilizada para reformar decisões prolatadas pelos Tribunais Regionais do Trabalho dissonantes com a jurisprudência predominante na Corte Trabalhista.

${ }_{78}$ Os precedentes normativos e as orientações jurisprudenciais constam dos arts. 167-173, do Regimento Interno do Tribunal Superior do Trabalho, enunciando a jurisprudência prevalente nas subseções (Subseção de Dissídios Individuais - 1, Subseção de Dissídios Individuais - 2), Seção de Dissídios Coletivos (SDC) e Tribunal Pleno. A diferença destes para as súmulas consiste, basicamente, no fato de que as últimas possuem caráter mais definitivo, pois são deliberadas pelo Tribunal Pleno, constituído por todos os ministros integrantes do TST, enquanto os primeiros não possuem o forte caráter de consolidação marcante nas súmulas, além do fato de que os requisitos (ou pressupostos, termo utilizado pelo Regimento Interno do TST, nos arts. 165, 168 e 170-171) para a aprovação deles são menos rigorosos.
} 
Trata-se de trabalho em atividade produtiva contínua da empresa, que supõe revezamento de equipes de empregados, dos quais não pode ser exigida jornada ininterrupta superior a 6 horas, salvo negociação coletiva. Supõe alternância de jornada diurna e noturna, provocando maior desgaste físico do empregado, pela contínua variação de seus ciclos biológicos ${ }^{79}$.

Os turnos ininterruptos de revezamento propiciaram um intenso debate doutrinário e jurisprudencial, com o advento da Constituição Federal de 1988, uma vez que tal diploma dispõe, no art. $7^{\circ}$, XIV, que "são direitos dos trabalhadores urbanos e rurais, além de outros que visem à melhoria de sua condição social: (...) jornada de seis horas para o trabalho realizado em turnos ininterruptos de revezamento, salvo negociação coletiva".

Assim, mediante o referido inciso, a carta constitucional possibilitou a denominada flexibilização da jornada de trabalho no âmbito dos turnos ininterruptos de revezamento, condicionando-a à previsão em sede de negociação coletiva.

O debate apenas aumentou, permeando desde a discussão acerca do intervalo para refeição e descanso quando o trabalhador exerce suas funções dentro de tais jornadas até o questionamento se deveria o empregador remunerar o empregado que se ativou após a sexta hora diária em turnos ininterruptos de revezamento, tendo culminado com a edição da Súmula 423 do TST, a qual definiu a situação, determinando que "estabelecida jornada superior a seis horas e limitada a oito horas por meio de regular negociação coletiva, os empregados submetidos a turnos ininterruptos de revezamento não têm direito ao pagamento da $7^{\mathrm{a}}$ e $8^{\mathrm{a}}$ horas como extras".

Porém, a situação não se encontra resolvida, esbarrando na problemática da negociação coletiva.

A Carta Cidadã assegurou, por meio do art. $7^{\circ}$, XXVI, o "reconhecimento das convenções e acordos coletivos de trabalho" ${ }^{\circ 0}$, instrumentos pelos quais são materializadas as negociações coletivas.

\footnotetext{
${ }^{79}$ MARTINS FILHO, Ives Gandra da Silva. Manual de Direito e Processo do Trabalho. 18.ed. São Paulo: Saraiva, 2009. p. 143.

${ }^{80}$ Cumpre esclarecer a diferença entre convenção e acordo coletivo de trabalho, uma vez que aquela representa a negociação coletiva entre sindicatos de empregadores e de trabalhadores, enquanto esta resulta da negociação entre o empregador e o sindicato de trabalhadores.
} 
Assim, considerada a participação dos sindicatos de trabalhadores nas negociações coletivas, o Tribunal Superior do Trabalho houve por bem interpretar os ditames constitucionais de maneira a excluir o empregador do pagamento das horas excedentes à sexta diária, nas condições ora estudadas.

Esqueceu-se, porém, que a possibilidade conferida pelo primeiro dispositivo constitucional mencionado passou a ser objeto de verdadeira renúncia pelos trabalhadores.

$\mathrm{Na}$ realidade, o termo negociação, escrito com propósito pelo constituinte, remete ao sentido de concessões recíprocas, o que significa dizer, empregado e empregador, na elaboração de uma norma coletiva, irão ajustar seus interesses de maneira que ambos possam ceder e receber benefícios. Assim seria uma negociação regular, praticada nos termos da Constituição Federal. Caso contrário, o termo seria qualquer outro que não o da negociação.

Não obstante, na prática passou-se a verificar a existência de verdadeiras renúncias ao direito à jornada reduzida, pelos empregados submetidos aos turnos ininterruptos de revezamento, de maneira que as "negociações coletivas" (que em nada configuram negociações) foram utilizadas para majorar as jornadas em tal sistema, sem, contudo, contemplar os empregados com qualquer benefício em troca.

E o Tribunal Superior do Trabalho, ao uniformizar a jurisprudência, tem ignorado a existência de tais renúncias, conforme se verifica no trecho abaixo (íntegra disponível no anexo I):

(...)Verifica-se que, ao contrário do que sustenta o reclamante, o entendimento firmado no acórdão recorrido sobre elastecimento da jornada mediante acordo é válido, mesmo sem a pactuação de qualquer contraprestação pecuniária em favor dos empregados, uma vez que o artigo $7^{\circ}$, inciso XIV, da Constituição Federal não condiciona a validade do elastecimento a nenhuma contraprestação ${ }^{81}$.

${ }^{81}$ BRASIL. Tribunal Superior do Trabalho. RR - 294-59.2010.5.03.0142, Relator Ministro: José Roberto

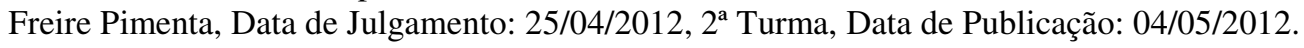


A ementa a seguir aponta para o mesmo sentido (íntegra disponível no

anexo II):

TURNO ININTERRUPTO DE REVEZAMENTO. HORAS EXTRAS. ELASTECIMENTO DA JORNADA POR ACORDO COLETIVO. VALIDADE. Nos termos da Súmula $n^{\circ} 423$ desta Corte, -estabelecida jornada superior a seis horas e limitada a oito horas por meio de regular negociação coletiva, os empregados submetidos a turnos ininterruptos de revezamento não têm direito ao pagamento da $7^{\mathrm{a}}$ e $8^{\mathrm{a}}$ horas como extra-. E, de acordo com o entendimento da SBDI-1 desta Corte, é válido o acordo coletivo que elastece a jornada de trabalho dos empregados sujeitos ao regime de turnos ininterruptos de revezamentos, mesmo sem a pactuação de qualquer contraprestação em favor dos trabalhadores. Recurso de revista conhecido e provido. CORREÇÃO MONETÁRIA. ÉPOCA PRÓPRIA. SÚMULA No 381 DO TST. Nos termos da Súmula $\mathrm{n}^{\circ} 381$ do TST, -o pagamento dos salários até o $5^{\circ}$ dia útil do mês subsequente ao vencido não está sujeito à correção monetária. Se essa data limite for ultrapassada, incidirá o índice da correção monetária do mês subsequente ao da prestação dos serviços, a partir do dia $1^{\circ}{ }^{-}$. Recurso de revista conhecido e provido ${ }^{82}$.

Assim, as decisões acima transcritas representam uma mera amostra que reflete o sentido do entendimento jurisprudencial oriundo do Tribunal Superior do Trabalho.

Não se pode ignorar, contudo, a participação dos sindicatos de trabalhadores junto às negociações coletivas. Porém, também é inquestionável o enfraquecimento dos órgãos de representação de classe nos últimos tempos, especialmente quando colocados diante de verdadeiras potências econômicas.

Ao Poder Judiciário é possível, indubitavelmente, invalidar as normas que constituem verdadeira renúncia aos direitos mínimos dos trabalhadores, uma vez que este é o espírito da lei, expresso pelo caput do art. $7^{\circ}$ da Constituição Federal ${ }^{83}$, no sentido de que os direitos dos trabalhadores devem pautar-se pela melhoria de sua condição social. $\mathrm{Na}$ situação em apreço, verifica-se um verdadeiro retrocesso, que traz prejuízo aos

\footnotetext{
${ }^{82}$ BRASIL. Tribunal Superior do Trabalho. RR - 116100-55.2003.5.05.0491, Relator Ministro: José Roberto Freire Pimenta, Data de Julgamento: 25/04/2012, $2^{\mathrm{a}}$ Turma, Data de Publicação: 04/05/2012.

${ }^{83}$ São direitos dos trabalhadores urbanos e rurais, além de outros que visem à melhoria de sua condição social.
} 
empregados sob a ratificação do Poder Judiciário, ou seja, absolutamente legítimo aos olhos da lei.

\subsubsection{OS TRABALHADORES RURAIS}

Os trabalhadores rurais compõem uma parcela ainda desprovida da proteção necessária às tão peculiares condições de trabalho em que se ativam.

Considerando-se que o presente trabalho não se limita exclusivamente ao estudo dos referidos trabalhadores, dada a vasta possibilidade de se analisar tal categoria, não se pretende esgotar todas as questões que os oprimem e prejudicam no contexto laboral. Entretanto, é importante resgatar a realidade peculiar dos trabalhadores rurais ao debruçar-se sobre a problemática do Direito do Trabalho sob a ótica da presente pesquisa.

Assim, relativamente a tal grupo, serão analisados dois pontos existentes e oportunos no contexto jurisprudencial: a remuneração pela ativação em jornada extraordinária e a sujeição às condições de trabalho degradantes.

Primeiramente, sabe-se que é comum, na prática salarial dos trabalhadores rurais, remunerá-los por produção. Tal política prejudica os trabalhadores, de maneira que são incentivados a exercer um esforço enorme para melhorar a baixa remuneração praticada pelos empregadores. Porém, diante das poucas opções para manter a sobrevivência, acabam por se sujeitar à referida situação.

Neste sentido, o Tribunal Superior do Trabalho, por meio da Seção de Dissídios Individuais - 1 (SDI-1), editou a Orientação Jurisprudencial 235, cujos termos determinavam no sentido de que "o empregado que recebe salário por produção e trabalha em sobrejornada faz jus à percepção apenas do adicional de horas extras”.

Desta forma, entendia a Corte Trabalhista que a jornada extraordinária já estaria paga de forma simples, pelo que remanescia apenas o adicional a ela referente ${ }^{84}$.

84 RECURSO DE REVISTA. PRESCRIÇÃO. TRABALHADOR RURAL. AÇÃO AJUIZADA POSTERIORMENTE À EMENDA CONSTITUCIONAL 28/2000. Ajuizada a ação dentro do prazo de cinco 
Não se considerou, porém, a situação perversa que tal posicionamento propiciaria, uma vez que seria mais uma forma de se conceder aos empregadores uma maximização de seus lucros por meio da remuneração mencionada.

Ora, a situação vivenciada pelos trabalhadores rurais no Brasil guarda uma história de intensa exploração, marcada fortemente por péssimas condições de trabalho, jornadas excessivas, num ambiente marcado pela insalubridade e degradante da dignidade humana.

A discussão doutrinária e jurisprudencial, entretanto, seguiu cada vez maior, uma vez que passou a ser questionada a situação peculiar vivenciada pelos trabalhadores rurais, permitindo a evolução da jurisprudência nesse sentido ${ }^{85}$, de maneira

anos contados da vigência da Emenda Constitucional no 28/2000 e de dois anos contados da extinção do contrato, tem o empregado garantida a imprescritibilidade dos direitos oriundos do vínculo de emprego. Exegese do novo teor da Orientação Jurisprudencial no 271 da SDI-1. Recurso de revista não conhecido. INTERVALO INTRAJORNADA. ARTIGO 71, $\S 4^{\circ}$, DA CLT. TRABALHADOR RURAL. APLICABILIDADE. A legislação que regulamenta o trabalho rural estabelece a obrigatoriedade da concessão de intervalo intrajornada de, no mínimo, uma hora para o trabalho contínuo superior a seis horas, observados os usos e costumes da região (art. $5^{\circ}$, Decreto 73.626/74). Caso em que, não observado o intervalo ajustado, ou mesmo qualquer outro, decorrente de um costume usual da região, conforme estabelece a lei que ampara o trabalhador rural, há que ser considerada a aplicação do disposto no $\S 4^{\circ}$ do artigo 71 da CLT, considerando-se a harmonia entre as normas e a equiparação dos trabalhadores urbanos e rurais, determinada no artigo $7^{\circ}$ da Constituição Federal. Recurso de revista não conhecido. ADICIONAL DE HORAS EXTRAORDINÁRIAS. SALÁRIO POR PRODUÇÃO. A atual redação da Orientação Jurisprudencial $n^{\circ} 235$ da SBDI-1 do C. TST consagra o entendimento de que o empregado que recebe salário por produção e trabalha em regime de sobrejornada faz jus à percepção apenas do adicional das horas excedentes ao limite diário e semanal. Recurso de revista conhecido e provido. In BRASIL. Tribunal Superior do Trabalho. RR - 15000-41.2005.5.15.0125, Relator Ministro: Aloysio Corrêa da Veiga, Data de Julgamento: 04/11/2009, 6 ${ }^{a}$ Turma, Data de Publicação: 13/11/2009.

${ }^{85}$ RECURSO DE REVISTA. 1. TRABALHADOR BRAÇAL RURAL. HORAS EXTRAS. PAGAMENTO INTEGRAL DO TEMPO DE LABOR EM SOBREJORNADA, ACRESCIDO DO ADICIONAL. Esta Corte tem reiteradamente decidido que a Orientação Jurisprudencial no 235 da SDI-1 não alcança os trabalhadores da lavoura de cana-de-açúcar, em razão das condições específicas a que estão submetidos no desempenho de suas atividades. Precedentes. Recurso de revista não conhecido. 2. DANO MORAL. TRABALHO RURAL. INSTALAÇÕES SANITÁRIAS E PARA REFEIÇÕES INADEQUADAS. NORMA REGULAMENTADORA No 31 DO MTE. INOBSERVÂNCIA. O descaso com a adequada oferta de instalações sanitárias e para refeições, aos trabalhadores rurais, segundo as normas de regência próprias, autoriza concluir-se pela configuração de dano moral. Ofensa ao princípio da dignidade humana, inscrito no art. $1^{\circ}$, III, da Constituição Federal. Recurso de revista não conhecido. 3. INDENIZAÇÃO POR DANO MORAL. PARÂMETROS RELEVANTES PARA AFERIÇÃO DO VALOR DA INDENIZAÇÃO. SISTEMA ABERTO. DOSIMETRIA DO -QUANTUM- INDENIZATÓRIO. 3.1. Dano moral consiste em lesão a atributos íntimos da pessoa, de modo a atingir valores juridicamente tutelados, cuja mensuração econômica envolve critérios objetivos e subjetivos. 3.2. A indenização por dano moral revela conteúdo de interesse público, na medida em que encontra ressonância no princípio da dignidade da pessoa humana, sob a perspectiva de uma sociedade que se pretende livre, justa e solidária (CF, arts. $1^{\circ}$, III, e $3^{\circ}$, I). 3.3. A dosimetria do -quantum- indenizatório guarda relação direta com a existência e a extensão do dano sofrido, o grau de culpa e a perspectiva econômica do autor e da vítima, razão pela qual a atuação dolosa do agente reclama reparação econômica mais severa, ao passo que a imprudência ou negligência clamam por reprimenda mais branda. 3.4. Assim, à luz do sistema aberto, cabe ao julgador, atento aos parâmetros relevantes para aferição do valor da indenização por dano moral, fixar o -quantum- indenizatório com prudência, bom senso e razoabilidade, sob pena de afronta ao princípio da restauração justa e proporcional. 
que o Tribunal Superior do Trabalho reformulou o teor da Orientação Jurisprudencial 235 da SDI-1, nos seguintes termos: "o empregado que recebe salário por produção e trabalha em sobrejornada tem direito à percepção apenas do adicional de horas extras, exceto no caso do empregado cortador de cana, a quem é devido o pagamento das horas extras e do adicional respectivo".

O fato de a Corte Trabalhista ter excepcionado a restrição ao pagamento da hora extra acrescida do adicional, relativamente ao empregado cortador de cana, representou um avanço.

Porém, tal o fora insuficiente, uma vez que não é apenas o cortador de cana que se submete a condições difíceis de trabalho no campo, mas também outros trabalhadores rurais.

Imprescindível destacar, ainda, que a Constituição Federal determina, nos termos do art. $7^{\circ}, \mathrm{XVI}$, a "remuneração do serviço extraordinário superior, no mínimo, em cinquenta por cento à do normal”, sem excepcionar qualquer situação. Rurais, urbanos, remunerados por produção, os trabalhadores estão classificados de várias formas na legislação, mas a classificação não pode chegar ao limite de prejudicá-los, sob pena de a norma nortear para o vazio.

O segundo ponto a ser tratado, não obstante a questão acima exposta, diz respeito às condições degradantes de trabalho a que os trabalhadores rurais são submetidos e à resposta dada pela jurisprudência diante de toda a problemática atinente a tal questão.

O Ministério do Trabalho e Emprego, no ano de 2005, editou a Norma Regulamentadora $^{86} 31$, dispondo sobre segurança e saúde no trabalho na agricultura,

Recurso de revista não conhecido. In BRASIL. Tribunal Superior do Trabalho. RR - 847-52.2010.5.15.0052, Relator Ministro: Alberto Luiz Bresciani de Fontan Pereira, Data de Julgamento: 14/12/2011, $3^{\mathrm{a}}$ Turma, Data de Publicação: 19/12/2011.

${ }^{86}$ Relativamente às normas regulamentadoras, é importante destacar o teor do art. 155 da CLT, segundo o qual: “ Incumbe ao órgão de âmbito nacional competente em matéria de segurança e medicina do trabalho: I estabelecer, nos limites de sua competência, normas sobre a aplicação dos preceitos deste Capítulo, especialmente os referidos no art. 200; II - coordenar, orientar, controlar e supervisionar a fiscalização e as demais atividades relacionadas com a segurança e a medicina do trabalho em todo o território nacional, inclusive a Campanha Nacional de Prevenção de Acidentes do Trabalho; III - conhecer, em última instância, dos recursos, voluntários ou de ofício, das decisões proferidas pelos Delegados Regionais do Trabalho, em matéria de segurança e medicina do trabalho". 
pecuária, silvicultura, exploração florestal e aquicultura e, tal norma, dentre várias questões abordadas, dispõe que:

31.23.1 O empregador rural ou equiparado deve disponibilizar aos trabalhadores áreas de vivência compostas de: a) instalações sanitárias; b) locais para refeição; c) alojamentos, quando houver permanência de trabalhadores no estabelecimento nos períodos entre as jornadas de trabalho; d) local adequado para preparo de alimentos; e) lavanderias ${ }^{87}$.

A referida norma, nos itens seguintes, determina as condições mínimas a serem observadas pelo empregador rural ou equiparado, de maneira a possibilitar um ambiente de trabalho adequado aos trabalhadores ${ }^{88}$.

O problema relativo às questões ora colocadas existe há muito tempo. Com o advento da citada norma regulamentadora, passou-se a questionar, perante o Poder Judiciário, o seu descumprimento por parte dos empregadores, especialmente no sentido de que a mencionada inobservância constitui ato ilícito, passível de indenização por dano moral.

A Norma Regulamentadora 31 não dispôs nada diferente ou contrário ao espírito da Constituição Federal e da legislação trabalhista como um todo, uma vez que não é preciso grande esforço para verificar se determinadas condições de trabalho são degradantes ou não, quando se fala de questões tão básicas como instalações sanitárias, locais para refeição, entre outras.

As duas ementas a seguir, referentes à questão ora analisada, representam uma interpretação que vem sendo encontrada no âmbito jurisprudencial (as decisões se encontram, na íntegra, respectivamente nos anexos III e IV):

\footnotetext{
${ }^{87}$ BRASIL. Ministério do Trabalho e Emprego. NR-31 Segurança e Saúde no Trabalho na Agricultura, Pecuária, Silvicultura, Exploração Florestal e Aquicultura. Disponível em: $<$ http://portal.mte.gov.br/data/files/8A7C812D33EF459C0134561C307E1E94/NR-

31\%20(atualizada\%202011).pdf>. Acesso em 14.mai.2012.

${ }^{88}$ No item 31.23.4.1, por exemplo, a NR-31 do MTE, ao dispor sobre os locais para refeição, prevê que eles devem "atender aos seguintes requisitos: a) boas condições de higiene e conforto; b) capacidade para atender a todos os trabalhadores; c) água limpa para higienização; d) mesas com tampos lisos e laváveis; e) assentos em número suficiente; f) água potável, em condições higiênicas; g) depósitos de lixo, com tampas”.
} 
Processo: RO-02219.2008.051.23.00-6 Relator: DESEMBARGADOR ROBERTO BENATAR, Revisor: JUIZ CONVOCADO AGUIMAR PEIXOTO, Órgão Judicante: $1^{\mathrm{a}}$ Turma, Data de Julgamento: 27/04/2010, Data de Publicação: 05/05/2010, Ementa: DANO MORAL. TRABALHO EM CONDIÇÕES DEGRADANTES. O direito à indenização por dano moral pressupõe a comprovação da conduta culposa do empregador, do dano ao empregado e do nexo causal entre o ato do empregador e o prejuízo sofrido. O caso dos autos é afeto, em tese, à hipótese que repetidas vezes tem se apresentado aos pretórios trabalhistas, qual seja, exposição do trabalhador à situação degradante durante a prestação de serviços, a qual, compete registrar, é hábil em tese à caracterização de danos aos direitos da personalidade. Na hipótese, constataram-se duas irregularidades em confronto com a NR-31, quais sejam, os sanitários, embora limpos e em locais de difícil acesso, não eram separados por sexo, bem assim que não havia local adequado para se fazer as refeições, as quais não são graves o suficiente a configurar a existência de trabalho degradante, tratando-se de meras irregularidades, não sendo hábeis a provocar danos na dignidade do ser humano ${ }^{89}$.

TRABALHO RURAL. PRECARIEDADE DAS INSTALAÇÕES SANITÁRIAS E REFEITÓRIOS. INEXISTÊNCIA DE DANOS MORAIS INDENIZÁVEIS. Diante das condições rústicas inerentes ao ambiente de trabalho rural, bem como da notória dificuldade do empregador de proporcionar instalações sanitárias satisfatórias e refeitórios adequados, não emerge dano moral indenizável, em que pesem os dissabores e desconfortos sofridos pelos trabalhadores ${ }^{90}$.

Reconhecer a realidade dos trabalhadores rurais constitui um ponto necessário e do qual não há como esquivar-se. Porém, admitir que tal situação se prolongue na história, mesmo diante de todo o arcabouço legal existente, capaz de fundamentar uma atuação contrária à degradação da dignidade humana, representa uma confirmação de que são necessárias mudanças.

O Poder Judiciário não pode atuar como um ente destinado a homologar a exploração dos trabalhadores. É preciso que a Justiça do Trabalho seja revista e ostensiva no discurso dos direitos sociais, confirmando as garantias que, para serem conquistadas, necessitaram passar por intensos processos históricos permeados por luta e opressão.

${ }^{89}$ BRASIL. Tribunal Regional do Trabalho da $23^{a}$ Região. Diário Eletrônico da Justiça do Trabalho. n. 472/2010, 5 mai. 2010.

90 BRASIL. Tribunal Regional do Trabalho da $15^{\text {a }}$ Região. Disponível em: $<$ http://www.trt15.jus.br/consulta/owa/documento.pdf?pAplicacao=DOCASSDIG\&pid=4702037>. Acesso em 14.05.2012. 
Quanto ao particular, portanto, é possível estabelecer uma aplicação do direito reconhecendo a dignidade dos empregados. Afinal, o norte da justiça distributiva aponta para a essência compensatória da lógica dos direitos sociais, a qual merece ser respeitada por todos aqueles que trabalham com as questões postas em análise.

\subsubsection{O INTERVALO PARA REFEIÇÃO E DESCANSO}

A questão da saúde no ambiente de trabalho é bastante recorrente nos dias atuais, sendo que o intervalo intrajornada integra uma das vias eleitas pelo ordenamento jurídico para, além de garantir condições dignas de trabalho, atingir a finalidade de manter a saúde e a qualidade de vida do trabalhador.

Estabelece o art. 71 do diploma consolidado:

Em qualquer trabalho contínuo, cuja duração exceda de seis horas, é obrigatória a concessão de um intervalo para repouso ou alimentação, o qual será, no mínimo, de uma hora e, salvo acordo escrito ou contrato coletivo em contrário, não poderá exceder de duas horas.

$[\ldots]$

$\S 2^{\circ}$ Os intervalos de descanso não serão computados na duração do trabalho.

$[\ldots]$

$\S 4^{\circ}$ Quando o intervalo para repouso e alimentação, previsto neste artigo, não for concedido pelo empregador, este ficará obrigado a remunerar o período correspondente com um acréscimo de no mínimo cinquenta por cento sobre o valor da remuneração da hora normal de trabalho.

Segundo a dicção do $\S 2^{\circ}$. do dispositivo legal acima transcrito, a pausa intervalar não é computada na duração do trabalho, variando conforme a jornada contratual, exceto quando o intervalo concedido exceder os limites acima expostos. Dispõe a Súmula 118 do Tribunal Superior do Trabalho, in verbis: 
Os intervalos concedidos pelo empregador na jornada de trabalho, não previstos em lei, representam tempo à disposição da empresa, remunerados como serviço extraordinário, se acrescidos ao final da jornada.

Não obstante a referida previsão legal, o intervalo intrajornada constitui um dos direitos mais violados pelos empregadores que, em desrespeito aos trabalhadores, acabam por deteriorar as próprias relações constituídas. O instituto em estudo constitui direito indisponível, haja vista a sobreposição do interesse público em detrimento do privado, sendo que neste último os contratantes possuem ampla liberdade na realização de negócios jurídicos. Dispõe o $§ 3^{\circ}$ do artigo 71 da CLT:

O limite mínimo de uma hora para repouso ou refeição poderá ser reduzido por ato do Ministério do Trabalho, quando, ouvido o Departamento Nacional de Higiene e Segurança do Trabalho (DINHST) (atualmente Secretaria de Segurança e Medicina do Trabalho - SSMT), se verificar que o estabelecimento atende integralmente às exigências concernentes à organização dos refeitórios e quando os respectivos empregados não estiverem sob regime de trabalho prorrogado a horas suplementares.

Assim, à redução do intervalo intrajornada se faz imprescindível a coexistência do quanto exigido pelo dispositivo legal em questão.

Partindo-se do âmbito legislativo para os entendimentos dele decorrentes, é possível destacar alguns pontos principais, dos quais serão analisadas três orientações jurisprudenciais editadas pelo Tribunal Superior do Trabalho e os reflexos na jurisprudência dos demais tribunais.

Prosseguindo-se na investigação sobre a redução da pausa intervalar, cumpre registrar a edição da Orientação Jurisprudencial 342 da SDI-1 do Tribunal Superior do Trabalho:

I - É inválida cláusula de acordo ou convenção coletiva de trabalho contemplando a supressão ou redução do intervalo intrajornada porque este constitui medida de higiene, saúde e segurança do trabalho, garantido 
por norma de ordem pública (art. 71 da CLT e art. $7^{\circ}, \mathrm{XXII}$, da CF/88), infenso à negociação coletiva.

II - Ante a natureza do serviço e em virtude das condições especiais de trabalho a que são submetidos estritamente os condutores e colaboradores de veículos rodoviários, empregados em empresas de transporte público coletivo urbano, é válida cláusula de acordo ou convenção coletiva de trabalho contemplando a redução do intervalo, desde que garantida a redução da jornada para, no mínimo, sete horas diárias ou quarenta e duas semanais, não prorrogada, mantida a mesma remuneração e concedidos intervalos para descanso menores e fracionários ao final de cada viagem, não descontados da jornada.

O primeiro inciso da referida orientação jurisprudencial guarda total consonância com as normas trabalhistas vigentes no país. Já o segundo excepciona a previsão legal no que diz respeito aos condutores e colaboradores de veículos rodoviários, o que merece ser ressalvado, uma vez que a legislação não exclui nenhuma categoria dos seus ditames.

Não obstante, verifica-se que o agente do direito atuante na seara trabalhista, quando diante da inobservância do intervalo intrajornada, vê-se diante de um dilema interpretativo no sentido dos efeitos que a concessão parcial do referido intervalo gerará.

$\mathrm{O} \S 4^{\circ}$ do art. 71 da CLT dispõe expressamente acerca da não concessão do intervalo intrajornada, que importará na remuneração do período correspondente com o acréscimo ali disposto. Se lido em conformidade com os princípios norteadores do Direito do Trabalho, o referido parágrafo é suficiente para esclarecer as consequências do desrespeito ao intervalo intrajornada.

Porém, os reflexos da inobservância do art. 71 da CLT foram objeto de grande discussão interpretativa. Tal discussão ganhou tamanha dimensão que, na busca de editar instrumento jurisprudencial que norteasse seu posicionamento, a $1^{\mathrm{a}}$. Seção de Dissídios Individuais do Tribunal Superior do Trabalho editou a Orientação Jurisprudencial 307, segundo a qual:

Após a edição da Lei 8923/94, a não concessão total ou parcial do intervalo intrajornada mínimo, para repouso e alimentação, implica o pagamento total do período correspondente, com acréscimo de, no 
mínimo, $50 \%$ sobre o valor da remuneração da hora normal de trabalho (art. 71 da CLT).

Considerando-se o teor da referida Orientação Jurisprudencial, deixará o empregador de observar o intervalo intrajornada caso não conceda o período previsto em lei, bem como diante da concessão parcial deste. Não obstante, ainda que o empregador observe o período legal, fracionando a pausa, também deixará de observar o referido instituto e deverá arcar com as mesmas consequências.

Todavia, diante da literalidade da Orientação Jurisprudencial 307, estabeleceu-se grande dissenso jurisprudencial, já que duas interpretações básicas decorrem da dicção daquela: a primeira afirma que a violação do intervalo intrajornada acarreta o pagamento do período total previsto, além do acréscimo à razão de cinquenta por cento; a segunda interpretação, por sua vez, informa que apenas o período não concedido deverá ser pago, deduzida a pausa concedida do intervalo obrigatório, com o respectivo acréscimo legal.

Mais uma vez seria possível solucionar a questão, se consideradas a tutela conferida ao intervalo intrajornada e a importância dispensada a este pelo legislador, além dos princípios que informam o Direito do Trabalho e norteiam, assim, a atividade interpretativa dos agentes do direito.

Ademais, para aqueles que buscam na literalidade da lei a resposta aos dilemas interpretativos, a própria CLT oferece subsídios para solucionar tal conflito. Afinal, considerando-se que a violação do intervalo intrajornada prejudica completamente os objetivos deste instituto, é possível recorrer à incidência do art. $9^{\circ}$ do referido diploma legal, segundo o qual:

Serão nulos de pleno direito os atos praticados com o objetivo de desvirtuar, impedir ou fraudar a aplicação dos preceitos contidos na presente Consolidação. 
Logo, ao impedir a aplicação do instituto previsto no art. 71 da referida lei, deverá ser considerada nula a concessão que deixa de observar o tempo nela previsto, razão pela qual deverá ser paga a hora integral, nos termos do $\S 4^{\circ}$.

Cumpre destacar, ainda, a edição da Orientação Jurisprudencial 381 da $1^{\text {a }}$ Seção de Dissídios Individuais do TST, cujo teor dispõe:

\begin{abstract}
A não concessão total ou parcial do intervalo mínimo intrajornada de uma hora ao trabalhador rural, fixado no Decreto . $^{\circ} 73.626$, de 12.02.1974, que regulamentou a Lei . $^{\circ} 5.889$, de 08.06.1973, acarreta o pagamento do período total, acrescido do respectivo adicional, por aplicação subsidiária do art. $71, \S 4^{\circ}$, da CLT.
\end{abstract}

Assim, se o fundamento da referida orientação, ao determinar o pagamento do período total do intervalo intrajornada, ainda que em face de sua concessão parcial, é o $\S 4^{\circ}$ do art. 71 da CLT, não restaria razão alguma para que subsistisse o mencionado dilema interpretativo. E, embora seja relativa ao trabalhador rural, tal Orientação Jurisprudencial se baseia no art. $71, \S 4^{\circ}$ da CLT, sendo perfeitamente aplicável por analogia aos demais trabalhadores.

Com efeito, pode-se questionar a importância de se refletir sobre a discussão em destaque, uma vez que o intervalo intrajornada é um mero detalhe no âmbito das relações laborais.

Porém, o conflito gerado é importante para demonstrar o diagnóstico do enfraquecimento da regulamentação assegurada aos trabalhadores pelo ordenamento jurídico. Travou-se grande discussão sobre um instituto que está regulamentado por dispositivo legal próprio, o que ocorre por influência do contexto em que se insere o processo de concessão de garantias aos trabalhadores.

A CLT fornece dispositivos hábeis à solução de eventuais questionamentos, mas foi necessário chegar até o Poder Judiciário para dirimir sobre o conflito jurisprudencial surgido em torno do intervalo intrajornada.

$\mathrm{Na}$ verdade, ao interpretar as mencionadas garantias de maneira restrita, mitigando as garantias previstas no ordenamento jurídico, o Poder Judiciário confirma o 
processo fluido cada vez mais intensificado na sociedade, inclusive no âmbito das relações laborais, fortes contribuintes do funcionamento da estrutura social.

\subsection{CONCILIAR É "LEGAL"?}

Sabe-se que a conciliação permeia as diretrizes normativas há algum tempo e, a partir da Constituição Federal de 1988, o ordenamento jurídico passou a contar com determinados dispositivos legais, como o art. $2^{\circ}$ da Lei 9.099/95 (Juizados Especiais Cíveis e Criminais) ${ }^{91}$, bem assim o art. $3^{\circ}$ da Lei 10.259/2001 (Juizados Especiais Federais $)^{92}$, voltados à conciliação.

No âmbito trabalhista, as atualmente denominadas Varas do Trabalho foram chamadas de Juntas de Conciliação e Julgamento até o advento da Emenda Constitucional 24, de 1999, que também excluiu dos quadros da Justiça do Trabalho a figura do juiz classista. A vocação conciliatória, porém, não deixou de ser praticada com a mera alteração da denominação.

$\mathrm{Na}$ própria CLT, encontram-se vários dispositivos voltados à conciliação, a começar pela previsão das Comissões de Conciliação Prévia (art. 625- $\mathrm{A}^{93}$ ), merecendo destaque o art. 764, segundo o qual "os dissídios individuais ou coletivos submetidos à apreciação da Justiça do Trabalho serão sempre sujeitos à conciliação". Este artigo prevê, ainda, em seu $\S 1^{\circ}$, que "os juízes e Tribunais do Trabalho empregarão sempre os seus bons ofícios e persuasão no sentido de uma solução conciliatória dos conflitos".

É inquestionável a característica eminentemente conciliatória da Justiça do Trabalho, advinda de expressa previsão legal pelo diploma consolidado. O problema é colocá-la em consonância com o texto constitucional e a perspectiva dos direitos humanos.

\footnotetext{
91 "Art. $2^{\circ} \mathrm{O}$ processo orientar-se-á pelos critérios da oralidade, simplicidade, informalidade, economia processual e celeridade, buscando, sempre que possível, a conciliação ou a transação".

92 “Art. 3ํㅡㄹ Compete ao Juizado Especial Federal Cível processar, conciliar e julgar causas de competência da Justiça Federal até o valor de sessenta salários mínimos, bem como executar as suas sentenças".

93 “Art. 625-A. As empresas e os sindicatos podem instituir Comissões de Conciliação Prévia, de composição paritária, com representante dos empregados e dos empregadores, com a atribuição de tentar conciliar os conflitos individuais do trabalho. Parágrafo único. As Comissões referidas no caput deste artigo poderão ser constituídas por grupos de empresas ou ter caráter intersindical".
} 
Ao refletir mais profundamente sobre a questão, é possível colocar em xeque o sentido a ser empregado aos termos "bons ofícios e persuasão" na atuação dos magistrados, o que pode ser temerário para a eficácia do Direito do Trabalho e sua afirmação enquanto espécie dos direitos humanos.

O principal papel do juiz é dizer o direito, distribuir a justiça, o que não pode ser considerado razoável diante de uma atuação voltada a convencer as partes de que elas devem conciliar. Que a conciliação constitui um importante meio a ser considerado para a resolução de conflitos é inegável, mas ela deve ser requerida pelas partes, e não precedida pelo convencimento de que deve ser utilizada.

Afinal, o empregado, que corresponde ao polo ativo da esmagadora maioria de reclamações trabalhistas, se socorre à Justiça do Trabalho para ver seus direitos garantidos, ver o respeito ao trabalho executado e sua dignidade restaurada.

Os próprios empregadores, em muitos casos, se fecham à conciliação para não criar precedentes a eventuais futuras ações. Significa dizer que, se as partes realmente desejarem conciliar, elas demonstrarão interesse quando questionadas pelo magistrado por ocasião da audiência. Neste ponto, é importante o papel do juiz enquanto conciliador, ou seja, a partir do momento em que o exercício de tal papel é aceito pelas partes, após as indagações feitas pelo magistrado por ocasião da audiência.

$\mathrm{Na}$ condição de conciliador, porém, cabe ao magistrado zelar pelos direitos questionados judicialmente, sob pena de colaborar com o crescente processo de banalização dos direitos trabalhistas, fato que desencadeia a cultura de ser uma grande opção aos empregadores desrespeitar as garantias contidas no ordenamento jurídico. Afinal, poderão pagar, de maneira parcelada, um valor inferior ao realmente devido, seja no início da ação ou em sua fase executória.

Nos últimos anos, o país tem acompanhado a preocupante intensificação da política pela conciliação.

O Conselho Nacional de Justiça, órgão do Poder Judiciário criado recentemente $^{94}$, tem demonstrado, como um dos pontos principais de sua atuação, uma

\footnotetext{
${ }^{94}$ O Conselho Nacional de Justiça foi criado a partir da Emenda Constitucional 45, de 2004, com previsão constante do art. 92, I-A, da Constituição Federal. Sua composição está expressa no art. 103-B da Lei Maior,
} 
forte dedicação institucional à resolução dos conflitos judiciais por meio de acordos. Tal órgão promoveu o Movimento pela Conciliação, realizado em todo o país a partir de 2006, iniciando-se com a frase de efeito "Conciliar é legal!" 95.

De lá para cá, a promoção da conciliação aumentou significativamente. O discurso institucional enaltecedor de tal prática propiciou um processo traduzido por uma coação verticalizada, partindo do Conselho Nacional de Justiça, seguindo para os diversos tribunais existentes no país e, por fim, chegando aos jurisdicionados por meio dos magistrados.

A Resolução $125 / 2010^{96}$, baixada pelo Conselho Nacional de Justiça, utilizando-se do art. $5^{\circ}, \mathrm{XXXV}$, da Constituição Federal, como um de seus fundamentos, regulamenta a política de tratamento adequado do conflito de interesses no âmbito do Poder Judiciário. Além disso, determina que os tribunais criem Núcleos Permanentes de Métodos Consensuais de Solução de Conflitos (art. $7^{\circ}$ ), Centros Judiciários de Solução de Conflitos e Cidadania (art. $8^{\circ}$ ), entre outros. competindo-lhe, conforme preconiza o $\S 4^{\circ}$ do referido artigo: "o controle da atuação administrativa e
financeira do Poder Judiciário e do cumprimento dos deveres funcionais dos juízes, cabendo-lhe, além de
outras atribuições que lhe forem conferidas pelo Estatuto da Magistratura: I - zelar pela autonomia do Poder
Judiciário e pelo cumprimento do Estatuto da Magistratura, podendo expedir atos regulamentares, no âmbito
de sua competência, ou recomendar providências; II - zelar pela observância do art. 37 e apreciar, de ofício
ou mediante provocação, a legalidade dos atos administrativos praticados por membros ou órgãos do Poder
Judiciário, podendo desconstituí-los, revê-los ou fixar prazo para que se adotem as providências necessárias
ao exato cumprimento da lei, sem prejuízo da competência do Tribunal de Contas da União; III - receber e
conhecer das reclamações contra membros ou órgãos do Poder Judiciário, inclusive contra seus serviços
auxiliares, serventias e órgãos prestadores de serviços notariais e de registro que atuem por delegação do
poder público ou oficializados, sem prejuízo da competência disciplinar e correicional dos tribunais, podendo
avocar processos disciplinares em curso e determinar a remoção, a disponibilidade ou a aposentadoria com
subsídios ou proventos proporcionais ao tempo de serviço e aplicar outras sanções administrativas,
assegurada ampla defesa; IV - representar ao Ministério Público, no caso de crime contra a administração
pública ou de abuso de autoridade; V - rever, de ofício ou mediante provocação, os processos disciplinares de
juízes e membros de tribunais julgados há menos de um ano; VI - elaborar semestralmente relatório
estatístico sobre processos e sentenças prolatadas, por unidade da Federação, nos diferentes órgãos do Poder
Judiciário; VII - elaborar relatório anual, propondo as providências que julgar necessárias, sobre a situação
do Poder Judiciário no País e as atividades do Conselho, o qual deve integrar mensagem do Presidente do
Supremo Tribunal Federal a ser remetida ao Congresso Nacional, por ocasião da abertura da sessão
legislativa".

95 BRASIL. Conselho Nacional de Justiça. Conciliar é legal. Disponível em $<$ http://www.cnj.jus.br/images/programas/movimento-pela-conciliacao/artigo_01.pdf>. Acesso em 08/06/2012.

96 BRASIL. Conselho Nacional de Justiça. Resolução 125/2010. Dispõe sobre a Política Judiciária Nacional de tratamento adequado dos conflitos de interesses no âmbito do Poder Judiciário e dá outras providências. Disponível em <http://www.cnj.jus.br/atos-administrativos/atos-da-presidencia/resolucoespresidencia/12243resolucao-no-125-de-29-de-novembro-de-2010>. Acesso em 08/06/2012. 
Porém, o ponto mais importante de tal resolução para a pesquisa ora realizada diz respeito ao anexo denominado "Código de Ética de Conciliadores e Mediadores Judiciais", sobretudo o seu art. $2^{\circ}, \S 3^{\circ}$, que dispõe sobre o "dever de não forçar um acordo e de não tomar decisões pelos envolvidos, podendo, quando muito, no caso da conciliação, criar opções, que podem ou não ser acolhidas por eles", chamado pelo dispositivo como "ausência de obrigação de resultado". Trata-se de um ponto importantíssimo a ser observado, mas que infelizmente encontra algumas contradições no âmbito normativo oriundo do próprio $\mathrm{CNJ}$.

Com efeito, a Resolução 106/2010 ${ }^{97}$, também baixada pelo Conselho Nacional de Justiça, ao dispor sobre vários critérios a serem considerados para a promoção dos magistrados, prevê, no art. $6^{\circ}$ :

$\mathrm{Na}$ avaliação da produtividade serão considerados os atos praticados pelo magistrado no exercício profissional, levando-se em conta os seguintes parâmetros: (...) II - Volume de produção, mensurado pelo: (...) b) número de conciliações realizadas.

Outro ponto que pode ser destacado constitui a criação, pelo $\mathrm{CNJ}$, do prêmio "Conciliar é Legal"98, que incentiva e homenageia trabalhos destacados no que diz respeito à conciliação. Veja-se publicação disponível no sítio eletrônico do órgão mencionado:

Os três tribunais que conseguiram fechar maior número de acordos durante a $6^{\text {a }}$ Semana Nacional de Conciliação - Tribunal de Justiça de Goiás (TJGO), Tribunal Regional Federal da $1^{\text {a }}$ Região (TRF 1), e Tribunal Regional do Trabalho da $14^{\mathrm{a}}$ Região (TRT 14) - homologaram, juntos, 34 mil acordos, totalizando, em valores, R\$ 97.669.996,33. Os dados foram divulgados nesta quarta-feira (14/12), no Conselho Nacional de Justiça $(\mathrm{CNJ})$ e renderam a estes tribunais o Prêmio Conciliar é Legal, do CNJ, concedido aos órgãos do Judiciário que mais praticaram a

${ }^{97}$ BRASIL. Conselho Nacional de Justiça. Resolução 106/2010. Dispõe sobre os critérios objetivos para aferição do merecimento para promoção de magistrados e acesso aos Tribunais de $2^{\circ}$ grau. Disponível em $<$ http://www.cnj.jus.br/atos-administrativos/atos-da-presidencia/resolucoespresidencia/12224-resolucao-no106-de-06-de-abril-de-2010>. Acesso em: 08/06/2012.

${ }^{98}$ BRASIL. Conselho Nacional de Justiça. II Prêmio Conciliar é legal será entregue nesta quarta-feira. Disponível em <http:///www.cnj.jus.br/noticias/cnj/17515:ii-premio-conciliar-e-legal-sera-entregue-nestaquarta-feira>. Acesso em 08/06/2012. 
conciliação na resolução de litígios. No caso do Tribunal de Justiça de Goiás o Prêmio Conciliar é Legal foi entregue pelo segundo ano consecutivo. A corregedora Nacional de Justiça, ministra Eliana Calmon, elogiou o esforço do tribunal goiano, considerado um dos mais atuantes na prática da conciliação. "Eles sempre se saem muito bem em nossas avaliações. Fico feliz pelo empenho; essa é uma boa disputa", disse a corregedora, na cerimônia de entrega dos prêmios, no plenário do CNJ. No total, o TJGO formalizou 28 mil audiências de conciliação e celebrou mais de 22 mil acordos, com valores próximos a $\mathrm{R} \$ 30$ milhões. $\mathrm{O}$ tribunal também recebeu Menção Honrosa pelo Projeto Show Amigos da Paz, um show voltado para a pacificação social. "Pensamos numa forma de divulgar a conciliação e conseguimos envolver os jovens ao divulgar o show nas escolas municipais, estaduais e privadas", explicou a juíza coordenadora da conciliação nos juizados especiais daquele tribunal, Doraci Lamar ${ }^{99}$.

Vê-se, pois, a contradição existente na postura institucional do Conselho Nacional de Justiça quanto à importância conferida às práticas conciliatórias. Se, por um lado, consagra-se a impossibilidade de se "forçar" um acordo, por outro, tem-se o número de conciliações como indicativo a ser considerado para fins de promoção dos magistrados, além de se criar um prêmio que leva em conta, basicamente, valores e números de acordos.

Assim, a conciliação é uma tendência cada vez maior do Judiciário, que institucionaliza indiretamente os mecanismos conciliatórios de maneira coativa, evidenciando a fraqueza do Estado e o fato de que a justiça representa um valor que tem sido ignorado.

Não obstante, colocar os tribunais em graus comparativos no que diz respeito aos números de conciliações é render-se à prática comum de concorrência levada a efeito na esfera privada.

Porém, trata-se de uma saída para esquivar o Estado de rever a estrutura do Poder Judiciário. Se os números são tão importantes, o grande passo de partida é aumentar o efetivo de servidores e juízes e melhorar a estrutura oferecida aos jurisdicionados.

\footnotetext{
${ }^{99}$ BRASIL. Conselho Nacional de Justiça. Tribunais recebem prêmio por desempenho na resolução de conflitos. Disponível em <http://www.cnj.jus.br/noticias/cnj/17548:tribunais-recebem-premio-por-metas-naconciliacao\&catid=223:cnj>. Acesso em 08/06/2012.
} 
Portanto, a intensa política de conciliação deve ser vista como mais um grande aliado do processo de desregulamentação do Direito do Trabalho, uma vez que o empregado tende a ser prejudicado por sujeitar-se ao ente estatal revestido de um papel que privilegia o acordo, a começar pela própria legislação, intensificando-se com as políticas institucionais encampadas, e o empregador, na posição favorável de possibilidade de ver reduzidos os créditos a que o autor teria direito, os quais podem ser parcelados sem qualquer pagamento de custas processuais. Tudo sob a chancela do Poder Judiciário.

Não significa dizer, porém, que a Justiça do Trabalho é a única responsável pela plena efetivação do Direito do Trabalho. Afinal, sua atuação encontra limitações de ordem legal, mas está permeada pela inquestionável possibilidade de se esgotar a interpretação benéfica ao trabalhador, consagrada como princípio do Direito do Trabalho. Tal atuação deve-se pautar, diuturnamente, na lógica de efetivação da justiça social, que traz consigo a noção de compensação de bens e vantagens, caminhando no sentido da justiça distributiva, abordada oportunamente. Maior do que a vocação conciliatória deve ser a atuação contramajoritária da Justiça do Trabalho, enquanto ramo especializado que pode, indubitavelmente, desempenhar um papel fundamental na valorização dos trabalhadores, pela valorização da dignidade que lhes é inerente e, ao mesmo tempo, ignorada. 


\section{CONCLUSÕES}

O gênero dos direitos sociais se encontra num estado de verdadeira e intensa privatização, de maneira que a concretização das garantias a ele inerentes se dista cada vez mais das mãos do Estado. Tal processo, portanto, não é diferente em se tratando do Direito do Trabalho.

Bauman afirma que a modernidade líquida assiste à separação do poder e da política, apontando, assim, para uma possibilidade de leitura da atual situação do Direito do Trabalho no país.

A distância entre a aplicação da lei e as necessidades sociais é intensificada pelo divórcio acima apontado, de maneira que, por mais que os trabalhadores sejam agraciados com garantias normativas no campo das relações trabalhistas, não se vê uma eficácia condizente com todo o arcabouço hipotético que lhes é conferido.

Partindo-se da perspectiva de Bauman acerca dos Direitos Humanos, é possível concluir que o Direito do Trabalho tem atendido ao caráter instrumental de tais direitos e que o Poder Judiciário, mediante a atuação institucional em face dos dissídios que lhe são apresentados, representa um grande facilitador de tal processo, especialmente se considerada a política conciliatória intensificada nos últimos anos.

A afirmação de que o Direito do Trabalho integra o ramo do Direito Público reside, sobretudo, no âmbito formal, uma vez que, de fato, o conjunto de garantias conferidas aos trabalhadores está cada vez mais entregue à desregulamentação, o que o coloca materialmente em nítida seara privada, à mercê dos interesses havidos entre os particulares, tudo numa relação de forças, o que evidentemente implica a ausência de poder por parte dos empregados, intensificando a nítida polarização entre estes e seus empregadores.

Afinal, as garantias mínimas conferidas pelo Estado não são observadas e, quando a discussão chega até o Poder Judiciário, o empregado se depara com uma situação de total vulnerabilidade, que o leva, muitas vezes, a renunciar aos seus direitos, avençando um acordo que estimula o aumento sucessivo e contínuo do desrespeito às garantias previstas pelo ordenamento jurídico. 
Aplicar a ótica simplista dos Direitos Humanos, a mesma da Declaração Universal dos Direitos Humanos e vários outros diplomas do gênero, ao Direito do Trabalho, é um exercício hábil a classificar este último enquanto integrante do primeiro. Porém, insuficiente.

Equivoca-se, primeiramente, ao ler os Direitos Humanos enquanto mero produto consagrador de princípios exaltantes da dignidade humana, os quais, por força de uma mitigação resultante de um processo histórico de luta, transcendem o caráter simplista que comumente é conferido nas reflexões sobre os mesmos.

Todavia, se considerada a perspectiva traçada por Bauman quanto aos Direitos Humanos, permeada pelo contexto de modernidade líquida, pode-se identificar um retrato social delimitado: o caráter utilitarista de tais direitos, voltado à manutenção do "status quo", está perfeitamente relacionado ao Direito do Trabalho, pois este pode até nortear formalmente para a essência dos direitos sociais, mas na prática se desloca significativamente dela.

Assim, o resultado da subtração entre a essência dos direitos sociais e o Direito do Trabalho enquanto ferramenta distributiva apresenta, como substrato, uma realidade dissimulada, na qual as forças convergem para que o empregado continue a suportar todos os riscos e ônus das atividades exercidas pelo seu empregador.

Afirma-se o acesso ao trabalho, mas não se questiona que tipo de trabalho se pretende e as formas pelas quais o Estado pode, por meio das diversas instâncias de poder, voltar seus olhos aos trabalhadores, garantindo-lhes condições dignas de sobrevivência.

Os problemas estruturais encontrados convergem para o sentido de que desrespeitar a proteção legal do trabalhador é um bom negócio no Brasil.

Assim, a realidade propicia um processo deslegitimador da regulamentação encontrada no ordenamento jurídico.

Não obstante, o Poder Judiciário tem suas funções limitadas ao ordenamento jurídico e, embora não seja suficiente para efetivar o Direito do Trabalho, pode exercer o papel de contribuir com a aquisição de poder pelos trabalhadores, construindo uma jurisprudência em sintonia com os Direitos Humanos sob a perspectiva de 
luta e revendo a política conciliatória desenfreada que tem sido praticada. A materialização da hipótese ora levantada pode colaborar com a construção de uma consciência de classe.

A almejada emancipação está, em última instância, nas mãos dos trabalhadores, pois foge das limitações que cercam as instituições estatais ou sindicais. Mas o Estado ainda pode colaborar com o processo, conforme as possibilidades anunciadas no decorrer da pesquisa. O primeiro passo é deixar de pender para o polo detentor do poder no âmbito das relações laborais, construir um sentido valorizador da dignidade, atribuindo um novo significado ao Direito do Trabalho sem ignorar o verdadeiro campo de luta em que se insere a trajetória de busca pela efetivação dos Direitos Humanos. Afinal, viu-se a insuficiência da visão que se limita a ser compensatória no que diz respeito à efetivação dos direitos sociais, sendo imprescindível que se realize, no campo do Direito, uma mudança metodológica de maneira a equilibrar as estruturas econômica e social. É preciso traçar uma perspectiva, sobretudo, inclusiva, diferente de tudo aquilo a que a sociedade tem assistido há muito tempo e com maior intensidade na chamada modernidade líquida, a fim de que se elimine a exclusão como forte integrante do cenário plasmódico existente.

\author{
Realizar algo de útil \\ Quando li que queimavam as obras \\ Dos que procuravam escrever a verdade \\ Mas ao tagarela George, o de fala bonita, convidaram \\ Para abrir sua Academia, desejei mais vivamente \\ Que chegue enfim o tempo em que o povo solicite a um homem desses \\ Que num dos locais de construção dos subúrbios \\ Empurre publicamente um carrinho de mão com cimento, para que \\ Ao menos uma vez um deles realize algo de útil, com o que \\ Poderia então retirar-se para sempre \\ Para cobrir o papel de letras \\ Às custas do \\ Rico povo trabalhador ${ }^{100}$.
}

${ }^{100}$ BRECHT, Bertolt. Poemas 1913-1956. Trad.: Paulo César de Souza. São Paulo: Ed. 34, 2000. p. 100. 


\section{REFERÊNCIAS BIBLIOGRÁFICAS}

BAUMAN, Zygmunt. Comunidade: a busca por segurança no mundo atual. Rio de Janeiro: Jorge Zahar, 2003.

Modernidade Líquida. Rio de Janeiro: Zahar, 2001.

Vida a crédito: conversas com Citlali Rovirosa-Madrazo. Tradução de Alexandre Werneck. Rio de Janeiro: Jorge Zahar, 2010.

BENEVIDES, Maria Victoria de Mesquita et al. Democracia e República: Homenagem a Fábio Konder Comparato. São Paulo: Quartier Latin, 2009.

BERMAN, Harold J. Direito e Revolução - a formação da Tradição Jurídica Ocidental. São Leopoldo: Editora Unisinos. 2006.

BLACKBURN, R. The overthrow of colonial slavery. New York: Verso, 2000.

BRASIL. Ato das Disposições Constitucionais Transitórias de 1988.

. Constituição Federal, 1988.

Conselho Nacional de Justiça. Conciliar é legal. Disponível em $<$ http://www.cnj.jus.br/images/programas/movimento-pela-conciliacao/artigo_01.pdf $>$. Acesso em 08/06/2012.

Conselho Nacional de Justiça. Resolução 125/2010. Dispõe sobre a Política Judiciária Nacional de tratamento adequado dos conflitos de interesses no âmbito do Poder Judiciário e dá outras providências. Disponível em <http://www.cnj.jus.br/atosadministrativos/atos-da-presidencia/resolucoespresidencia/12243-resolucao-no-125-de-29de-novembro-de-2010>. Acesso em 08/06/2012.

. Conselho Nacional de Justiça. Resolução 106/2010. Dispõe sobre os critérios objetivos para aferição do merecimento para promoção de magistrados e acesso aos Tribunais de $2^{\circ}$ grau. Disponível em <http://www.cnj.jus.br/atos-administrativos/atos-dapresidencia/resolucoespresidencia/12224-resolucao-no-106-de-06-de-abril-de-2010>.

Acesso em: 08/06/2012.

Conselho Nacional de Justiça. II Prêmio Conciliar é legal será entregue nesta quarta-feira. Disponível em <http:///www.cnj.jus.br/noticias/cnj/17515:ii-premioconciliar-e-legal-sera-entregue-nesta-quarta-feira>. Acesso em 08/06/2012.

Conselho Nacional de Justiça. Tribunais recebem prêmio por desempenho

na resolução de conflitos. Disponível em $<$ http://www.cnj.jus.br/noticias/cnj/17548:tribunais-recebem-premio-por-metas-naconciliacao\&catid=223:cnj>. Acesso em 08/06/2012. 
Lei $n^{\circ} 11.770$, de 9 de setembro de 2008. Cria o programa Empresa Cidadã, destinado à prorrogração da licença-maternidade mediante concessão de incentivo fiscal, e altera a Lei ${ }^{\circ}$ 8212, de 24 de julho de 1991. Diário Oficial da União. Brasília, DF, 10 set. 2008.

. Ministério da Saúde. Secretaria Executiva. Sistema Único de Saúde (SUS): princípios e conquistas. Brasília: Ministério Saúde, 2000.

Ministério do Trabalho e Emprego. NR-31 Segurança e Saúde no Trabalho na Agricultura, Pecuária, Silvicultura, Exploração Florestal e Aquicultura. Disponível em: <http://portal.mte.gov.br/data/files/8A7C812D33EF459C0134561C307E1E94/NR31\%20(atualizada\%202011).pdf>. Acesso em 14.mai.2012.BRASIL. Presidência. Fome Zero. Disponível em: <www.fomezero.gov.br/o-que-e>. Acesso em 20 junho 2011.

. Tribunal Regional do Trabalho da $15^{\mathrm{a}}$ Região. Disponível em: <http://www.trt15.jus.br/consulta/owa/documento.pdf?pAplicacao=DOCASSDIG\&pid=47 02037>. Acesso em 14.05.2012.

. Tribunal Regional do Trabalho da $23^{\mathrm{a}}$ Região. Diário Eletrônico da Justiça do Trabalho. n. 472/2010, 5 mai. 2010.

Tribunal Superior do Trabalho. RR - 294-59.2010.5.03.0142 , Relator Ministro: José Roberto Freire Pimenta, Data de Julgamento: 25/04/2012, $2^{\text {a }}$ Turma, Data de Publicação: 04/05/2012.

Tribunal Superior do Trabalho. RR - 116100-55.2003.5.05.0491, Relator Ministro: José Roberto Freire Pimenta, Data de Julgamento: 25/04/2012, $2^{\mathrm{a}}$ Turma, Data de Publicação: 04/05/2012.

Tribunal Superior do Trabalho. RR - 15000-41.2005.5.15.0125 , Relator Ministro: Aloysio Corrêa da Veiga, Data de Julgamento: 04/11/2009, $6^{\text {a }}$ Turma, Data de Publicação: 13/11/2009.

Tribunal Superior do Trabalho. RR - 847-52.2010.5.15.0052 , Relator Ministro: Alberto Luiz Bresciani de Fontan Pereira, Data de Julgamento: 14/12/2011, $3^{a}$ Turma, Data de Publicação: 19/12/2011.

CESARINO JÚNIOR, Antonio Ferreira. Direito Social Brasileiro. 6.ed. São Paulo: Saraiva, 1970.

COMPARATO, Fábio Konder. A afirmação histórica dos direitos humanos. 6.ed. São Paulo: Saraiva, 2008.

Ética: direito, moral e religião no mundo moderno. São Paulo: Companhia das Letras, 2006.

DEPARTAMENTO INTERSINDICAL DE ESTATÍSTICA E ESTUDOS SOCIOECONÔMICOS. Quanto se trabalha para comer. Disponível em: <http://www.dieese.org.br/rel/rac/trajun11.xml\#tabelao>. Acesso em 04 jul. 2011. 
Salário mínimo nominal e necessário. Disponível em: <http://www.dieese.org.br/rel/rac/salminMenu09-05.xml>. Acesso em 04 jul. 2011.

DUMAZEDIER, Joffre. Lazer e Cultura Popular. São Paulo: Perspectiva, 1973.

FRENCH, John D. Afogados em leis: a CLT e a cultura política dos trabalhadores brasileiros. Trad. Paulo Fontes. São Paulo: Editora Fundação Perseu Abramo, 2001.

FURTADO, Celso. Formação Econômica do Brasil. São Paulo: Companhia das Letras, 2007.

GORCZEVSKI, Clovis. Direitos Humanos. Dos primórdios da humanidade ao Brasil de hoje. Porto Alegre: Imprensa Livre, 2005.

INSTITUTO BRASILEIRO DE GEOGRAFIA E ESTATÍSTICA. Dados sobre a educação no Brasil. $\quad$ Disponível em: http://www.ibge.gov.br/ibgeteen/datas/escola/dados.html>. Acesso em 20 julho 2011.

$\overline{\text { Disponível }}$ em: < http://www.ibge.gov.br/home/presidencia/noticias/noticia_visualiza.php?id_noticia=600>. Acesso em 20 julho 2011.

LAFER, Celso. A reconstrução histórica dos direitos humanos: um diálogo com o pensamento de Hannah Arendt. São Paulo: Companhia das Letras, 1988.

LOPES, José Reinaldo de Lima. Direitos Sociais: Teoria e Prática. São Paulo: Método, 2006.

MAGALHAES, José Luiz Quadros de. Direitos Humanos. Sua história, sua garantia e a questão da indivisibilidade. São Paulo: Juarez de Oliveira, 2000.

MARTINS, Sérgio Pinto. Direitos fundamentais trabalhistas. São Paulo: Atlas, 2008.

MARTINS FILHO, Ives Gandra da Silva. Manual de Direito e Processo do Trabalho. 18.ed. São Paulo: Saraiva, 2009.

OBSERVATÓRIO DE SEGURANÇA PÚBLICA. Análise da Criminalidade em São Paulo. Disponível em: <http://www.observatoriodeseguranca.org/dados/dados/agregadas $>$. Acesso em: 20 julho 2011.

POSNER, Richard A. Problemas de Filosofia do Direito. São Paulo: Martins Fontes, 2007.

QUEIROZ JÚNIOR, Hermano. Os direitos fundamentais dos trabalhadores na Constituição de 1988. São Paulo: LTr, 2006.

ROMITA, Arion Sayão. Direitos fundamentais nas relações de trabalho. 3.ed. São Paulo: LTr, 2009. 
SEMINÁRIO DIREITOS HUMANOS DAS MULHERES: A PROTEÇÃO INTERNACIONAL. 25 de maio de 2000. Câmara dos Deputados. Brasília. Disponível em: $<$ http://www.dhnet.org.br/direitos/militantes/cancadotrindade/cancado_bob.htm $>$.Acesso em: 20 julho 2011.

SÓFOCLES. Antígona (Trad. Millôr Fernandes). São Paulo: Paz e Terra, 2003.

STIGLITZ, Joseph E. Globalização: como dar certo. Trad.: Pedro Maia Soares. São Paulo: Companhia das Letras, 2007.

SUSSEKIND, Arnaldo. Curso de Direito do Trabalho. 3.ed. Rio de Janeiro: Renovar, 2010.

WEIS, Carlos. Os direitos humanos contemporâneos. São Paulo: Malheiros, 1999. 


\title{
ANEXO I
}

A C Ó R D $\tilde{A} O$

\section{2 a Turma \\ GMJRP / Ibm}

\begin{abstract}
TURNO
ININTERRUPTO

$\mathrm{DE}$

REVEZAMENTO. HORAS EXTRAS. ELASTECIMENTO DA JORNADA POR ACORDO COLETIVO. VALIDADE. NÃO CARACTERIZAÇÃO DE MERA RENÚNCIA.
\end{abstract}

Nos termos da Súmula n 423 desta Corte, "estabelecida jornada superior a seis horas e limitada a oito horas por meio de regular negociação coletiva, os empregados submetidos a turnos ininterruptos de revezamento não têm direito ao pagamento da $7^{\mathrm{a}}$ e $8^{\mathrm{a}}$ horas como extra". No caso, o elastecimento da jornada de trabalho está fundamentada em norma coletiva. Desse modo, incide à hipótese o teor da Súmula no 423 do Tribunal Superior do Trabalho, não havendo cogitar de conflito com a Orientação

Jurisprudencial no 360 da SBDI-1, como pretende 0 reclamante, ora recorrente.

Recurso de revista não conhecido.

Vistos, relatados e discutidos estes autos de Recurso de Revista ${ }^{\circ}$ TST-RR-294-59.2010.5.03.0142, em que é Recorrente CLEITON RAIMUNDO DE SOUSA e Recorrido FIAT AUTOMÓVEIS S.A.

O Tribunal Regional do Trabalho da $3^{a}$ Região deu parcial provimento ao recurso ordinário interposto pela reclamada para excluir da condenação as $7^{a}$ e $8^{a}$ horas extras diárias e consectários reflexos.

Contra esse acórdão, o reclamante interpõe recurso de revista, às págs. 418-422 (autos digitalizados), no qual sustenta, em síntese, contrariedade à Orientação 
Jurisprudencial n॰ 360 da SBDI-1 do Tribunal Superior do Trabalho.

- recurso foi admitido pelo despacho de págs. 427-431 (autos digitalizados).

A reclamada apresentou contrarrazões ao

recurso às págs. 433-457 (autos digitalizados).

Os autos não foram remetidos ao Ministério

Público do Trabalho ante o disposto no art. 83 do Regimento

Interno do Tribunal Superior do Trabalho

É o relatório.

\section{$\mathrm{V} \circ \mathrm{T} O$}

TURNO ININTERRUPTO DE REVEZAMENTO. HORAS

EXTRAS. ELASTECIMENTO DA JORNADA POR ACORDO COLETIVO.

VALIDADE. NÃO CARACTERIZAÇÃO DE MERA RENÚNICA.

\section{CONHECIMENTO}

- Tribunal Regional do Trabalho da $3^{a}$

Região deu parcial provimento ao recurso ordinário interposto pela reclamada para excluir da condenação as $7^{a}$ e $8^{a}$ horas extras diárias e consectários reflexos, com base nos seguintes fundamentos:

“TURNOS ININTERRUPTOS DE REVEZAMENTO (RECURSO DA RECLAMADA)

$\underline{\mathrm{O} \text { debate refere-se à jornada praticada pelo autor em dois }}$ turnos, insistindo a recorrente não se tratar de turnos ininterruptos de revezamento.

Ataca o posicionamento originário argumentando que o autor não trabalhava no referido sistema, porque embora a espécie de jornada praticada seja de revezamento, não poderia ser considerado ininterrupto, em razão de seu labor não abarcar as 24 horas do dia.

Assim, refuta a aplicação da OJ 360 do TST.

Argumenta, outrossim, que ainda que se considerasse a jornada praticada de turnos ininterruptos de revezamento, não poderia o reclamante, fazer jus à jornada reduzida em razão da 
existência de norma coletiva que fixa a jornada em dois turnos laborada superior a 06 horas.

Nessa linha de idéias, segue sustentando, não poder o MM. Juiz de origem desconsiderar as normas coletivas anexas.

Sustenta que O ACT firmado em 17/12/1997 entre a ora recorrente e o Sindicato da categoria estipulou em sua cláusula $3^{\text {a }}$ que cada turno teria jornada específica, quais sejam: 44 horas semanais para o primeiro turno, 41 horas semanais para $o$ segundo turno e 37 horas para o terceiro, ao passo que todos os funcionários receberiam como se estivessem laborando 44 horas semanais.

Por cautela, acaso vencidos seus argumentos, requer, sucessivamente, que a condenação limite-se ao pagamento do adicional de horas extras, alegando ter o autor recebido todas as horas trabalhadas, de forma simples, porque contratado, para trabalhar por 44 horas semanais como horista.

Examina-se.

Segundo entendimento originário, ao reclamante foram deferidas as horas extras excedentes à $6^{\mathrm{a}}$ diária do período de vigência contratual até maio/2009.

É incontroverso que o autor trabalhou, pelo período contratual, em sua quase totalidade, em 02 turnos, com os horários das, 06:00 às 15:48h e das 15:48 às 01:09h. Em alguns períodos chegou ainda a trabalhar em um $3^{\circ}$ turno.

É certo que, o turno ininterrupto de revezamento se caracteriza pela conjugação de dois pressupostos: a natureza ininterrupta do empreendimento empresarial e o labor em horários de trabalho alternados entre turnos diurnos e noturnos, de forma contínua.

Pontue-se que a jurisprudência pacificou o entendimento de que o trabalho em dois turnos alternados, alcançando parte do dia e da noite é suficiente paira a configuração de labor em turnos, ininterruptos de revezamento, o que supera a necessidade de, para tal configuração haver o labor em três turnos, alcançando as 24 horas do dia. Para tanto editou a OJ 360 da SBDI-1 do TST, in verbis:

'TURNO ININTERRUPTO DE REVEZAMENTO. DOIS TURNOS. HORÁRIO DIURNO E NOTURNO. CARACTERIZAÇÃO: Faz jus à jornada especial prevista no art. $7^{\circ}$, XIV, da $\mathrm{CF} / 1988$ o trabalhador que exerce suas atividades em sistema de alternância de turnos, ainda que em dois turnos de trabalho, que compreendam, no todo, ou em parte, o horário diurno e o noturno, pois submetido á alternância de horário prejudicial à saúde, sendo irrelevante que a atividade dá empresa se desenvolva de forma ininterrupta".

Como se vê, não há exigência para a caracterização do trabalho em turnos ininterruptos de revezamento, a prestação de serviços nos três turnos, de forma a completar o ciclo de 24 horas, bastando o labor em dois turnos diurno e noturno, o que, efetivamente, ocorria. 
Ressalte-se que a alternância de horários a que o autor estava sujeito é suficiente para desregular o seu relógio biológico, além de interferir no seu convívio familiar e social o que torna mais penosas as condições de trabalho. Mesmo podendo dormir parte da noite no horário de 15:48 às 01:09; não podemos esquecer que o horário médio, para que uma, pessoa não afete seu relógio biológico é em torno de 10:00 horas da noite, em média. Logo, esta média não era cumprida, na realidade era elastecida, indo o empregado dormir por volta de mais de 2:00 horas da manhã, se considerarmos o mínimo de tempo gasto para este empregado chegar em casa.

Além disso, a Constituição da Republica assegura em seu artigo $7^{\circ}$, inciso XIV, como direito dos trabalhadores, jornada de seis horas para o trabalho realizado em turnos ininterruptos de revezamento. Logo, o regime de trabalho em jornada ininterrupta possui contornos muito especiais, objeto de tratamento específico em dispositivo constitucional (inciso XIV artigo $7^{\circ}$ da $\mathrm{CR}$ ). Por essa, razão a extensão do horário de trabalho só seria admissível com previsão expressa em normas coletivas de vigência regular.

E analisando os autos, nesse aspecto, há norma coletiva que autoriza o trabalho em dois turnos com jornada superior a 06 horas. Essa autorização vigeu por todo o período de vigência do contrato do reclamante. O Acordo Coletivo de f. 128, firmado em 17/12/1997, teve vigência de um ano a partir de 05/01/1998 e a partir de cada vencimento, já que previa a prorrogação por períodos sucessivos de um ano, caso não houvesse manifestação contrária das partes. Desse instrumento, consta a jornada dos empregados que trabalhavam em 02 e 03 turnos, com revezamento semanal: $1^{\circ}$ turno, de segunda a sextafeira, de 06:00 às 15:18; $2^{\circ}$ turno, de segunda a sexta-feira, de 15:48 às 24:00; e $3^{\circ}$ turno, aos domingos; de 21:00 às 06:00, e de segunda a sexta-feira, de 24:00 às 06:00. Em 20/03/2000, firmou-se o Acordo Coletivo de f. 154, com jornada para os empregados em 02 turnos de revezamento, à saber: $1^{\circ}$ turno, de segunda a sexta-feira, de 06:00 às 15:18, e $2^{\circ}$ turno, de segunda a sexta-feira, de 15:18 às 24:00. Havia, pois, uma jornada semanal de 44 horas no $1^{\circ}$ turno e uma jornada semanal de 41 horas no $2^{\circ}$ turno, perfazendo a média plurissemanal de 42:30 horas efetivamente trabalhadas, sendo remuneradas 44 horas a cada semana. Esse Acordo foi ratificado pelo instrumento coletivo de 2001/2002 (f. 132), com vigência de um ano a partir de 20/03/2001 e por períodos sucessivos de um ano ao final, de cada vencimento, caso não houvesse manifestação contrária das partes. Por meio do termo aditivo de 30/08/2006 (f. 136), com vigência prorrogada até 30/09/2007, a ré se comprometeu a admitir empregado, convalidando o horário de trabalho fixado desde 2002: de 06:00 às 15:48 e de 15:48 às 01:09, em revezamento semanal. No Acordo de 2007 (f. 143), datado de 01/02/2007, e com vigência até 30/04/2008, as partes, 
considerando a ampliação da capacidade produtiva da ré, criaram um $3^{\circ}$ turno com duração semanal de 36:16, mas mantiveram os demais turnos nos horários já consagrados: de 06:00 às 15:48 e de 15:48 às 01:09. Essas normas gerais foram mantidas pelo Acordo de 2008/2009 (f. 145), com vigência de dois anos a partir de 28/05/2008. Após a edição da Orientação Jurisprudencial 360 do TST, a reclamada e o Sindicato profissional negociaram a realização de uma consulta direta sobre manutenção do sistema de turnos de revezamento ou sua substituição por turnos fixos. $\mathrm{O}$ resultado revelou a preferência de $92,72 \%$ dos empregados pela manutenção dos turnos alternantes, conforme se depreende do documento de f. 152. Assim, no caso em apreço, por existir norma coletiva que autoriza o trabalho em dois turnos com jornada superior a 06 horas, caberia razão à ré ao pleitear a exclusão das horas extras deferidas.

No entanto, a autorização para extensão da jornada, em norma coletiva, cobre parte do período trabalhado, ao fundamento, de que:

'No interregno compreendido entre o término da vigência do ACT firmado em março de 2001 (março de 2002) e agosto de 2006 nenhuma norma foi ajustada pela empresa com o fim de ratificar os horários referidos acima. Sendo, assim, não resta dúvida quanto ao cabimento das horas extras trabalhadas além do limite de seis horas diárias nessa época. No que toca ao ACT firmado em agosto de 2006, observo que a cláusula $3^{\text {a }}$ dispõe expressamente que o horário de 06:00 h às 15:48 h e de 15:48 h às 01:09 $\mathrm{h}$ permanecia em vigor. Logo, considerando a vigência dessa norma até setembro de 2007, até essa época existiu negociação eficaz, quanto ao tema, (f, 137). Nova ratificação dos horários em negociação coletiva ocorreu em maio de 2008 (f. 145/149)'.

Dessa forma, agiu com o costumeiro acerto o magistrado de $1^{\circ}$ grau, conforme delimitado em fundamentação f. 284/285.

Em razão das horas extras parcialmente acolhidas, quanto à pretensão de que seja deferido apenas o adicional de horas extras, entende-se que não cabe aplicar ao presente caso o entendimento consubstanciado na Súmula 85, III, do TST. Isso porque, não se verificou mero descumprimento das exigências legais para a Compensação de jornada, mas, sim, ausência de norma, coletiva autorizando, o elastecimento da jornada diária de 06 horas em turnos ininterruptos de revezamento.

Assim, afasto da condenação as $7^{\mathrm{a}}$ e $8^{\mathrm{a}}$ horas extras, por entender que os instrumentos coletivos carreados aos autos abrangem todo o período imprescrito.

Dou provimento" (págs. 406-410, autos digitalizados, grifou-se). 
Nas razões de revista, o reclamante alega tão somente, contrariedade à Orientação Jurisprudencial nº 360 da SBDI-1 do Tribunal Superior do Trabalho.

Argumenta que, no regime de turnos ininterruptos de revezamento, as horas trabalhadas após a $6^{a}$ devem ser pagas como extras, acrescidas do respectivo adicional e de todos os consectários legais.

Razão não assiste ao recorrente.

A Constituição Federal de 1988, ao mesmo tempo em que se preocupou em proteger os trabalhadores, estabelecendo limites para a jornada de trabalho em turnos ininterruptos de revezamentos, ressalvou o valor e o prestígio que os sindicatos e as negociações coletivas ganharam na sociedade e, consequentemente, no Direito do Trabalho atual, facultando às partes interessadas o ajuste de jornada diversa para a hipótese.

A par da norma específica que trata do tema, artigo 70, inciso XIV, da Carta Magna, o mesmo artigo, no inciso XXVI, assegura o reconhecimento das negociações coletivas, buscando a validação e o revigoramento da atuação sindical. No artigo $8^{\circ}$, inciso III, do mesmo Texto Constitucional, observa-se, ainda, clara a missão do sindicato de defender os interesses individuais e coletivos da categoria que representar.

Discute-se, nos autos, se, no trabalho em turnos com alternância de horários, de modo a atrair a jornada reduzida de seis horas prevista no inciso XIV do artigo $7^{\circ}$ da Constituição Federal, há possibilidade de afastar o pagamento das $7^{a}$ e $8^{a}$ horas suplementares mediante negociação coletiva, quando evidenciada a ausência de concessões recíprocas.

Consoante o disposto no artigo $7^{\circ}$, inciso XIV, da Constituição da República, os empregados submetidos ao turno ininterrupto de revezamento terão jornada de trabalho de seis horas diárias, salvo negociação coletiva.

De outro lado, esta Corte superior firmou entendimento de que, uma vez estabelecida jornada superior a seis horas e limitada a oito horas, mediante regular 


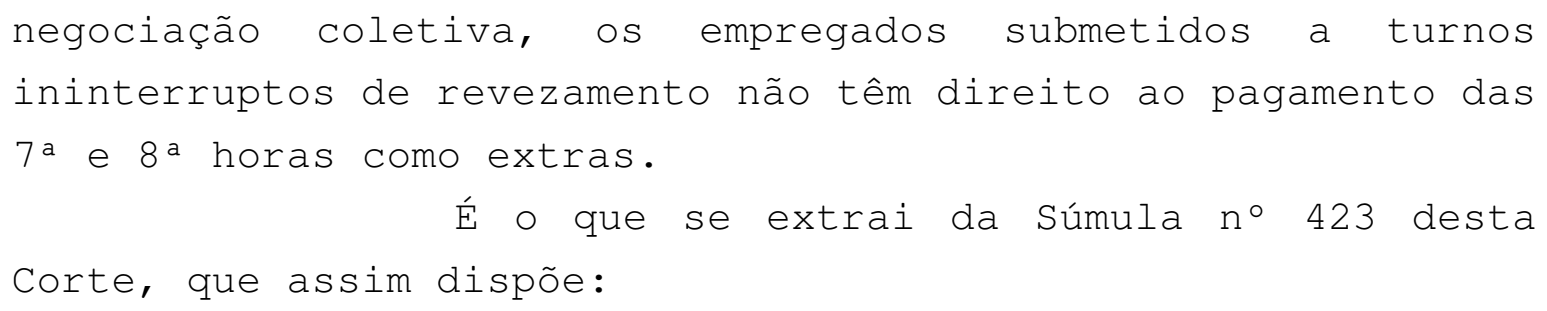

“TURNO ININTERRUPTO DE REVEZAMENTO. FIXAÇÃO DE JORNADA DE TRABALHO MEDIANTE NEGOCIAÇÃO COLETIVA. VALIDADE. (conversão da Orientação Jurisprudencial no 169 da SDI-I, Res. 139/06 - DJ 10.10.06)

Estabelecida jornada superior a seis horas e limitada a oito horas por meio de regular negociação coletiva, os empregados submetidos a turnos ininterruptos de revezamento não têm direito ao pagamento da $7^{\mathrm{a}}$ e $8^{\mathrm{a}}$ horas como extra".

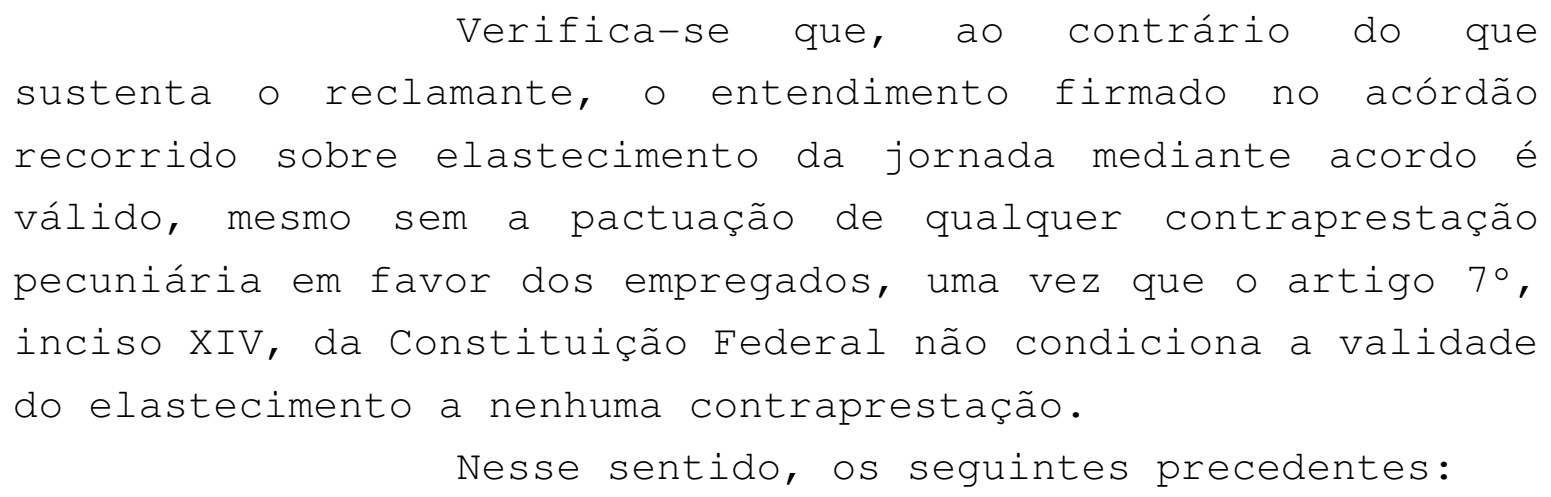

"RECURSO DE REVISTA. TURNO ININTERRUPTO DE REVEZAMENTO. HORAS EXTRAS. ELASTECIMENTO DA JORNADA. NORMA COLETIVA. VALIDADE. SÚMULA 423 DO TST. O Tribunal Regional adotou tese no sentido de que, mesmo diante de norma coletiva, a prorrogação de jornada em turnos ininterruptos acarreta o direito do trabalhador ao pagamento de sétima e oitava horas como extras, visto que não teria havido qualquer compensação pecuniária aos empregados. Por seu turno, o entendimento posto na Súmula 423 desta Corte é no sentido de que estabelecida jornada superior a seis horas e limitada a oito horas por meio de regular negociação coletiva, os empregados submetidos a turnos ininterruptos de revezamento não tem direito ao pagamento da $7^{\mathrm{a}}$ e $8^{\mathrm{a}}$ horas como extras. Ressalta-se, ainda, que, ao contrário do que concluiu o Tribunal a quo, o acordo é válido mesmo sem a pactuação de qualquer contraprestação pecuniária em favor dos empregados. Precedentes. Conhecido e provido." (RR129800-53.2008.5.15.0036, Relator Ministro Emmanoel Pereira, 5a Turma, DEJT 28/10/2010). 
"RECURSO DE REVISTA DA RECLAMADA. HORAS EXTRAS APÓS A $6^{\mathrm{a}}$ DIÁRIA. TURNOS DE REVEZAMENTO. ACORDO COLETIVO DE TRABALHO. I - O Tribunal Pleno do TST, chamado a emitir tese sobre o alcance e sentido do artigo $7^{\circ}$, inciso XIV, da Constituição e da então Orientação Jurisprudencial $n^{\circ} 169$ da SBDI-1, nos autos do Processo ${ }^{\circ}$ TST-E-RR-576.619/1999.9, fê-lo no sentido de que "uma vez estabelecida jornada superior a 6 (seis) horas por meio de regular negociação coletiva, os empregados submetidos a turnos ininterruptos de revezamento não têm direito ao pagamento das $7^{\mathrm{a}}$ e $8^{\mathrm{a}}$ horas como extras". II - Tanto que, após, foi editada a Súmula $n^{\circ} 423$ do TST, por meio da Resolução ${ }^{\circ}$ $139 / 2006$, pela qual se consolidou o entendimento de que "Estabelecida jornada superior a seis horas e limitada a oito horas por meio de regular negociação coletiva, os empregados submetidos a turnos ininterruptos de revezamento não têm direito ao pagamento das $7^{\mathrm{a}}$ e $8^{\mathrm{a}}$ horas como extras". III - Pela tese emitida pelo Pleno de que a Orientação Jurisprudencial $n^{\circ}$ 169 da SBDI-1 (atual Súmula $\mathrm{n}^{\circ} 423$ do TST) previu modalidade de transposição de jornada de trabalho, mediante negociação coletiva regular, fato incontroverso no caso concreto, não se há cogitar de horas extras, tendo a decisão recorrida contrariado o disposto no verbete. IV - Não se mostra sustentável o aspecto veiculado pela Turma Regional, no exame da reciprocidade da negociação, de ser necessária concessão de "contrapartida direta em razão do elastecimento da jornada de trabalho preconizada no art. $7^{\circ}$, XIV da Constituição". Isso porque, pelo prisma da teoria do conglobamento, presume-se que as concessões recíprocas derivam do acordo coletivo como um todo, e não pelo foco particular de cada matéria - no caso, a transposição da jornada de seis para a jornada de oito horas, objeto de negociação coletiva. Nesse sentido, precedentes deste Tribunal. IX - Recurso provido. (...)." (RR-4620053.2006.5.15.0021, Relator Ministro Antônio José de Barros Levenhagen, $4^{\text {a }}$ Turma, DEJT $15 / 10 / 2010$ ).

"RECURSO DE REVISTA. HORAS EXTRAS. TURNO ININTERRUPTO DE REVEZAMENTO. ELASTECIMENTO DA JORNADA DE TRABALHO. NEGOCIAÇÃO COLETIVA. AUSÊNCIA DE VANTAGEM PARA O EMPREGADO. VALIDADE. TEORIA DO CONGLOBAMENTO. Consoante firmado na Súmula 423 do TST, estabelecida jornada superior a seis horas e limitada a oito horas por meio de regular negociação coletiva, os empregados submetidos a turnos ininterruptos de revezamento não têm direito ao pagamento da $7^{\mathrm{a}}$ e $8^{\mathrm{a}}$ horas como extras. Na hipótese, o Tribunal Regional entendeu que, apesar de haver norma coletiva nesse sentido, não haveria como lhe conferir validade, 
porquanto não houve nenhuma contraprestação ao empregado pelo elastecimento da jornada de trabalho. O entendimento desta Turma é no sentido de que não há como considerar inválida norma coletiva que elasteceu a jornada de trabalho para os empregados que laboram em regime de turno ininterrupto de revezamento, ainda que não lhes tenha sido auferida nenhuma vantagem compensatória. Isso se deve porque, em face da Teoria do Conglobamento, o que deve ser analisado é se o conjunto das cláusulas do acordo ou da convenção coletiva é, ou não, benéfica ao trabalhador. Nesse contexto, merece reforma a decisão regional, a fim de excluir da condenação o pagamento, como hora extra, do tempo excedente à $6^{\mathrm{a}}$ hora diária, quando o trabalho ocorreu em turnos ininterruptos de revezamento. Recurso de revista de que se conhece e a que se dá provimento." (RR-19200-92.2004.5.15.0039, Relator Ministro Pedro Paulo Manus, DEJT $10 / 09 / 2010$ ).

"AGRAVO. TURNO ININTERRUPTO DE REVEZAMENTO. JORNADA DE OITO HORAS PREVISTA EM NORMA COLETIVA. EFEITOS. A respeito da possibilidade de elastecimento da jornada desenvolvida em turnos ininterruptos de revezamento de seis para oito horas, por meio de norma coletiva, o c. TST já sedimentou entendimento, em sentido positivo, conforme Súmula 423/TST. Destaque-se que a expressão -regular negociação- prevista nessa diretriz jurisprudencial diz respeito a aspecto formal na elaboração do ajuste, nada tendo a ver com o conteúdo material. Assim, não havendo outra exceção à validade da cláusula normativa, a qual não restou comprovada, correta a e. Turma ao decidir com base na Súmula 423/TST. E como já registrado no v. acórdão recorrido, a jurisprudência desta e. Subseção firmou-se também no sentido de que o acordo é válido, ainda que os trabalhadores não tenham nenhum benefício em contrapartida. Recurso de agravo a que se nega provimento." ( $A G-E-E D-R R-182600-$ 13.2002.5.15.0022, Relator Ministro: Horácio Raymundo de Senna Pires, Subseção I Especializada em Dissídios Individuais, Data de Publicação: 09/04/2010).

"RECURSO DE EMBARGOS INTERPOSTO ANTERIORMENTE À VIGÊNCIA DA LEI N. ${ }^{\circ}$ 11.496/2007. TURNOS ININTERRUPTOS DE REVEZAMENTO ELASTECIMENTO DA JORNADA DE TRABALHO POR MEIO DE ACORDO COLETIVO. EFICÁCIA DO ACORDO COLETIVO MESMO SEM A PACTUAÇÃO DE QUALQUER CONTRAPRESTAÇÃO. INDEVIDO O PAGAMENTO DAS 7. ${ }^{\mathrm{a}}$ E 8. ${ }^{\mathrm{a}}$ HORAS COMO EXTRAORDINÁRIAS. SÚMULA N. ${ }^{\circ} 423$ DO TST. 1. O art. 7. ${ }^{\circ}$, XIV, da Constituição Federal de 1988 estabelece jornada de seis horas para o trabalho realizado 
em turnos ininterruptos de revezamento, mas permite que a empresa fixe jornada superior a seis horas mediante negociação coletiva. 2. Ressalte-se que o acordo coletivo celebrado entre as partes tem força de lei, devendo por isso ser respeitado, conforme o disposto no art. 7. ${ }^{\circ}$, XXVI, da Carta Magna. 3. Dessarte, existindo acordo coletivo no sentido de estabelecer a jornada de 8 (oito) horas para trabalho realizado em turno ininterrupto de revezamento, não há de se falar em pagamento das 7. ${ }^{a}$ e $8 .^{a}$ horas como extraordinárias, pois, se assim não fosse, não haveria razão de ser da ressalva feita no inciso XIV do art. 7. ${ }^{\circ}$ da Carta Magna. 4. Registre-se, por fim, que, de acordo com o entendimento da SBDI-1 desta Corte, é válido o acordo coletivo que elastece a jornada de trabalho dos empregados sujeitos ao regime de turnos ininterruptos de revezamento, mesmo sem a pactuação de qualquer contraprestação em favor dos trabalhadores. Recurso de Embargos conhecido em parte e provido." (Processo: EED-RR - 147000-07.2001.5.15.0105 Data de Julgamento: 27/11/2008, Relatora Ministra: Maria de Assis Calsing, Subseção I Especializada em Dissídios Individuais, DEJT 19/12/2008) .

"TURNOS ININTERRUPTOS DE REVEZAMENTO. ELASTECIMENTO DA JORNADA. ACORDO COLETIVO. HORAS EXTRAS. ORIENTAÇÃO JURISPRUDENCIAL 169 DA SBDI-1 DO TST 1. Embora o sistema de trabalho em turnos ininterruptos de revezamento possa, em tese, prejudicar a integridade física e mental do empregado, comprometendo sua saúde e até seu convívio social, essa modalidade se situa no âmbito da flexibilização balizada pelos próprios limites traçados pelo legislador constituinte, que, no art. $7^{\circ}$, cuidou de discriminar aspectos do contrato de trabalho que podem ser flexibilizados, a saber: salários (inc. VI), duração da jornada normal (compensação e elastecimento, inc. XIII) e duração da jornada nos turnos ininterruptos de revezamento (inc. XIV). 2. Portanto, conquanto o prestígio e o status constitucional da negociação coletiva inscritos no art. $7^{\circ}$, inc. XXVI, da Constituição da República, não devam servir de fundamento para a flexibilização absoluta dos contratos de trabalho, é irrecusável a prevalência das disposições insertas em acordo coletivo ou convenção coletiva de trabalho que estipulem, para o sistema de turnos ininterruptos de revezamento, jornada superior a seis horas, sem, entretanto, ultrapassar o limite diário de oito horas ou mensal de quarenta e quatro horas. 3. Há que se admitir como excludente do direito ao pagamento como extras das horas excedentes à sexta diária a expressa previsão normativa de fixação de jornada de oito horas e desde que observado esse limite e o de quarenta e quatro horas semanais. Do contrário, estar-se-ia negando vigência ao texto constitucional inscrito no 
art. $7^{\circ}$, inc. XIV, no que excepciona a jornada de seis horas na hipótese de negociação coletiva, sem cogitar de qualquer compensação. 4. O Tribunal Pleno, apreciando o Incidente de Uniformização de Jurisprudência nos autos do processo TST-ERR-576.619/1999.9, fixou o entendimento segundo o qual - uma vez estabelecida jornada superior a seis horas por meio de regular negociação coletiva, os empregados submetidos a turnos ininterruptos de revezamento não têm direito ao pagamento das sétima e oitava horas como extras -. Essa decisão vincula os órgãos fracionários do Tribunal Superior do Trabalho, por força do princípio que justifica a disciplina judiciária. 5. Recurso de Embargos de que se conhece e a que se dá provimento." (Processo: E-RR - 792079-03.2001.5.15.5555 Data de Julgamento: 11/09/2006, Relator Ministro: João Batista Brito Pereira, Subseção I Especializada em Dissídios Individuais, Data de Publicação: DJ 22/09/2006).

"TURNO ININTERRUPTO DE REVEZAMENTO. ACORDOS COLETIVOS APÓS 1\%/6/1998. HORAS EXTRAS. INTELIGÊNCIA DA SÚMULA 423 DO TST. PRONUNCIAMENTO DO PLENO DO TST SOBRE O SENTIDO E ALCANCE DO ARTIGO $7^{\circ}$, XIV, DA CONSTITUIÇÃO FEDERAL. I - Extrai-se o entendimento da Turma Regional de não ser válido o acordo coletivo, por não ter havido nenhum acréscimo salarial à jornada de oito horas diárias e quarenta e quatro semanais em regime de turnos ininterruptos de revezamento, de forma que significasse reciprocidade na negociação. Também se depreende da decisão recorrida ser incontroverso que o elastecimento da jornada de seis horas se deu mediante negociação coletiva, sem nenhum registro fático de que ela não tenha sido ultimada de forma regular e legítima. II - O Tribunal Pleno do TST, chamado a emitir tese sobre o alcance e sentido do artigo $7^{\circ}$, inciso XIV, da Constituição e da então Orientação Jurisprudencial $n^{\circ} 169$ da SBDI-1, nos autos do Processo $n^{\circ}$ TST-E-RR-576.619/1999.9, fê-lo no sentido de que "uma vez estabelecida jornada superior a 6 (seis) horas por meio de regular negociação coletiva, os empregados submetidos a turnos ininterruptos de revezamento não têm direito ao pagamento das $7^{\mathrm{a}}$ e $8^{\mathrm{a}}$ horas como extras." III - Tanto que após foi editada a Súmula 423 do TST, por meio da Resolução 139/2006, em que se consolidou o entendimento de que "Estabelecida jornada superior a seis horas e limitada a oito horas por meio de regular negociação coletiva, os empregados submetidos a turnos ininterruptos de revezamento não têm direito ao pagamento das $7^{\mathrm{a}}$ e $8^{\mathrm{a}}$ horas como extras". IV - Na oportunidade, ao se posicionar contrário à tese de que a negociação coletiva, contemplada na norma coletiva e repisada na então Orientação Jurisprudencial no 169 da SBDI-1, visava à 
introdução ou do regime de compensação ou do regime de prorrogação do horário, este magistrado permitiu-se veicular a tese de que o artigo $7^{\circ}$, inciso XIV, da Constituição não previu a hipótese de elastecimento da jornada reduzida que o devesse ser mediante a adoção de um daqueles regimes de trabalho. V - Ao contrário, lá pretendeu o constituinte permitir, mediante negociação coletiva, a transposição da jornada reduzida em relação à qual é juridicamente inexigível haja acertamento sobre o regime de compensação ou o de prorrogação, visto que nessa circunstância, de transposição de uma jornada para outra, não há que se cogitar desses regimes por inexistência de horas extras. VI- Ainda na ocasião, acrescentou este magistrado o alerta de que a negociação coletiva, em que tenha sido pactuada a transposição da jornada, há de observar aspectos formais e materiais, como, por exemplo, o mínimo de comutatividade que compense a categoria profissional pela aludida transposição, a fim de evitar que mera exibição de acordo coletivo ou de convenção, em que ela tenha sido ajustada sem observância dos requisitos formais e materiais, the dê regularidade e legitimidade, sem que o Judiciário possa sequer verificar a sua presença ou não. VII - Tendo em conta a tese emitida pelo Pleno de que a Orientação Jurisprudencial $n^{\circ} 169$ da SBDI-1 (atual Súmula 423 do TST) previu modalidade de transposição de jornada de trabalho, mediante negociação coletiva regular, fato incontroverso no caso concreto, não se há cogitar de horas extras, tendo a decisão recorrida contrariado o disposto no verbete. VIII - Não se mostra sustentável o aspecto veiculado pela Turma Regional, no exame da reciprocidade da negociação, de ser necessário o acréscimo salarial como condição compensatória para o reconhecimento dos acordos coletivos sobre a transposição da jornada reduzida. Isso porque, pelo prisma da teoria do conglobamento, presume-se que as concessões recíprocas derivam do acordo coletivo como um todo, abordado em seu conjunto, e não pelo foco particular de cada matéria - no caso, a transposição da jornada reduzida tratada no acordo coletivo. Precedente. IX - Recurso provido." (Processo: ED-RR - 248900-48.2002.5.02.0432 Data de Julgamento: 26/09/2007, Relator Ministro: Antônio José de Barros Levenhagen, $4^{\text {a }}$ Turma, Data de Publicação: DJ 11/10/2007).

Registra-se, por fim, que, de acordo com o entendimento da SBDI-1 desta Corte, é válido o acordo coletivo que elastece a jornada de trabalho dos empregados sujeitos ao regime de turnos ininterruptos de revezamentos, mesmo sem a pactuação de qualquer contraprestação em favor dos trabalhadores. 
No caso, o elastecimento da jornada de trabalho está fundamentada em norma coletiva. Desse modo, incide ao caso o teor da súmula n 423 do Tribunal Superior do Trabalho, não havendo cogitar de conflito com a Orientação Jurisprudencial n॰360 da SDI-1, como pretende o reclamante, ora recorrente.

Diante disso, não conheço do recurso de revista.

\section{ISTO POSTO}

ACORDAM os Ministros da Segunda Turma do Tribunal Superior do Trabalho, por unanimidade, não conhecer do recurso de revista.

Brasília, 25 de abril de 2012. 


\title{
ANEXO II
}

A C Ó $R$ D $\tilde{A} O$ 2 a Turma GMJRP/ir

\begin{abstract}
TURNO
ININTERRUPTO

DE

REVEZAMENTO . HORAS EXTRAS . ELASTECIMENTO DA JORNADA POR ACORDO COLETIVO. VALIDADE.

Nos termos da Súmula n 423 desta Corte, "estabelecida jornada superior a seis horas e limitada a oito horas por meio de regular negociação coletiva, os empregados submetidos a turnos ininterruptos de revezamento não têm direito ao pagamento da $7^{\mathrm{a}}$ e $8^{\mathrm{a}}$ horas como extra". E, de acordo com o entendimento da SBDI-1 desta Corte, é válido o acordo coletivo que elastece a jornada de trabalho dos empregados sujeitos ao regime de turnos ininterruptos de revezamentos, mesmo sem a pactuação de qualquer contraprestação em favor dos trabalhadores.

Recurso de revista conhecido e provido.

CORREÇÃO MONETÁRIA. ÉPOCA PRÓPRIA. SÚMULA № 381 DO TST.
\end{abstract}

Nos termos da súmula n 381 do TST, "o pagamento dos salários até o $5^{\circ}$ dia útil do mês subseqüente ao vencido não está sujeito à correção monetária. Se essa data limite for ultrapassada, incidirá o índice da correção monetária do mês subseqüente ao da prestação dos serviços, a partir do dia $1^{\circ}$ ".

Recurso de revista conhecido e provido.

Vistos, relatados e discutidos estes autos de Recurso de Revista ${ }^{\circ}$ TST-RR-116100-55.2003.5.05.0491, em 
que é Recorrente JOANES INDUSTRIAL S.A. - PRODUTOS QUímiCOS E VEGETAIS e Recorrido EDVALDO MORENO DO ESPÍRITO SANTO.

O Tribunal Regional do Trabalho da $5^{\text {a }}$ Região, mediante acórdão de fls. 156-164, complementado pelo acórdão de fls. 177-180, deu provimento ao recurso ordinário interposto pelo reclamante para deferir-lhe o pagamento de horas extras excedentes da $6^{a}$ diária.

Inconformada, a reclamada interpôs recurso de revista, às fls. 185-197, o qual foi provido, às fls. 209213, para, reconhecida a nulidade do acórdão regional, por negativa de prestação jurisdicional, determinar o retorno dos autos ao Tribunal de origem para sanar a omissão existente.

o Tribunal Regional do Trabalho, atendendo a determinação desta Turma, proferiu nova decisão, às fls. $219-227$.

Ainda inconformada, a reclamada interpõe novo recurso de revista, às fls. 230-238, com fundamento no artigo 896 da CLT.

A revista foi admitida por meio do despacho exarado às fls. 240 e 241 .

Não foram apresentadas contrarrazões, conforme certificado à fl. 243.

Não houve remessa dos autos ao Ministério Público do Trabalho ante o disposto no artigo 83 do Regimento Interno do Tribunal Superior do Trabalho.

É o relatório.

$\mathrm{V} O \mathrm{~T} O$

1. TURNO ININTERRUPTO DE REVEZAMENTO. ALTERAÇÃO DA JORNADA DE TRABALHO. HORAS EXTRAS

\section{I - CONHECIMENTO}

- Tribunal Regional do Trabalho da $5^{\text {a }}$ Região, mediante acórdão de fls. 156-164, deu provimento ao 


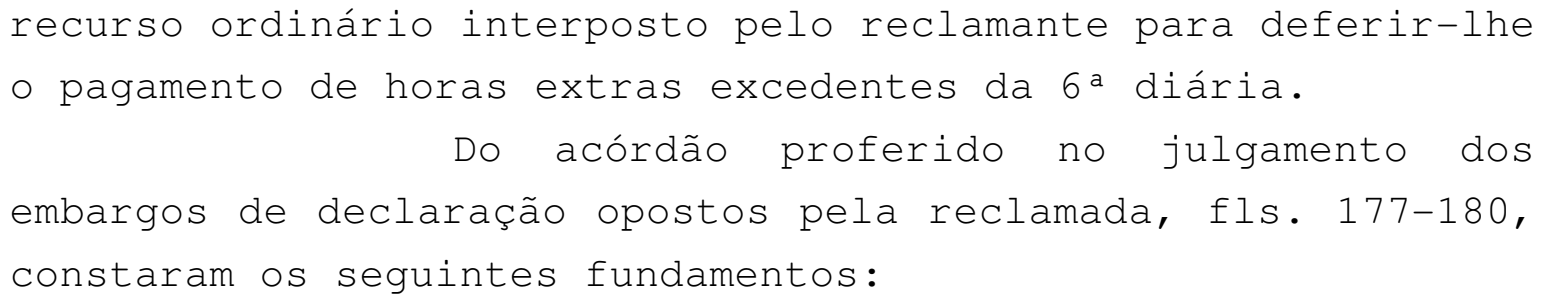

“Aduz o Embargante que o acórdão impugnado foi omisso, porque não considerou diversos elementos existentes nos autos e apontados na defesa que sinalizam para a existência da contraprestação financeira correspondente ao aumento de jornada em regime de turnos ininterruptos de revezamento.

As razões do Embargante, como postas, não devem prosperar, precisamente porque suprir a suposta "omissão" apontada implica, na verdade, em reapreciar questões de fato relativa à controvérsia instalada nos autos, ou, nas palavras do próprio Embargante, valorar novamente a modalidade compensatória e seus aspectos, o que não é possível por meio do recurso manejado.

No que tange, todavia, aos requerimentos cautelares, a decisão vergastada encerra mesmo o vício de omissão, haja vista que, embora formulados nas contra-razões (fls. 123/124), não foram apreciados.

Quanto à variação salarial, dedução, exclusão dos dias não trabalhados, descontos previdenciários e fiscais e a prescrição qüinqüenal, a pretensão do Recorrente merece acolhida, a fim que se impeça o enriquecimento ilícito do Recorrido.

No tocante à correção monetária, todavia, entendo que os índices aplicáveis são o do mês da prestação do serviço, haja vista que o Empregador, ao efetuar o pagamento dos salários no mês em que o labor fora prestado, como no caso vertente, criou condição mais favorável ao Empregado, esta que aderiu ao contrato de trabalho, impossibilitando o restabelecimento da data prevista no art. $459, \S 1^{\circ}$, da CLT.

Considerando ainda que, no caso dos autos, não se cuida de invalidação de acordo de compensação de jornada em decorrência do seu descumprimento, mas de reconhecimento da sua invalidade, não cabe a aplicação do Enunciado n. 85 do TST. 
Por fim, insta salientar que, a fim de prequestionar os dispositivos apontados pelo Embargante, não houve qualquer violação aos incisos XIII, XIV e XXVI do artigo $7^{\circ}$ da Constituição Federal, haja vista que sua interpretação deve ser sistemática, razão pela qual não se pode admitir, como ficou expressamente consignado na decisão embargada, que a autoridade dos acordos ou convenções normativas prevista nos incisos XIII e XXVI do art. $7^{\circ}$ se sobreponha à garantia constitucional prevista no inciso XIV do mesmo dispositivo, "que procurou amparar, com jornada menor, aqueles trabalhadores que, comprometidos no seu relógio biológico e incapazes de estabelecer rotina de vida no seio social (com a família e amigos), laboram em horários incertos e variáveis, em turnos que se revezam" ( $f 1.158$ ).

Inconformada, a reclamada interpôs recurso de revista, às fls. 185-197, o qual foi provido, às fls. 209213, para, reconhecida a nulidade do acórdão regional por negativa de prestação jurisdicional, determinar o retorno dos autos ao Tribunal de origem para sanar a omissão existente no tocante ao fato alegado pela reclamada de existência de compensação financeira pelo aumento da jornada de trabalho em turnos de revezamento.

O Tribunal Regional do Trabalho, atendendo a determinação desta Turma, proferiu nova decisão às fls. 219-227, nos seguintes termos:

"Ademais, as alegações do Embargante no que diz respeito à existência de compensação financeira decorrente do ajuste para ampliação da jornada de trabalho do Reclamante beira a litigância de má-fé. Se não, vejamos.

Insta observar que nos autos não subsiste qualquer elemento a validar as alegações de que o Obreiro laborava 06 (seis) dias em jornadas de 07 (sete) horas, em regime de turnos ininterruptos de revezamento, usufruindo de 02 (dois) dias de descanso, seja porque os instrumentos adunados apenas prevêem 01 folga semanal (v. fls. 58/71), seja porque os controles de 
ponto colacionados revelam que o Obreiro, efetivamente, usufruía, quando muito, de um descanso semanal.

Nesse sentido, observe-se que no mês março de 1999 (v. fl. 53) o Acionante foi instado a laborar durante 13 (treze) dias seguidos sem usufruir do descanso semanal.

Vê-se, pois, nitidamente, que não há como prevalecer a tese da Reclamada de que, conquanto trabalhasse apenas 165 horas (v. fl. 15), o Demandante recebia remuneração equivalente a 220 horas trabalhadas.

Não fosse isso, impende esclarecer que, ainda que fossem verídicas as alegações da Demandada no que diz respeito ao número de horas efetivamente trabalhadas pelo Reclamante, ainda assim não poderiam prevalecer as irresignações lançadas nos Embargos manejados.

Primeiro porque, em se tratando de empregado mensalista, o salário pago não remunera apenas as horas efetivamente trabalhadas, mas também aquelas relativas ao repouso. Veja-se, nesse sentido, que os empregados jungidos ao regime de 44 horas semanais, conquanto laborem, efetivamente, em média, 188 horas $(44 * 4,28)$, percebem o equivalente a 220 , sendo a diferença o correspondente ao descanso remunerado.

Assim, dúvidas não tenho de que o acréscimo de jornada impingido ao Obreiro, diversamente do quanto expendido nas razões dos Embargos, não foi seguido de qualquer compensação financeira para o Obreiro, como consta nas razões do decisum hostilizado.

No que concerne ao prequestionamento, entendo que este, em sentido técnico-jurídico, consiste na provocação dirigida ao Juízo prolator da decisão contra a qual se pretende interpor recurso de natureza extraordinária para que se manifeste sobre tese jurídica que, apesar de ter sido submetida ao recurso principal, não foi efetivamente examinada.

Dessa forma, a Súmula $\mathrm{n}^{\circ} 297$, do C. TST não autorizou a parte, por esse meio e a esse título, rediscutir matérias decididas com suficiente clareza pelo Juízo ad quem, como tenta fazer a Embargante, uma vez que questiona matéria que já foi devidamente apreciada por esta Relatoria, pretendendo, em verdade, o seu reexame. 
Valentin Carrion, em sua Obra intitulada "Comentários à Consolidação das Leis do Trabalho", 27ª edição, 2002, pág. 749, ensina que somente é necessário o prequestionamento para fins de interposição de recurso de revista quando a Turma não tenha adotado, explicitamente, tese acerca das matérias abordadas no Apelo interposto, se não vejamos:

"O prequestionamento dos fundamentos ensejadores do recurso de revista é requisito para seu conhecimento; esse prequestionamento ocorre quando a questão foi levantada e rejeitada; se não o foi expressamente, exige-se que se tenha interposto embargos declaratórios (Súmula 297 do TST)”.

No que tange, todavia, aos requerimentos cautelares, a decisão vergastada encerra mesmo o vício de omissão, haja vista que, embora formulados nas contra-razões (fls. 123/124), não foram apreciados.

Quanto à variação salarial, dedução, exclusão dos dias não trabalhados, descontos previdenciários e fiscais e a prescrição qüinqüenal, a pretensão do Recorrente merece acolhida, a fim que se impeça o enriquecimento ilícito do Recorrido.

No tocante à correção monetária, todavia, entendo que os índices aplicáveis são o do mês da prestação do serviço, haja vista que o Empregador, ao efetuar o pagamento dos salários no mês em que o labor fora prestado, como no caso vertente, criou condição mais favorável ao Empregado, que aderiu ao contrato de trabalho e impossibilita o restabelecimento da data prevista no art. $459, \S 1^{\circ}$, da CLT.

Considerando ainda que, no caso dos autos, não se cuida de invalidação de acordo de compensação de jornada em decorrência do seu descumprimento, mas de reconhecimento da sua invalidade, não cabe a aplicação da Súmula n. 85 do TST.

Por fim, insta salientar que, a fim de prequestionar os dispositivos apontados pelo Embargante, não houve qualquer violação aos incisos XIII, XIV e XXVI do artigo $7^{\circ}$ da Constituição Federal, haja vista que sua interpretação deve ser sistemática, pelo que não se pode admitir, como ficou expressamente consignado na decisão embargada, que a autoridade dos acordos ou convenções normativas prevista nos incisos XIII e XXVI do art. $7^{\circ}$ se sobreponha à garantia 
constitucional prevista no inciso XIV do mesmo dispositivo, "que procurou amparar, com jornada menor, aqueles trabalhadores que, comprometidos no seu relógio biológico e incapazes de estabelecer rotina de vida no seio social (com a família e amigos), laboram em horários incertos e variáveis, em turnos que se revezam” (fl. 158)" (grifou-se).

Ainda inconformada, a reclamada interpõe recurso de revista, às fls. 230-238, insistindo na tese de que a majoração na jornada de trabalho do reclamante foi devidamente compensada financeiramente. Não obstante, sustenta não ser necessária a compensação financeira das horas que excederam a jornada de seis horas, uma vez que a modificação da jornada de trabalho do reclamante decorreu de negociação coletiva intermediada por sindicato da categoria. Aduz que não existe exigência legal para a compensação e que a decisão regional contraria a súmula n 423 do TST.

Eventualmente, caso mantida a condenação ao pagamento de horas extras, requer o retorno ao status quo para se determinar que no exame das horas extras sejam abatidas a folga conferida ao reclamante e os valores pagos a maior, a título de horas laboradas, sob pena de se configurar bis in idem e enriquecimento sem causa, em observância ao disposto no artigo 182 do Código Civil.

Indica violação dos artigos $5^{\circ}$, inciso II, 70, incisos XIV e XXVI, e $8^{\circ}$, inciso VI, da Constituição Federal e 182 do Código Civil. Invoca contrariedade à Súmula n॰ 423 do TST e colaciona arestos em apoio à sua tese.

o recurso de revista alcança conhecimento na divergência jurisprudencial demonstrada por meio dos arestos de fls. 234 e 235, oriundos da SBDI-1 desta corte, os quais consignam tese no sentido de que o elastecimento da jornada de trabalho por intermédio de negociação coletiva é válido e não gera direito ao pagamento de horas extras excedentes da sexta diária.

Conheço do recurso por divergência jurisprudencial. 


\section{II - MÉRITO}

A Constituição Federal de 1988, ao mesmo tempo em que se preocupou em proteger os trabalhadores, estabelecendo limites para a jornada de trabalho em turnos ininterruptos de revezamentos, ressalvou o valor e o prestígio que os sindicatos e as negociações coletivas ganharam na sociedade e, consequentemente, no Direito do Trabalho atual, facultando às partes interessadas o ajuste de jornada diversa para a hipótese.

A par da norma específica que trata do tema, artigo 70, inciso XIV, da Carta Magna, o mesmo artigo, no inciso XXVI, assegura o reconhecimento das negociações coletivas, buscando a validação e o revigoramento da atuação sindical. No artigo $8^{\circ}$, inciso III, do mesmo Texto Constitucional, observa-se, ainda, clara a missão do sindicato de defender os interesses individuais e coletivos da categoria que representar.

Consoante o disposto no artigo $7^{\circ}$, inciso XIV, da Constituição da República, os empregados submetidos ao turno ininterrupto de revezamento terão jornada de trabalho de seis horas diárias, salvo negociação coletiva.

$$
\text { De outro lado, esta corte firmou }
$$

entendimento de que, uma vez estabelecida jornada superior a seis horas e limitada a oito horas, mediante regular negociação coletiva, os empregados submetidos a turnos ininterruptos de revezamento não têm direito ao pagamento das $7^{a}$ e $8^{a}$ horas como extras.

É O que se extrai da Súmula nº 423 desta Corte, que assim dispõe:

“TURNO ININTERRUPTO DE REVEZAMENTO. FIXAÇÃO DE JORNADA DE TRABALHO MEDIANTE NEGOCIAÇÃO COLETIVA. VALIDADE. (conversão da Orientação Jurisprudencial no 169 da SDI-I, Res. 139/06 - DJ 10.10.06)

Estabelecida jornada superior a seis horas e limitada a oito horas por meio de regular negociação coletiva, os empregados 
submetidos a turnos ininterruptos de revezamento não têm direito ao pagamento da $7^{\mathrm{a}}$ e $8^{\mathrm{a}}$ horas como extra".

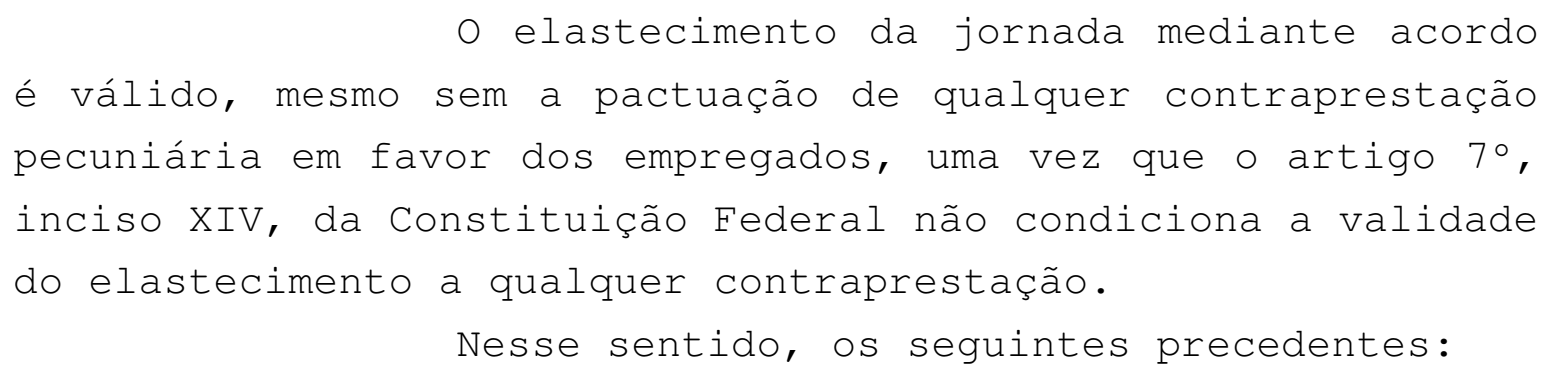

"RECURSO DE REVISTA. TURNO ININTERRUPTO DE REVEZAMENTO. HORAS EXTRAS. ELASTECIMENTO DA JORNADA. NORMA COLETIVA. VALIDADE. SÚMULA 423 DO TST. O Tribunal Regional adotou tese no sentido de que, mesmo diante de norma coletiva, a prorrogação de jornada em turnos ininterruptos acarreta o direito do trabalhador ao pagamento de sétima e oitava horas como extras, visto que não teria havido qualquer compensação pecuniária aos empregados. Por seu turno, o entendimento posto na Súmula 423 desta Corte é no sentido de que estabelecida jornada superior a seis horas e limitada a oito horas por meio de regular negociação coletiva, os empregados submetidos a turnos ininterruptos de revezamento não tem direito ao pagamento da $7^{\mathrm{a}}$ e $8^{\mathrm{a}}$ horas como extras. Ressalta-se, ainda, que, ao contrário do que concluiu o Tribunal a quo, o acordo é válido mesmo sem a pactuação de qualquer contraprestação pecuniária em favor dos empregados. Precedentes. Conhecido e provido." (RR129800-53.2008.5.15.0036, Relator Ministro Emmanoel Pereira, 5a Turma, DEJT $28 / 10 / 2010)$.

"RECURSO DE REVISTA DA RECLAMADA. HORAS EXTRAS APÓS A $6^{\mathrm{a}}$ DIÁRIA. TURNOS DE REVEZAMENTO. ACORDO COLETIVO DE TRABALHO. I - O Tribunal Pleno do TST, chamado a emitir tese sobre o alcance e sentido do artigo $7^{\circ}$, inciso XIV, da Constituição e da então Orientação Jurisprudencial no 169 da SBDI-1, nos autos do Processo ${ }^{\circ}$ TST-E-RR-576.619/1999.9, fê-lo no sentido de 
que "uma vez estabelecida jornada superior a 6 (seis) horas por meio de regular negociação coletiva, os empregados submetidos a turnos ininterruptos de revezamento não têm direito ao pagamento das $7^{\mathrm{a}}$ e $8^{\mathrm{a}}$ horas como extras". II - Tanto que, após, foi editada a Súmula $n^{\circ} 423$ do TST, por meio da Resolução $n^{\circ}$ 139/2006, pela qual se consolidou o entendimento de que "Estabelecida jornada superior a seis horas e limitada a oito horas por meio de regular negociação coletiva, os empregados submetidos a turnos ininterruptos de revezamento não têm direito ao pagamento das $7^{\mathrm{a}}$ e $8^{\mathrm{a}}$ horas como extras". III - Pela tese emitida pelo Pleno de que a Orientação Jurisprudencial $n^{\circ}$ 169 da SBDI-1 (atual Súmula $\mathrm{n}^{\circ} 423$ do TST) previu modalidade de transposição de jornada de trabalho, mediante negociação coletiva regular, fato incontroverso no caso concreto, não se há cogitar de horas extras, tendo a decisão recorrida contrariado o disposto no verbete. IV - Não se mostra sustentável o aspecto veiculado pela Turma Regional, no exame da reciprocidade da negociação, de ser necessária concessão de "contrapartida direta em razão do elastecimento da jornada de trabalho preconizada no art. $7^{\circ}$, XIV da Constituição". Isso porque, pelo prisma da teoria do conglobamento, presume-se que as concessões recíprocas derivam do acordo coletivo como um todo, e não pelo foco particular de cada matéria - no caso, a transposição da jornada de seis para a jornada de oito horas, objeto de negociação coletiva. Nesse sentido, precedentes deste Tribunal. IX - Recurso provido. (...)." (RR-4620053.2006.5.15.0021, Relator Ministro Antônio José de Barros Levenhagen, $4^{\text {a }}$ Turma, DEJT $15 / 10 / 2010)$.

"RECURSO DE REVISTA. HORAS EXTRAS. TURNO ININTERRUPTO DE REVEZAMENTO. ELASTECIMENTO DA JORNADA DE TRABALHO. NEGOCIAÇÃO COLETIVA. AUSÊNCIA DE VANTAGEM PARA O EMPREGADO. VALIDADE. TEORIA DO CONGLOBAMENTO. Consoante firmado na Súmula 423 do TST, estabelecida jornada superior a seis horas e limitada a oito horas por meio de regular negociação coletiva, os empregados 
submetidos a turnos ininterruptos de revezamento não têm direito ao pagamento da $7^{\mathrm{a}}$ e $8^{\mathrm{a}}$ horas como extras. Na hipótese, o Tribunal Regional entendeu que, apesar de haver norma coletiva nesse sentido, não haveria como lhe conferir validade, porquanto não houve nenhuma contraprestação ao empregado pelo elastecimento da jornada de trabalho. $\underline{\mathrm{O} \text { entendimento desta }}$ Turma é no sentido de que não há como considerar inválida norma coletiva que elasteceu a jornada de trabalho para os empregados que laboram em regime de turno ininterrupto de revezamento, ainda que não lhes tenha sido auferida nenhuma vantagem compensatória. Isso se deve porque, em face da Teoria do Conglobamento, o que deve ser analisado é se o conjunto das cláusulas do acordo ou da convenção coletiva é, ou não, benéfica ao trabalhador. Nesse contexto, merece reforma a decisão regional, a fim de excluir da condenação o pagamento, como hora extra, do tempo excedente à $6^{a}$ hora diária, quando o trabalho ocorreu em turnos ininterruptos de revezamento. Recurso de revista de que se conhece e a que se dá provimento." (RR-19200-92.2004.5.15.0039, Relator

Ministro Pedro Paulo Manus, DEJT $10 / 09 / 2010)$.

"AGRAVO. TURNO ININTERRUPTO DE REVEZAMENTO. JORNADA DE OITO HORAS PREVISTA EM NORMA COLETIVA. EFEITOS. A respeito da possibilidade de elastecimento da jornada desenvolvida em turnos ininterruptos de revezamento de seis para oito horas, por meio de norma coletiva, o c. TST já sedimentou entendimento, em sentido positivo, conforme Súmula 423/TST. Destaque-se que a expressão -regular negociação- prevista nessa diretriz jurisprudencial diz respeito a aspecto formal na elaboração do ajuste, nada tendo a ver com o conteúdo material. Assim, não havendo outra exceção à validade da cláusula normativa, a qual não restou comprovada, correta a e. Turma ao decidir com base na Súmula 423/TST. E como já registrado no v. acórdão recorrido, a jurisprudência desta e. Subseção firmou-se também no sentido de que o acordo é válido, ainda que os trabalhadores não tenham nenhum benefício em contrapartida. Recurso de 
agravo a que se nega provimento." ( $A G-E-E D-R R-182600-$ 13.2002.5.15.0022, Relator Ministro: Horácio Raymundo de Senna Pires, Subseção I Especializada em Dissídios Individuais, Data de Publicação: 09/04/2010).

"RECURSO DE EMBARGOS INTERPOSTO ANTERIORMENTE À VIGÊNCIA DA LEI N. ${ }^{\circ}$ 11.496/2007. TURNOS ININTERRUPTOS DE REVEZAMENTO ELASTECIMENTO DA JORNADA DE TRABALHO POR MEIO DE ACORDO COLETIVO. EFICÁCIA DO ACORDO COLETIVO MESMO SEM A PACTUAÇÃO DE QUALQUER CONTRAPRESTAÇÃO. INDEVIDO O PAGAMENTO DAS 7. ${ }^{a}$ E $8 .^{a}$ HORAS COMO EXTRAORDINÁRIAS. SÚMULA N. ${ }^{\circ} 423$ DO TST. 1. O art. 7. ${ }^{\circ}$ XIV, da Constituição Federal de 1988 estabelece jornada de seis horas para o trabalho realizado em turnos ininterruptos de revezamento, mas permite que a empresa fixe jornada superior a seis horas mediante negociação coletiva. 2. Ressalte-se que o acordo coletivo celebrado entre as partes tem força de lei, devendo por isso ser respeitado, conforme o disposto no art. 7., XXVI, da Carta Magna. 3. Dessarte, existindo acordo coletivo no sentido de estabelecer a jornada de 8 (oito) horas para trabalho realizado em turno ininterrupto de revezamento, não há de se falar em pagamento das 7. ${ }^{\mathrm{a}}$ e $8 .^{\mathrm{a}}$ horas como extraordinárias, pois, se assim não fosse, não haveria razão de ser da ressalva feita no inciso XIV do art. 7. ${ }^{\circ}$ da Carta Magna. 4. Registre-se, por fim, que, de acordo com o entendimento da SBDI-1 desta Corte, é válido o acordo coletivo que elastece a jornada de trabalho dos empregados sujeitos ao regime de turnos ininterruptos de revezamento, mesmo sem a pactuação de qualquer contraprestação em favor dos trabalhadores. Recurso de Embargos conhecido em parte e provido." (Processo: EED-RR - 147000-07.2001.5.15.0105 Data de Julgamento: 27/11/2008, Relatora Ministra: Maria de Assis Calsing, Subseção I Especializada em Dissídios Individuais, DEJT 19/12/2008). 
Assim, de acordo com o entendimento da SBDI-1 desta corte, é válido o acordo coletivo que elastece a jornada de trabalho dos empregados sujeitos ao regime de turnos ininterruptos de revezamentos, mesmo sem a pactuação de qualquer contraprestação em favor dos trabalhadores.

Dessa forma, a decisão regional, pela qual se deferiu ao reclamante 0 pagamento de horas extras excedentes da sexta diária, não se coaduna com o entendimento sedimentado nesta corte.

Com esses fundamentos, dou provimento ao recurso de revista para restabelecer a sentença de fls. 8991, por meio da qual se julgou improcedente o pedido de pagamento de horas extras excedentes da sexta diária.

2. CORREÇÃO MONETÁRIA. ÉPOCA PRÓPRIA.

SÚMULA No 381 DO TST

\section{I - CONHECIMENTO}

- Regional entendeu que a correção monetária deve ser feita com base nos índices correspondentes ao mês da prestação dos serviços, ao fundamento de que "o Empregador ao efetuar o pagamento dos salários no mês em que o labor fora prestado, como no caso vertente, criou condição mais favorável ao Empregado, que aderiu ao contrato de trabalho e impossibilita o restabelecimento da data prevista no artigo $459, \S 1^{\circ}$, da CLT".

A reclamada defende que a correção monetária seja feita com base nos índices correspondentes ao mês seguinte ao da prestação dos serviços, nos termos da Súmula n॰381 e da Orientação Jurisprudencial n॰ 124 da SBDI1 ambas do TST, que tem por contrariadas. 


\section{Com razão.}

Dispõe o parágrafo único do artigo 459 da CLT que, se o pagamento do salário foi estipulado por mês, deverá ser efetuado, o mais tardar, até o quinto dia útil do mês subsequente ao vencido.

- legislador estabeleceu, assim, uma data limite para o pagamento dos salários mensais. Ultrapassado esse limite, deverá o débito trabalhista ser corrigido conforme a determinação prevista no artigo 39 da Lei no $8.177 / 91$.

$\mathrm{Na}$ interpretação desse dispositivo legal, este Tribunal Superior consolidou seu entendimento a respeito da matéria, nos termos da súmula n³81, cujo teor é o seguinte:

“CORREÇÃO MONETÁRIA. SALÁRIO. ART. 459 DA CLT. (conversão da Orientação Jurisprudencial no 124 da SDI1) - Res. 129/2005 - DJ 20.04.05. O pagamento dos salários até o $5^{\circ}$ dia útil do mês subseqüente ao vencido não está sujeito a correção monetária. Se essa data for ultrapassada, incidirá o índice de correção monetária do mês subseqüente ao da prestação dos serviços, a partir do dia $1^{\circ}$. (ex-OJ n $^{\circ} 124$ Inserida em 20.04.1998)".

Portanto, a decisão regional contraria o citado verbete sumular.

Assim, conheço do recurso de revista por contrariedade à Súmula $\mathrm{n}^{\circ} 381$ do TST.

\section{II - MÉRITO}

Conhecido o recurso de revista por contrariedade ao entendimento sumulado nesta Corte, impõe-se o seu provimento.

Dessa forma, dou provimento ao recurso de revista para determinar que a correção monetária dos débitos trabalhistas somente incida quando não efetuado o pagamento dos salários até $05^{\circ}$ dia útil do mês posterior ao vencido, 
observando-se o índice da correção monetária do mês subsequente ao da prestação de serviços, nos moldes definidos na súmula $n^{\circ} 381$ do TST.

\section{ISTO POSTO}

ACORDAM os Ministros da Segunda Turma do Tribunal Superior do Trabalho, por unanimidade, conhecer do recurso de revista por divergência jurisprudencial, quanto ao tema "Turno Ininterrupto De Revezamento. Alteração Da Jornada De Trabalho. Horas Extras" e, no mérito, dar-lhe provimento para restabelecer a sentença de fls. 89-91, por meio da qual se julgou improcedente o pedido de pagamento de horas extras excedentes da sexta diária. Por unanimidade, ainda, conhecer do recurso de revista no tocante à "Correção Monetária. Época Própria. Súmula No 381 do TST", por contrariedade à Súmula nº 381 do TST e, no mérito, dar-lhe provimento para determinar que a correção monetária dos débitos trabalhistas somente incida quando não efetuado o pagamento dos salários até 0 50 dia útil do mês posterior ao vencido, observando-se o índice da correção monetária do mês subsequente ao da prestação de serviços, nos moldes definidos na súmula n 381 do TST.

Brasilia, 25 de abril de 2012. 


\section{ANEXO III}

PODER JUDICIÁRIO

JUSTIÇA DO TRABALHO

TRIBUNAL REGIONAL DO TRABALHO DA 23를 REGIÃO

TRT - RO - 02219.2008.051.23.00-6

ORIGEM : VARA DO TRABALHO DE TANGARÁ DA SERRA

RELATOR : DESEMBARGADOR ROBERTO BENATAR

REVISOR : JUIZ CONVOCADO AGUIMAR PEIXOTO

RECORRENTE : Maria Aparecida Lopes de Sales

Advogado : Newton Zacarias Petermann Fregadolli Brandão

RECORRIDO : Moacir Sansão e Outros

Advogados : Luiz Mariano Bridi e outro(s)

\section{EMENTA}

\section{DANO MORAL. TRABALHO EM CONDIÇÕES}

DEGRADANTES. O direito à indenização por dano moral pressupõe a comprovação da conduta culposa do empregador, do dano ao empregado e do nexo causal entre o ato do empregador e o prejuízo sofrido. $O$ caso dos autos é afeto, em tese, à hipótese que repetidas vezes tem se apresentado aos pretórios trabalhistas, qual seja, exposição do trabalhador à situação degradante durante a prestação de serviços, a qual, compete registrar, é hábil em tese à caracterização de danos aos direitos da personalidade. Na hipótese, constatou-se duas irregularidades em confronto com a NR-31, quais sejam, os sanitários, embora limpos e em locais de difícil acesso, não eram separados por sexo, bem assim que não havia local adequado para se fazer as refeições, as quais não são graves o suficiente a configurar a existência de trabalho degradante, tratandose de meras irregularidades, não sendo hábeis a provocar danos na dignidade do ser humano.

Vistos, relatados e discutidos os presentes autos, em que são partes as acima indicadas.

\section{RELATÓRIO}

A MM. ․ Juíza Deizimar Mendonça Oliveira, da egrégia Vara do Trabalho de Tangará da Serra-MT, acorde com a r. sentença de fls. 523/530, cujo relatório adoto, rejeitou todos os pedidos da exordial. Concedeu, ao final, a gratuidade da justiça à reclamante. Aportou, aos autos, o recurso ordinário obreiro, às fls. 533/540, objetivando a reforma da sentença para que o réu seja condenado ao pagamento de indenização por dano moral por trabalho em situação degradante. Contrarrazões ao recurso ofertadas e incrustadas às fls. 545/551. É, em síntese, o relatório. 


\section{ADMISSIBILIDADE}

Presentes os pressupostos processuais de

admissibilidade, conheço do recurso ordinário interposto, bem assim de suas contrarrazões.

\section{MÉRITO}

Insurge-se, a autora, contra a sentença que rejeitou seu

pedido de condenação dos réus ao pagamento de indenização por danos morais decorrentes de trabalho em situação degradante, aduzindo que "Fora realizada perícia técnica no processo $1580.2008-5$, ao qual fora utilizado como prova emprestada, onde no referido laudo emitido pelo inclito perito às fls. 316/351, concluiu que a Recorrente não trabalhava em condições de total conformidade com a NR-31 (fls. 341), pois as barracas sanitárias não eram divididas por sexo, e que até o ano de 2008, quando foram implantadas as mesas e cadeiras, a autora, ora Recorrente, era obrigada a realizar suas refeições no chão das propriedades da reclamada" (fl. 536). Pois bem.

A indenização por dano moral repousa na teoria subjetiva da responsabilidade civil, cujo postulado básico estriba-se no conceito de culpa, e esta, fundamentalmente, tem por pressuposto a infração de uma norma preestabelecida.

Ambas as modalidades de culpa, aquiliana e contratual, obrigam o autor a responder civilmente pelos prejuízos causados. Quanto às exigências no concernente às provas, incumbe ao prejudicado demonstrar todos os elementos originários da responsabilidade, ou seja, o dano, a infração da norma e o nexo de causalidade entre um e outra, na hipótese de tratar-se de culpa extracontratual ou aquiliana.

Com efeito, é cediço que o direito à indenização por dano moral pressupõe a comprovação da conduta culposa do empregador, do dano ao empregado e do nexo causal entre $o$ ato do empregador e 0 prejuízo sofrido.

O caso dos autos é afeto, em tese, à hipótese que repetidas vezes tem se apresentado aos pretórios trabalhistas, qual seja, exposição do trabalhador à situação degradante durante a prestação de serviços, a qual, compete registrar, é hábil em tese à caracterização de danos aos direitos da personalidade.

Colho da jurisprudência:

"DANO MORAL. CONDIÇÕES DE HIGIENE MÍNIMAS

DIGNAS E SAUDÁVEIS AO TRABALHADOR.

RESPONSABILIDADE DO EMPREGADOR. O

Constituinte visando proteger o trabalhador contra o dano à saúde ou integridade física prevista pelo art. 70, inciso XXII (redução dos riscos inerentes ao trabalho, por meio de normas de saúde, higiene e segurança), ampliou a responsabilidade patronal a fim de que seja oferecido ao trabalhador um local de trabalho sadio, um local de trabalho onde haja inclusive respeito à dignidade da pessoa humana, à sua personalidade à própria honra. Caso o empregador não cumpra com suas responsabilidades sociais, decorrentes do contrato de trabalho, responderá por seus atos, ainda que 
omissivos, pelos danos ocasionados ao empregado decorrentes de lesão à honra, dano moral (art. $5^{\circ}$, inciso $X$ da CR). Demonstrado que a Reclamada não proporcionou ao Reclamante local adequado para higiene (latrinas), equipamentos de segurança para o desempenho de suas atividades, além das condições precárias a que os empregados eram submetidos ao serem transportados até o local da prestação dos trabalhos e a ausência de local apropriado para refeição e descanso, privando-o de condições mínimas dignas e saudáveis para qualquer ser humano, comete ilícito capaz de gerar o dever de indenizar a fim de reparar o dano moral causado ao empregado. Assim, considerando-se a situação relatada nos autos, o período laborado pelo Reclamante e, ainda, a condição financeira da Reclamada, apresenta-se razoável a fixação do valor da indenização por danos morais em $R$ \$ $3.000,00$ (três mil reais), não se constituindo em meio para enriquecimento indevido, atendendo proporcionalmente aos caracteres compensatório e punitivo que norteiam a fixação do quantum indenizatório. Recurso do Reclamante parcialmente provido."

(TRT da 23르 Região - 2 ${ }^{\mathrm{a}}$ T. - RO 00462.2006.021.23.006 - Rel. Juiz Conv. Bruno Weiler - julg. 18.10.06 extraído do respectivo sítio) "(...) DANO MORAL. CONDIÇÕES DE HIGIENE, ALIMENTAÇÃO E DESCANSSO. O empregador que é o detentor do poder diretivo, regulamentar e disciplinar, deve exercê-lo nos limites da lei, buscando sempre preservar o patrimônio moral do empregado. Assim, diante de sua omissão, não proporcionando os meios e local adequados para a higiene, alimentação e descanso de seus empregados, bem como não garantindo as mínimas condições dignas e saudáveis a qualquer ser humano, o empregador comete dano moral, razão pela qual é garantido ao empregado o direito de obter sua reparação, nos termos dos artigos $5^{\circ}$, incisos $\mathrm{V}$ e X, da CF, 186 e 927 do Código Civil brasileiro".

(TRT da 23를 Região - 2 $2^{\mathrm{a}}$ Turma - RO 00513.2006.021.23.00-0 - 2 $2^{\mathrm{a}}$ T. - Rel. Des. Osmair Couto - extraído do respectivo sítio) Cumpre, pois, verificar se efetivamente fizeram-se presentes as alegadas condições degradantes de trabalho, de molde a configurar o ato ilícito empresarial ensejador do dano moral.

Analisando o laudo pericial acostado às fls. 316/351, observo que este constatou a existência de duas irregularidades em confronto com a NR-31, quais sejam, os sanitários, embora limpos e em locais de difícil acesso, não eram separados por sexo, bem assim que, na época em que a autora laborou no réu, não havia local adequado para se 
fazer as refeições, o qual só foi implantado em 2008, registrando, contudo, que os ônibus possuíam toldos para abrigar os empregados nas intempéries. Ora, tenho que tais afrontas à norma não são graves o suficiente a configurar a existência de trabalho degradante, tratando-se de meras irregularidades, não sendo hábeis a provocar danos na dignidade do ser humano.

Nesse sentido já decidiu esta Corte, nos autos do processo 00140.2009.071.23.00-6, no qual funcionei como redator designado, pedindo vênia para colher da fundamentação: "Assim, somente estas duas últimas testemunhas podem esclarecer quanto às condições de trabalho propiciadas à reclamante na Usina Jaciara. Ocorre, porém, que suas declarações cingem-se a noticiar a ausência de barracas e mesas para refeição antes de 2007/2008, fato que, isoladamente, não se me afigura de gravidade bastante à caracterização de trabalho degradante.

Com efeito, referidas testemunhas não demonstram as irregularidades mais graves denunciadas na exordial, as quais, se confirmados, importariam deveras atentado à dignidade humana inerente à pessoa da autora, como a ausência de água potável, a falta de sanitários, a contingência de fazer as necessidades no mato e sem papel higiênico etc. (fls. 09/10)

Registro que a simples ausência de mesas e tendas para as refeições deve ser encarado como um mero dissabor, o qual, não obstante constituir-se em desconformidade com as normas de higiene $e$ ergonomia do trabalho que deve ser corrigida pela reclamada, não rende ensejo a indenização por danos morais." (grifei)

Desse modo, não havendo nos autos elementos suficientes para caracterizar o labor em condições degradantes, mantenho a sentença que rejeitou o pedido de condenação do reclamado ao pagamento de indenização por danos morais.

Nego provimento.

\section{CONCLUSÃO}

Isso posto, conheço do recurso ordinário interposto e, no mérito, nego-lhe provimento, nos termos da fundamentação supra.

É como voto.

\section{ISSO POSTO:}

DECIDIU a $1^{a}$ Turma de Julgamento do Egrégio

Tribunal Regional do Trabalho da Vigésima Terceira Região, por unanimidade, conhecer do recurso ordinário interposto e, no mérito, por maioria, negar-Ihe provimento, nos termos do voto do Desembargador Relator, vencido o Juiz Revisor, que dava provimento ao recurso, o qual juntará declaração de voto

Cuiabá-MT, terça-feira, 27 de abril de 2010

ROBERTO BENATAR

Desembargador Federal do Trabalho

Relator 
Fonte: DEJT/TST no 472/2010 de 05/05/2010

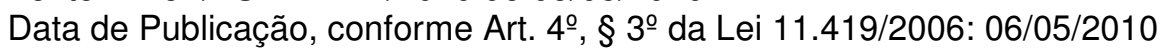


ANEXO IV

ACÓRDÃO

( $4^{\text {a }}$ Turma - $7^{\text {a }}$ Câmara)

\author{
RECURSOS ORDINÁRIOS \\ EM PROCEDIMENTO SUMARÍSSIMO
}

\author{
Processo TRT 15 ${ }^{\mathrm{a}}$ Região n⿳0 0003716-64.2010.5.15.0156 \\ $1^{\circ}$ Recorrente: RAILTON DE SOUSA SANTOS \\ $2^{\text {a }}$ Recorrente: LDC-SEV BIOENERGIA S.A. \\ Origem: VARA ITINERANTE DO TRABALHO DE MORRO AGUDO \\ Juiz sentenciante: RICARDO LUIS VALENTINI
}

TRABALHO RURAL. PRECARIEDADE DAS INSTALAÇÕES SANITÁRIAS E
REFEITÓRIOS. INEXISTÊNCIA DE DANOS MORAIS INDENIZÁVEIS.

Diante das condições rústicas inerentes ao ambiente de trabalho rural, bem como da notória dificuldade do empregador de proporcionar instalações sanitárias satisfatórias e refeitórios adequados, não emerge dano moral indenizável, em que pesem os dissabores e desconfortos sofridos pelos trabalhadores.

\title{
RELATÓRIO
}

Contra a r. sentença de fls. 220/221 que, complementada pela decisão dos embargos de declaração de fls. 225/226, julgou procedente em parte a reclamatória, recorrem ordinariamente ambas as partes.

O primeiro recorrente (reclamante), em suas razões de recurso de fls. 228/234, pugna pela majoração do valor da indenização deferida a título de danos morais.

A segunda recorrente (reclamada) recorre às fls. 235/248, arguindo a nulidade parcial da sentença recorrida e requerendo seja excluída a condenação ao pagamento de multa e 
indenização em face dos embargos de declaração indevidamente tidos por protelatórios. Insurge-se contra o pagamento de indenização por danos morais, pugnando, caso mantida a condenação, pela redução do quantum arbitrado a tal título e pela incidência de juros e correção monetária a partir da data do arbitramento.

Depósito recursal e custas às fls. 251/252.

Contrarrazões às fls. 256/260, pelo reclamante, e às fls. 261/267, pela reclamada.

O processo não foi remetido à D. Procuradoria Regional do Trabalho.

É o breve relatório.

\section{VOTO}

Conheço dos recursos ofertados, por regulares.

Tendo em vista a preliminar de nulidade arguida pela reclamada, será o apelo patronal apreciado por primeiro.

\section{I- Recurso da reclamada}

\section{1- Nulidade}

A ora recorrente suscita a nulidade parcial do julgado, alegando que, embora instado via embargos de declaração, o Juízo de origem não se manifestou acerca das omissões apontadas.

Sem razão.

Na realidade, a reclamada, insatisfeita com o quanto decidido, tenta macular o r. julgado, taxando-o de nulo. Mas não é isso o que se verifica, pois houve a devida prestação jurisdicional, tendo o Juízo a quo apreciado as provas constantes dos autos de acordo com o seu livre convencimento (artigo 131 do CPC), com exposição expressa dos motivos que o levaram a decidir pelo deferimento da indenização por danos morais. O fato de o Juízo decidir de forma contrária aos anseios da parte não configura negativa de prestação jurisdicional.

Ademais, como os alegados erros de julgamento poderão ser corrigidos nesta esfera recursal, a parte não será prejudicada e, consoante as disposições expressas do Texto Consolidado, para que se reconheça a nulidade processual é necessário que 
advenha prejuízo aos litigantes (artigo 794) e que não se possa suprir a falta ou repetir o ato (artigo 796, “a”). Esta não é a hipótese vertente.

Rejeito, pois, a preliminar de nulidade arguida.

\section{2- Multa e indenização na decisão de embargos declaratórios}

A reclamada requer seja excluída a condenação ao pagamento de multa e indenização em face dos embargos de declaração indevidamente tidos por protelatórios, sustentando que em nenhum momento teve intenção de procrastinar o feito ou agir com má-fé.

O Juízo de origem entendeu que os embargos de declaração opostos pela reclamada tinham cunho meramente protelatório e declarou-a litigante de má-fé, condenando-a ao pagamento de multa de $1 \%$ sobre o valor atribuído à causa e indenização de $20 \%$ do valor da causa (fls. 225/226).

Merece parcial reforma o decidido.

Não houve qualquer "omissão", "contradição" ou "obscuridade" na r. sentença recorrida que justificasse o uso da via declaratória pela parte. A oposição de embargos de declaração sem nexo com os permissivos legais para a utilização do referido remédio processual levou à imposição da multa de $1 \%$ sobre o valor da causa, conforme previsão contida no parágrafo único, do artigo 538 do CPC, eis que referido dispositivo diz respeito, exatamente, à coibição dos embargos de declaração manejados de forma protelatória.

Contudo, não há razão para a aplicação também da indenização de $20 \%$ sobre o valor da causa por litigância de má-fé, nos termos do parágrafo $2^{\circ}$ e caput do artigo 18 do CPC, até porque descabe a imputação de dupla penalidade em decorrência do mesmo ato.

Portanto, provejo parcialmente o apelo para excluir da condenação o pagamento da indenização de $20 \%$ sobre o valor da causa, por litigância de má-fé, arbitrada pela decisão de fls. 225/226.

Diante da identidade de matéria, analisarei conjuntamente os apelos com relação à questão da indenização por danos morais.

\section{Indenização por danos morais / Valor}

O reclamante pugna pela majoração do valor da indenização deferida a título de danos 
morais.

A reclamada, por sua vez, assevera que não pode subsistir a indenização por danos morais, porque não comprovada a existência de ato ilícito ou a culpa patronal, sendo que eventuais condições precárias de higiene também decorreriam de culpa concorrente dos trabalhadores. Caso mantida a condenação, pede a redução do valor fixado a tal título, à luz da razoabilidade e da proporcionalidade.

O Juízo a quo entendeu que o autor foi exposto a situações degradantes de trabalho porque a empregadora não fornecia com a habitualidade devida as instalações sanitárias necessárias, nem tampouco disponibilizava locais apropriados e suficientes para que os trabalhadores realizassem suas refeições, e condenou a reclamada a pagar ao reclamante $\mathrm{R} \$ 5.000,00$ a título de indenização por danos morais.

Merece reforma o decidido.

Dano moral, como leciona VALENTIN CARRION, "é o que atinge os direitos da personalidade, sem valor econômico, tal como a dor mental psíquica ou física".

O entendimento pessoal deste Relator é no sentido de que as precárias condições de higiene que a reclamada ofereceu aos seus empregados, especialmente nas barracas sanitárias, justificaria o pedido de indenização por danos morais. Afinal, se a empresa recruta trabalhadores para lhe prestarem serviços em local distante, deve cercar-se de vários cuidados, assegurando-se de que aos seus empregados serão disponibilizadas condições mínimas de higiene, saúde, segurança, conforto e alimentação. Neste sentido, erigiu-se a NR-31 (Norma Regulamentadora de Segurança e Saúde no Trabalho na Agricultura, Pecuária, Silvicultura, Exploração Florestal e Aquicultura).

Todavia, tendo em vista as condições rústicas inerentes ao ambiente de trabalho rural, os demais Desembargadores integrantes desta Câmara firmaram entendimento 
contrário, no sentido de que deve ser considerada como excludente da culpa patronal a notória dificuldade da empregadora de proporcionar instalações sanitárias satisfatórias e refeitórios adequados, ante as peculiaridades do trabalho no campo, em locais variáveis.

Neste sentido, já decidiu esta E. Câmara Julgadora, no Processo nº 000071219.2010.5.15.0156, em voto da lavra do Exmo. Desembargador MANUEL SOARES FERREIRA CARRADITA, cuja fundamentação, com a devida vênia, ora adoto como razões de decidir:

"Primeiramente, não podemos ignorar que o reclamante era cortador de cana e, portanto, trabalhava no campo, não na cidade, nem num escritório ou num centro de compras conhecido popularmente como 'shopping center'. É do conhecimento geral que o ambiente de trabalho no campo é rude por natureza, até pela dificuldade de se criarem condições mais sofisticadas de vida, fato que já faz parte da cultura de quem ali trabalha, como era o caso do reclamante, não significando isto que o ambiente seja insalubre ou inóspito. Não se pode esperar e nem seria possível ao empregador rural construir ao lado de cada lavoura um banheiro impecavelmente limpo e perfumado como o de um hotel cinco estrelas. Há muitos anos, quando este relator trabalhou no campo e mais tarde, quando, antes de ingressar na magistratura, foi advogado de sindicato de trabalhadores rurais, sequer existiam banheiros na roça!"

Assim, em que pesem os dissabores e desconfortos sofridos pelos trabalhadores no ambiente rural, não emerge dano moral indenizável. A ofensa moral não decorre dos atos ordinários do cotidiano, mas sim, das condutas excepcionais que revestidas de máfé impliquem sofrimento moral. Esta não é a hipótese dos autos.

No caso, por não restar evidenciada a intencional exposição do autor a situação vexatória que lhe ocasionasse o desrespeito necessário para a configuração do dano moral, não há falar-se em pagamento de indenização sob tal título.

Ressalte-se que nos processos $n^{\circ} 0003045-41.2010 .5 .15 .0156$ e $n^{\circ} 0002803-$ 
82.2010.5.15.0156, que possuem a mesma reclamada destes autos, essa E. Turma decidiu neste mesmo sentido.

Provejo.

Em face da improcedência da ação, resta prejudicada a apreciação das demais irresignações ofertadas pela reclamada, assim como a análise do recurso obreiro.

Diante do exposto, decido conhecer dos recursos ordinários interpostos pelo reclamante RAILTON DE SOUSA SANTOS e pela reclamada LDC-SEV

BIOENERGIA S.A. e prover em parte o recurso patronal para: 1) excluir a condenação ao pagamento da indenização de $20 \%$ sobre o valor da causa, por litigância de má-fé, arbitrada pela decisão de fls. 225/226; e 2) excluir a indenização por danos morais, tornando a reclamatória improcedente; resta, em face disso, prejudicada a apreciação das demais irresignações ofertadas pela reclamada, assim como a análise do recurso obreiro, tudo nos termos da fundamentação.

Custas em reversão, a cargo do reclamante, de cujo recolhimento fica isento, porquanto beneficiário da justiça gratuita (fls. 221).

\section{LUIZ ROBERTO NUNES}

\section{Relator}

